\title{
Enzymatic Synthesis of Polyesters: a QM/MM study
}

\author{
Pedro R. Figueiredo ${ }^{[\mathrm{a}, \mathrm{d}]}$, Beatriz C. Almeida ${ }^{[\mathrm{a}, \mathrm{d}]}$, Daniel F.A.R. Dourado ${ }^{[\mathrm{b}]}$, Andreia F. Sousa ${ }^{[\mathrm{c}]}$, Armando \\ J. D. Silvestre ${ }^{[\mathrm{c}]}$, Alexandra T. P. Carvalho ${ }^{[\mathrm{a}]^{*}}$
}

\begin{abstract}
Modern society is heavily reliant on synthetic polymers, commonly known as plastics; however plastic pollution is causing immeasurable damage to marine and land ecosystems. Better alternatives are actively being sought-after, such as biodegradable polyesters obtained by enzymatic synthesis. However, wild type enzymes still pose fundamental efficiency limitations. Protein reengineering approaches can circumvent those building up highly specific, selective and thermostable variants. Here we compare in detail the catalytic mechanisms for poly(caprolactone) synthesis by the wild type enzymes Archaeoglobus fulgidus carboxylesterase (AfEST) and Candida antarctica lipase B (CalB) by performing Quantum mechanics calculations and Quantum Mechanics/Molecular Mechanics Molecular Dynamics simulations. We found that bond-forming/breaking events are concerted with a proton transfer to or from the catalytic histidine in all the transition states, but with different degrees of coupling between the motions of the atoms involved. Our results give important insights towards the design of enzyme variants combining good activity with high thermostability in the synthesis of poly(caprolactone), which due to its biodegradability, biocompatibility and permeability characteristics is of great importance for biomedical applications, such as protein delivery, tissue engineering, gene delivery, orthopedic devices and resorbable sutures.
\end{abstract}

Keywords: Biodegradable polyesters, poly(caprolactone), enzymatic synthesis, carboxylesterase, AfEST, lipase, CalB, QM/MM MD simulations

\section{INTRODUCTION}

Synthetic polymers are extensively used by industry and technologies such as in packaging, textiles, electronic devices, machinery, pharmacy and medicine as highly advanced materials. ${ }^{1}$ However, in the last years, ecological concerns have stimulated the search for better alternatives to commodity plastics, especially because most of these polymers are non-biodegradable, persisting on the environment. There is, thus, a great urgency to find more sustainable alternatives, since plastic pollution is endangering ecosystems. ${ }^{2}$ Precisely, due to the non-biodegradability of conventional commercial polymers like poly(propylene) and poly(ethylene), the aliphatic-family of polyesters have been in the spotlight due to their ability to biodegrade in a reasonable time-scale. ${ }^{3}$ Among aliphatic polyesters, poly(caprolactone) (PCL) deserves a special focus for its biodegradability, biocompatibility, and permeability, meaning that PCL is a good candidate for biomedical applications, such as protein delivery, tissue engineering, gene delivery, orthopedic devices, and resorbable sutures. ${ }^{4-7}$ However, widespread commercialization of PCL is hampered due to synthesis and production issues, together with related economic obstacles, although the thermoplastic supply and demand of biodegradables are on high ${ }^{8}$ and PCL could be fuelled up.

[a] CNC - Center for Neuroscience and Cell Biology, Institute for Interdisciplinary Research (IIIUC), University of Coimbra, 3004-504 Coimbra, Portugal

${ }^{[b]}$ Almac Sciences, Department of Biocatalysis and Isotope Chemistry, Almac House, 20 Seagoe Industrial Estate, Craigavon, BT63 5QD, Northern Ireland UK

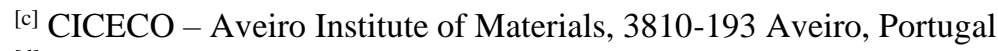

[d] Contributed equally

* atpcarvalho@uc.pt, www.atpcarvalho.pt 
Synthesis of polyesters (e.g. PCL), can be performed mainly by two distinct mechanisms: (i) polycondensation polymerization and (ii) ring-opening polymerization (ROP). ${ }^{3}$ The polycondensation mechanism has major drawbacks such as high temperatures and long reaction times that favour unwanted side reactions. The reactions are also limited to equilibrium requering water to be removed from the medium. ${ }^{9}$ But in the case of reactions performed by ROP, they can be highly efficient because no by-products, such as alcohols, are produced and no substrates need to be activated. This is a significant advantage over polycondensation polymerization both from a green chemistry perspective due to the atom-efficiency, but also because yields and molecular weights are favored. ${ }^{10,11}$ Aiming to achieve the desired polymer properties, the ROP mechanism has been continuously refined over the years. ${ }^{1}$ Several combinations of initiators and catalysts have been evaluated for ROP synthesis, and enzyme-catalysed ROP was considered one of the most promising approaches. ${ }^{10,12,13}$ When compared to conventional chemical routes, enzymatic catalysis gives a more precise construction of welldefined structures, such as high control of enantio-, chemo-, regio-, stereo- and choro-selectivity. More important, enzymes are recyclable, eco-friendly, usually do not require the use of toxic reagents, and avoid the problems associated with trace residues of metallic catalysts. ${ }^{11,14}$

Several lipases (EC 3.1.1.3) and some carboxylesterases (EC 3.1.1.1) have been employed to produce polyesters over different ROP conditions, yielding polymers with a vast array of molecular weights (Mw). ${ }^{12,15}$ Among lipases, the immobilized lipase B from Candida antarctica $(\mathrm{CalB})$ is one of the most studied. ${ }^{15-19}$ Although this enzyme is able to synthesize, in some instances, polyesters with relatively high molecular weights and good yields ${ }^{20,21}$ (including PCL), in most cases the polymers have low molecular weights. ${ }^{22,23}$ Other factors that limit the industrial application of these enzymes are: (i) the low activity and selectivity for some monomers; (ii) unfavourable compatibility in chemoenzymatic reactions; (iii) low stability under harsh reactions conditions. ${ }^{24}$ Regarding the last point, although CalB immobilization increases the stability and reusability of the enzyme, the immobilized enzyme still displays maximum activity at $40{ }^{\circ} \mathrm{C}$ with substantial activity drop at higher temperatures for some substrates. ${ }^{18}$ Even when higher catalytic activities are obtained with temperatures in range of $60-80{ }^{\circ} \mathrm{C}$, which happens for many substrates and in low-polarity solvents, ${ }^{25}$ higher molecular weight polymers are frequently produced at lower reaction temperatures $\left(40{ }^{\circ} \mathrm{C}, 45^{\circ} \mathrm{C}\right) .{ }^{18,26,27} \mathrm{Hence}$, the severe conditions required at the industrial scale can compromise catalysis.

However, rational protein engineering approaches can be employed to address these limitations and expand the scope of enzymes for polyester synthesis by ROP. ${ }^{26-28}$ Particularly good starting points for enzyme design are enzymes from thermophiles, which have been recognized as potential catalysts in various biotechnology applications. ${ }^{29-32}$ The thermophilic esterase from the hyperthermophilic archaeon Archaeoglobus fulgidus (AfEST) was previously tested for the synthesis of the aliphatic polyester PCL in various organic solvents and solvent-free systems. ${ }^{33-36}$ The free form of the enzyme (at a concentration of $25 \mathrm{mg} / \mathrm{ml}$ ), catalyses the formation of polymer chains with a number-average molecular weight (Mn) of $1400 \mathrm{~g} / \mathrm{mol}$ and with a monomer conversion of almost $100 \%$, in toluene at $80{ }^{\circ} \mathrm{C}$ for $72 \mathrm{~h} .{ }^{35}$ On the other hand, the immobilized form of the enzyme $(80 \mathrm{mg})$, achieves the production of polymer chains with molecular mass (Mn) of $1160 \mathrm{~g} / \mathrm{mol}$ and monomer conversion of $100 \%$, in the same conditions. ${ }^{36} \mathrm{Meaning}$, that the immobilization process in AfEST does not necessarily produce polymers with higher molecular weights.

Considering PCL as a case-study for aliphatic polyesters synthesis, here, we draw lessons from how CalB and AfEST differently achieve PCL synthesis in the quest to obtain enzymes able to match high conversion with high thermostability. We compare in detail, the catalytic mechanisms of the wild type enzymes by performing Quantum Mechanics/Molecular Mechanics (QM/MM) Molecular Dynamics (MD) simulations and Quantum Mechanics (QM) calculations. 


\section{METHODS}

\section{Initial Setup and Classical Molecular Dynamics}

The initial structures were modelled from CalB (5A71 ${ }^{37}, 0.91 \AA$ resolution) and AfEST ( $1 \mathrm{JJJ}^{38}, 2.20 \AA ̊$ resolution) crystal structures, and the protonation states assigned with MolProbity. ${ }^{39}$ The reactants (RC), intermediates (INT-1, enzyme activated monomer - EAM and INT-2) and products (PC) were geometry optimized in Gaussian09 ${ }^{40}$ using B3LYP ${ }^{41}$ with the 6-31G(d) basis sets and a Polarizable Continuum Model (PCM) ${ }^{42}$ solvent description. Atomic partial charges were calculated resorting to the Restrained Electrostatic Potential (RESP) ${ }^{43}$ method from the HF/6-31G(d) single-point energy calculations. The initial position of $\varepsilon$-caprolactone $(\varepsilon-\mathrm{Cl})$ was obtained by molecular docking. The MD simulations of all intermediates in the reaction profiles were performed using the Amber molecular dynamics program (AMBER18) ${ }^{44}$ with the parm99SB ${ }^{45}$ and $\mathrm{GAFF}^{46}$ force fields. All the minima in the catalytic cycle were subjected to $20 \mathrm{~ns}$ triplicate simulations with different initial velocities, for a total combined time of $60 \mathrm{~ns}$. Reference structures were calculated for all simulations, based on the structure with the lowest root-mean-square deviation (RMSD) to the average of the simulation. ${ }^{47}$ More information can be found in the Supporting information (SI) - Material and Methods.

\section{Quantum Mechanical/Molecular Mechanical (QM/MM) Calculations}

The QM/MM calculations ${ }^{48,49}$ were performed using the internal semi-empirical hybrid QM/MM functionality implemented in AMBER $18^{44}$ with periodic boundary conditions. The initial structures for the calculations were the lowest root-mean-square-deviation structures to the average of the MD simulations of the stationary points. The PM6 $6^{50,51}$ semi-empirical method was employed for the high-level layer and the MM region was described by the Amber parm99SB force field. ${ }^{45}$ The reactions were conducted at the optimum temperature for each enzyme ( $318.15 \mathrm{~K}$ for CalB and 353.15 K for AfEST). Corrections were later applied to the obtained PM6 potentials of mean force (PMFs) by performing geometry optimizations of the high-level layer models with the exchangecorrelation functional of 6-31G(,d) basis set for B3LYP ${ }^{41}$ with Grimme D3 dispersion ${ }^{52}$, M06-2X $\mathrm{X}^{53}$ and $w \mathrm{~B} 97 \mathrm{XD}^{54}$, according to Carvalho et al. and Bowman et al. ${ }^{55,56}$ More details and the coordinates for these structures are provided in SI.

Electrostatic embedding ${ }^{57}$ was employed and the boundary treated via the link atom approach. Long-range electrostatic interactions were described by an adapted implementation of the Particle Mesh Ewald (PME) method for QM/MM. ${ }^{58}$
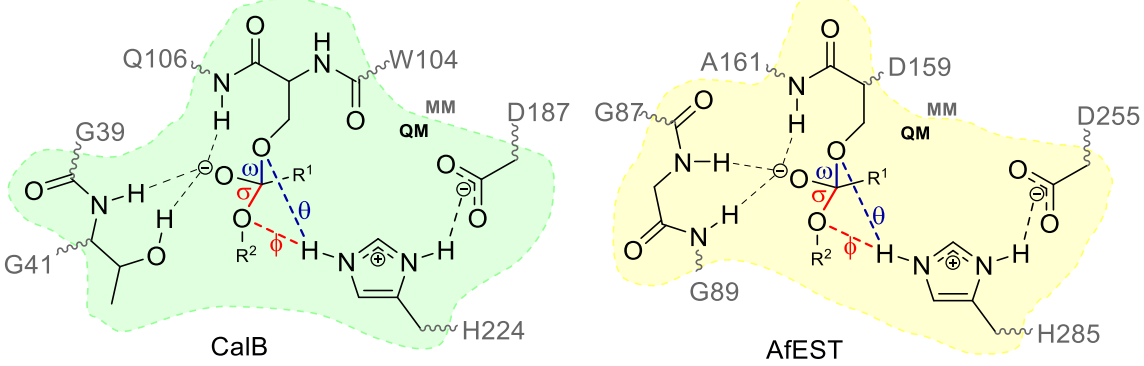

Scheme 1. Representation of the QM region and the corresponding link atoms. INT-1 R $\mathrm{R}^{1}=\left(\mathrm{CH}_{2}\right)_{5}-\mathrm{R}^{2}$. INT-2 R $\mathrm{R}^{1}=\left(\mathrm{CH}_{2}\right)_{5}-\mathrm{OH}, \mathrm{R}^{2}=\left(\mathrm{CH}_{2}\right)_{5}-\mathrm{CO}_{2} \mathrm{H}$.

The high-level layer in the reactants complex (RC) for CalB include the $\varepsilon$-caprolactone, S105, the side chains of H224, D187 and T40 and the backbone of Q106 and T40 residues. For AfEST besides the $\varepsilon$-caprolactone and S160, the high-level layer also includes the side chains of H285, D255 and the backbone of G88, G89 and A161 residues (Scheme 1). The total charge of the high-level layer was -1 for both systems. The total number of atoms in the high-level layer in the reactants is 67 for CalB and 63 for AfEST. For the other intermediates, the high-level layer includes the same protein residues plus either the INT-1, EAM, INT-2 or the PCL model compound. 
The potential energy scans of the initial structures (INT-1 and INT-2) were performed along a suitable chosen reaction coordinate restrained in $0.1 \AA$ steps using the umbrella sampling method, except near the transition states were smaller steps of $0.02 \AA$ were employed (Detailed information can be found in the information in SI). The PMFs were computed resorting to the Weighted Histogram Analysis Method (WHAM). ${ }^{59}$

The cluster model transition states where also calculated (with the exchange-correlation functional B3LYP) and vibrational frequency calculations and intrinsic reaction coordinates (IRC) path following were carried out to confirm them.

Unless otherwise stated, all energy values mentioned in the text of this manuscript are given with respect to the PMF corrected with B3LYP/6-31G(d) with Grimme D3 dispersion.

\section{RESULTS AND DISCUSSION}

\section{Catalytic Mechanisms of the Wild-type Enzymes}

It is well-known that the enzymes CalB and AfEST display the classical $\alpha / \beta$ hydrolase fold, dimer arrangement and Ser-His-Asp catalytic triad ${ }^{60,61}$ (Figure 1). Yet, they are structurally quite distinct. AfEST has a cap domain composed of five helices from two separate regions (residues 1-54 and 188-246), ${ }^{38}$ while CalB lacks this structure and has two highly mobile short $\alpha$-helixes, helix $\alpha 5$ (residues 142-146) and helix $\alpha 10$ (residues 268-287), where the former acts as the putative lid. ${ }^{37,62}$ Furthermore, both enzymes display two pockets, an acyl-binding pocket, and a secondary alcohol-binding pocket, with different sizes and orientations ${ }^{37,38}$. The pockets of CalB display a total volume of $204.6 \AA^{3}$, while the AfEST pockets have an overall volume of $343.5 \AA^{3} .^{63-65}$ The CalB catalytic triad is composed of residues S105-H224-D187, which is located close to the putative lid. ${ }^{37,60,62}$ AfEST has the catalytic triad S160$\mathrm{H} 285-\mathrm{D} 255$ and is located at the interface between the classical $\alpha / \beta$ hydrolase fold and the cap domain. ${ }^{38}$ The stated serine act as nucleophiles and the histidine as an acid/base (transferring protons between the catalytic serine and the substrate) that are stabilized by the aspartate residues. ${ }^{11,66,67}$ The enzymes also have a region called the oxyanion hole, where a particular spatial arrangement of hydrogen bond donors stabilizes the negative charge that is developed on the oxygen atom of the tetrahedral intermediate structures that are formed during the catalytic mechanism. ${ }^{67,68}$ For CalB, the hydrogen bond donors are the backbone amides of T40 and Q106 and the side-chain hydroxyl group of T40, ${ }^{69}$ while for AfEST the hydrogen bond donors are the backbone amides of G88, G89 and A161 38 (Figure 1).

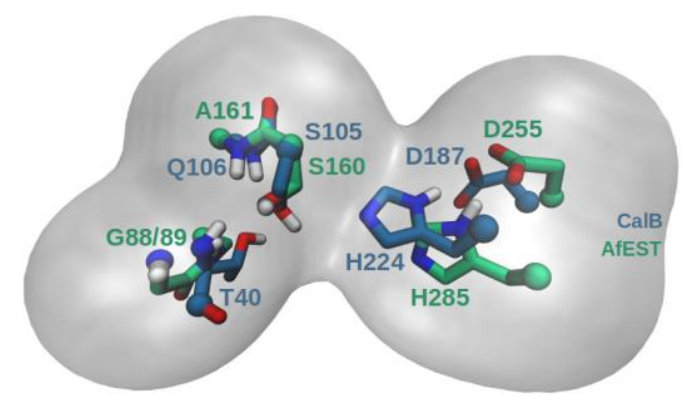

Figure 1. Catalytic triad and oxyanion hole residues of CalB and AfEST.

The first half part of the catalytic cycle or acylation step (Scheme 2), concerns the nucleophilic attack of the serine side-chain oxygen $\left(\mathrm{O}_{\mathrm{Ser}}\right)$ on the carbonyl carbon of the $\boldsymbol{\varepsilon}-\mathbf{C l}$ substrate, which occurs concomitantly with proton transfer from the $\mathrm{O}_{\text {Ser }}$ to the histidine residue forming the first tetrahedral intermediate structure (INT-1).$^{70}$ In the INT-1 structure, the histidine residue is positively charged and stabilized by the aspartate residue. 


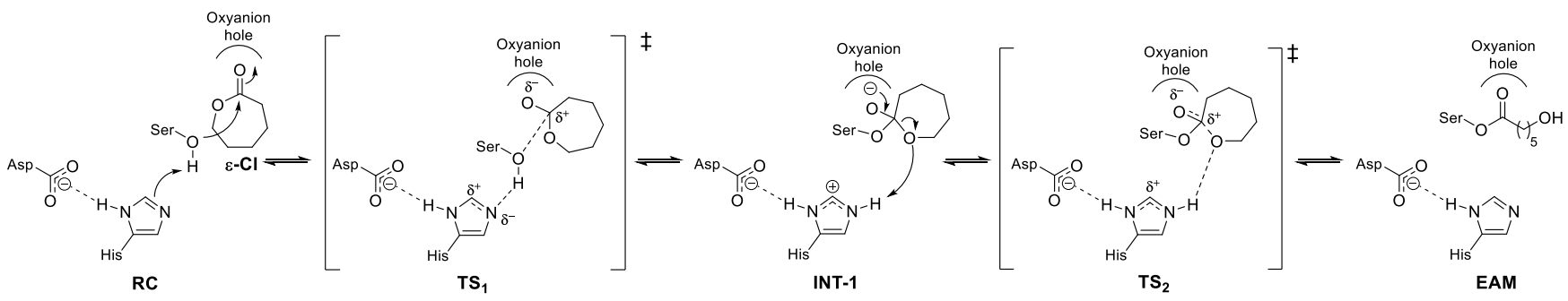

Scheme 2. First half part mechanism for the CalB and AfEST enzymatic synthesis of PCL.

For CalB, the $\boldsymbol{\varepsilon}-\mathbf{C l}$ substrate binds weakly to its active site pocket as is reflected in the high value of $\mathrm{K}_{\mathrm{M}}$ of $0.72 \mathrm{M}{ }^{71}$ Accordingly, in the MD simulations we can see that the $\mathbf{\varepsilon}$-Cl substrate is significantly mobile during the simulations, with the distance between it and the catalytic serine ranging between $3.22 \pm 2.30 \AA$ and $9.76 \pm 0.81 \AA$ (Figure S1). Consequently, we resorted to model the INT-1 as our initial structure, which is in accordance with previous studies. ${ }^{72}$ Despite the large distance to the serine residue, we can observe in two replicas, that the carbonyl oxygen of the $\mathbf{\varepsilon}-\mathbf{C l}$ substrate establishes a hydrogen bond with the side-chain hydroxyl of the oxyanion-hole residue T40 (Figure 2A). The nucleophilic attack proceeds via the formation of a first transition state structure (TS $\mathbf{1}$ ), which has a free energy barrier $\left(\Delta G^{\ddagger}\right)$ of $6.0 \pm 0.1 \mathrm{kcal} / \mathrm{mol}$ (Figure 3A) generating the INT-1 (Figure 2B).

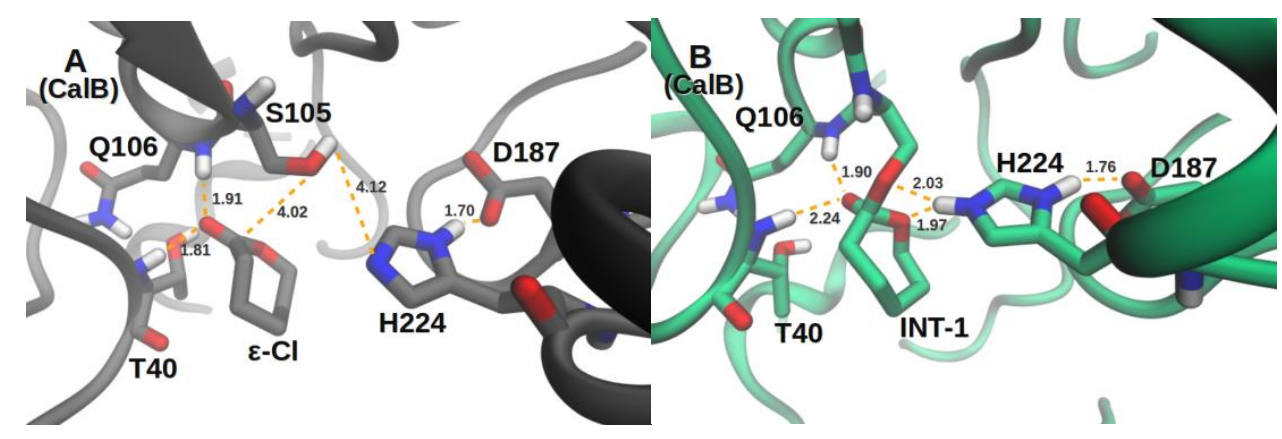

Figure 2. CalB active site pocket: A) $\boldsymbol{\varepsilon}$-Cl substrate in the RC structure; B) INT-1 structure.

As previously reported, the $\mathbf{T S}_{\mathbf{1}}$ and all other transition states in this catalytic cycle are concerted ${ }^{73,74}$, meaning that bond making/breaking events occur simultaneously with a proton transfer to or from the histidine. In INT-1 the backbone amide groups of the oxyanion hole Q106 and T40 stabilize the developing negative charge on the substrate oxygen atom $\left(\mathrm{O}_{\text {oxy }}\right)(1.90 \pm 0.12 \AA$ and $2.24 \pm 0.32 \AA$, respectively, Figure $2 \mathrm{~B}$ ). This structure has a $\Delta \mathrm{G}$ of $-1.1 \pm 0.1 \mathrm{kcal} / \mathrm{mol}$ (Figure $3 \mathrm{~A}$ ). The $\mathrm{HE}$ atom of $\mathrm{H} 224 \mathrm{is} 1.97 \pm$ $0.24 \AA$ from the oxygen atom of the $\mathbf{\varepsilon}-\mathbf{C l}$ substrate $\left(\mathrm{O}_{\text {lac }}\right)$ in the reference structure (Figure $\left.2 \mathrm{~B}\right)$. For the AfEST simulations, we observe less variation in the position of $\boldsymbol{\varepsilon}$-Cl substrate (Figure 4A and Figure S2), which is also in accordance with the reported $\mathrm{K}_{\mathrm{M}}$ of $0.093 \mathrm{M}^{35}$ (7.7 fold lower than the one for $\mathrm{CalB}$ ). The $\mathrm{O}_{\text {oxy }}$ atom makes a hydrogen bond with the backbone amide group of residue G89 (1.96 $\pm 0.84 \AA$, away in the reference structure, Figure 4A). Although the combined size of the pockets is substantially larger in AfEST than in CalB,${ }^{70}$ the $\mathbf{\varepsilon}-\mathbf{C l}$ substrate makes more interactions in AfEST because of its higher hydrophobic nature. ${ }^{35}$ The formation of the INT-1 from the RC, proceeds via the $\mathbf{T S}_{\mathbf{1}}$ with a $\Delta G^{\ddagger}$ of $9.8 \pm 0.1 \mathrm{kcal} / \mathrm{mol}$ (Figure $3 \mathrm{~B}$ ). We also tested the proton transfer step in a stepwise mechanism. In this case, the serine proton is transferred to the histidine, while the substrate is not correctly positioned for the nucleophilic attack. The barrier associated with this step amounted to $37.0 \mathrm{kcal} / \mathrm{mol}$ (with the PM6 semi-empirical method,

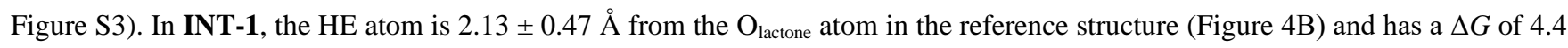
$\pm 0.1 \mathrm{kcal} / \mathrm{mol}$ (Figure 3B). The amide groups of G88, G89, and A161 make hydrogen bonds with the $\mathrm{O}_{\text {oxy }}$ atom (distances of $2.28 \pm$ $0.52 \AA, 1.70 \pm 0.13 \AA$ and $1.95 \pm 0.23 \AA$, respectively), stabilizing the negative charge that has developed in this atom. Furthermore, 
the oxygen atoms of D255 interchangeably make hydrogen bonds with the HD atom of the positively charged H285 during the simulations $(2.01 \pm 0.67 \AA$, Figure 4B). This interaction highlights the importance of an aspartate residue in the stabilization of the histidine residue.
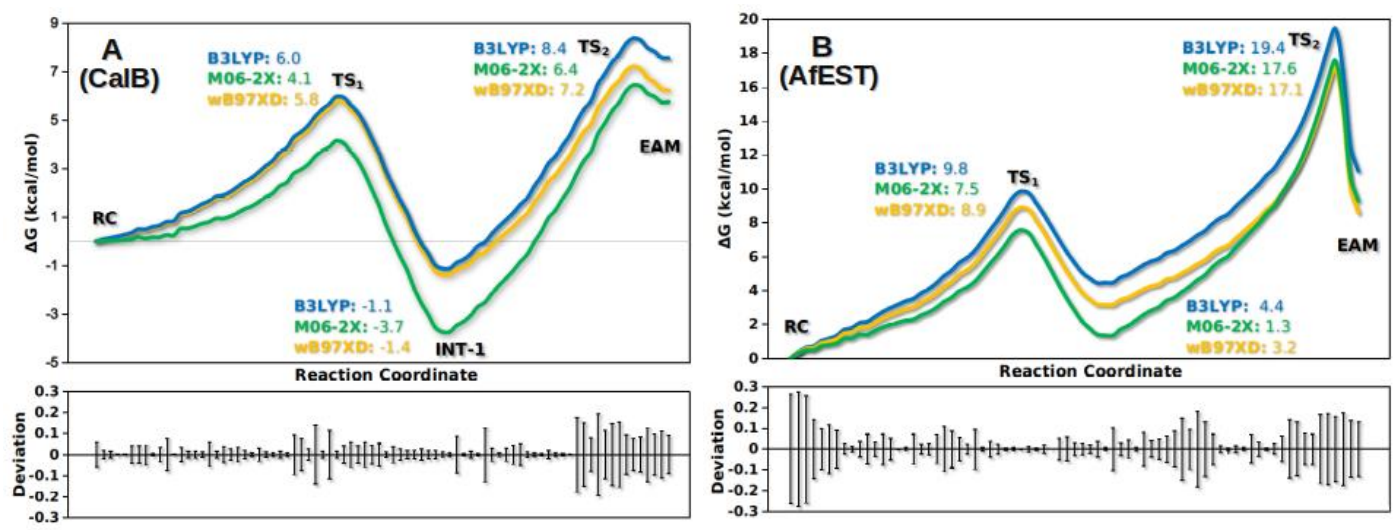

Figure 3. Calculated PMFs for the formation of the EAM structure - acylation step - with A) CalB and B) AfEST. Each line denotes the corrected free energies calculated with different theory levels and the statistical uncertainty panel related to the PMF energies. More information can be found in Figures S4 and S5.

The INT-1 is then converted into the EAM by ring-opening and assisted by proton transfer from the histidine residue. In CalB, the second transition state structure $\left(\mathbf{T S}_{2}\right)$ is $8.4 \pm 0.1 \mathrm{kcal} / \mathrm{mol}$ above the reactants and the overall $\Delta \mathrm{G}^{\ddagger}$ for this step is $9.5 \mathrm{kcal} / \mathrm{mol}(\mathrm{Figure}$ 3A). For AfEST, the $\mathbf{T S} \mathbf{S}_{2}$ has an overall $\Delta G^{\ddagger}$ of $19.4 \pm 0.2 \mathrm{kcal} / \mathrm{mol}$ for the ring-opening (Figure 3B).

For both enzymes the $\mathbf{T S}_{\mathbf{2}}$ show the highest calculated free energy values (including the deacylation steps, that we will detail further in the text). Consequently, the rate-determining step for the enzymatic synthesis of PCL is the formation of the EAM, which is in accordance with previous studies. ${ }^{75,76}$ According to Eyring's equation, ${ }^{77}$ for CalB, the reported turnover number $\left(k_{\mathrm{cat}}\right)$ of $72.9 \mathrm{~s}^{-1}$ for the immobilized form, corresponds to a free energy of about $15.0 \mathrm{kcal} / \mathrm{mol}$ at $45{ }^{\circ} \mathrm{C},{ }^{71}$ as for AfEST, the $k_{\text {cat }}$ of $0.064 \mathrm{~s}^{-1}$ corresponds to a $\Delta G^{\ddagger}$ of $22.7 \mathrm{kcal} / \mathrm{mol}$ at $80{ }^{\circ} \mathrm{C} .{ }^{35}$ Our calculated barrier of $19.4 \pm 0.2 \mathrm{kcal} / \mathrm{mol}$ (Figure $3 \mathrm{~B}$ ) for ring-opening is thus in good agreement with experimental data. For CalB only $k_{\text {cat }}$ for the imobilized enzyme is available, although we cannot directly compare this value with the free enzyme, the values are in agreement.

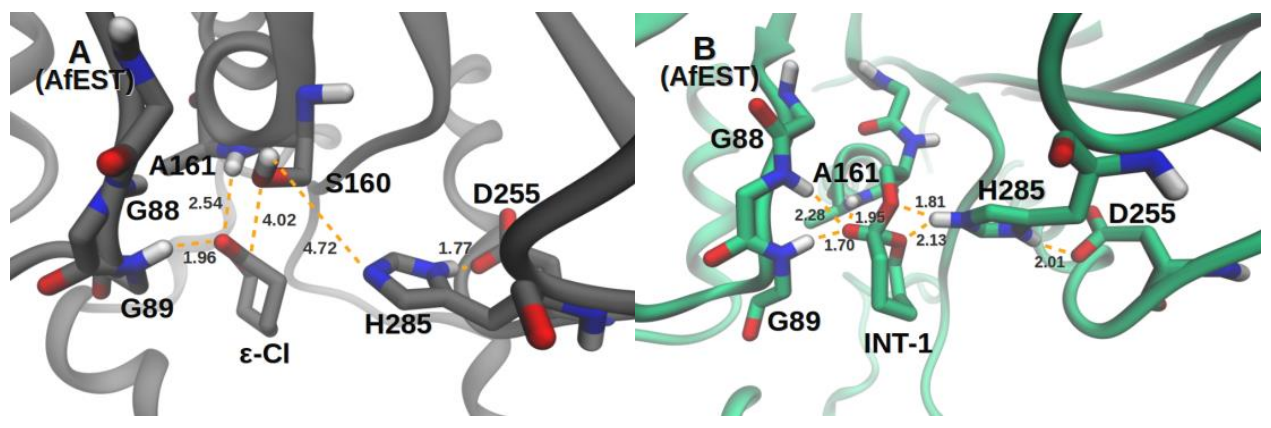

Figure 4. AfEST active site pocket: A) $\boldsymbol{\varepsilon}$-Cl substrate in the RC structure; B) INT-1 structure.

The orientation of the histidine/aspartate residues in the INT-1 and connected transition states (TS 1 and $\left.\mathbf{T S}_{\mathbf{2}}\right)$ in the PMFs and in the small cluster models (Figure 2B, Figure 4B andFigure 5) offer an explanation for the enzymes energy differences. As mentioned before, all transition states are concerted, with bond making/breaking events occurring simultaneously with a proton transfer to or from the histidine. In the INT-1 of AfEST, the HE atom of the $\mathrm{H} 285$ residue is closer to the $\mathrm{O}_{\text {Ser }}$ atom than to the $\mathrm{O}_{\text {lac }}$ atom $(1.85 \AA$ and $3.42 \AA$, respectively, Figure 5). 


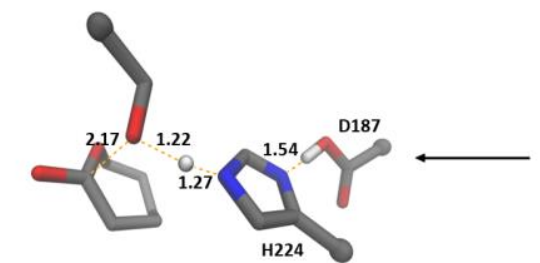

$\mathrm{TS}_{1}$

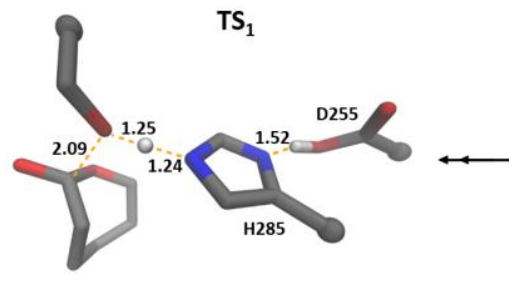

$\mathrm{TS}_{1}$

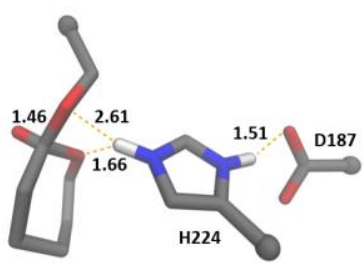

INT-1

(CalB)

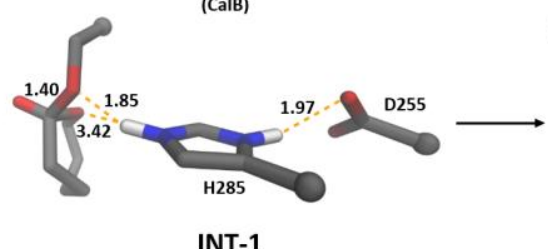

INT-1

(AfEST)

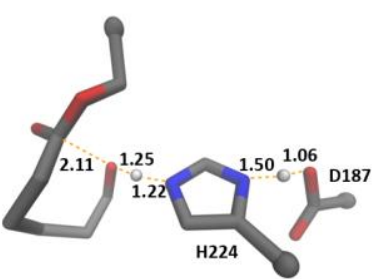

$\mathrm{TS}_{2}$

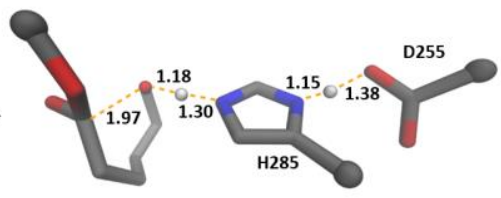

$\mathrm{TS}_{2}$

Figure 5. Scheme of the cluster model structures of $\mathbf{T S} \mathbf{S}_{\mathbf{1}}$, INT-1 and $\mathbf{T S}_{\mathbf{2}}$ for CalB and AfEST (here, for simplicity, the oxyanion residues were deleted). The same trend observed in the full models is kept in these small models: In INT-1 the distance from the histidine proton to $\mathrm{O}_{\text {lac }}$ is smaller for CalB, favouring the forward reaction, whereas in AfEST the distance to $\mathrm{O}_{\text {Ser }}$ is smaller.

This geometry favours the coupling of vibration motions of the proton transfer to $\mathrm{O}_{\text {Ser }}$ with bond making to the lactone. In fact, $\mathbf{T S}_{\mathbf{1}}$ and INT-1 are close in energy, favouring the reverse reaction (to $\mathbf{T S}_{\mathbf{1}}$ ). In opposition, in CalB the HE atom of H224 is closer to the $\mathrm{O}_{\text {lac }}$ atom than the $\mathrm{O}_{\text {Ser }}$ atom $(1.66 \AA$ and $2.71 \AA$, respectively, Figure 5). This leads to a later and higher energy transition state, when going in the reverse direction and much less displacement of the histidine proton in the forward direction (to EAM), facilitating concomitant proton transfer and lactone opening, decreasing the overall free energy barrier. Consequently, in CalB the active site arrangement is such that it further promotes $\mathrm{O}_{\mathrm{lac}}$ leaving, lowering the $\mathbf{T} \mathbf{S}_{\mathbf{2}}$ barrier. On the other hand, in AfEST, the active site arrangement promotes $\mathrm{O}_{\text {Ser }}$ leaving, making the INT-1 to TS $_{\mathbf{1}}$ backward free energy barrier lower and the overall $\Delta G^{\neq}$is much higher. To further show this, we ran a simulation in which the histidine residue of CalB is in a position similar to the one observed in AfEST. In this simulation, the energy decreases by $4.2 \pm 0.1 \mathrm{kcal} / \mathrm{mol}$ (Figure S6) as the histidine moves closer to the $\mathrm{O}_{\text {lac }}$.

In the second half part of the catalytic cycle (Scheme 3), also called the deacylation step, the second tetrahedral intermediate structure (INT-2) is generated after nucleophilic attack by the oxygen atom of the alcohol moiety of a molecule of 6-hydroxycaproic acid (6HCA) to the carbonyl carbon atom of the EAM. The 6-HCA molecule is the initiator (init) for the polymerization reaction and was previously formed in a primary step, with the ring-opening of a molecule of $\boldsymbol{\varepsilon}-\mathbf{C l}$ and post product hydrolysis. ${ }^{70}$ The $\mathbf{P C L}$ product is formed concomitantly with proton transfer from the histidine to the serine residue, regenerating the free enzyme.

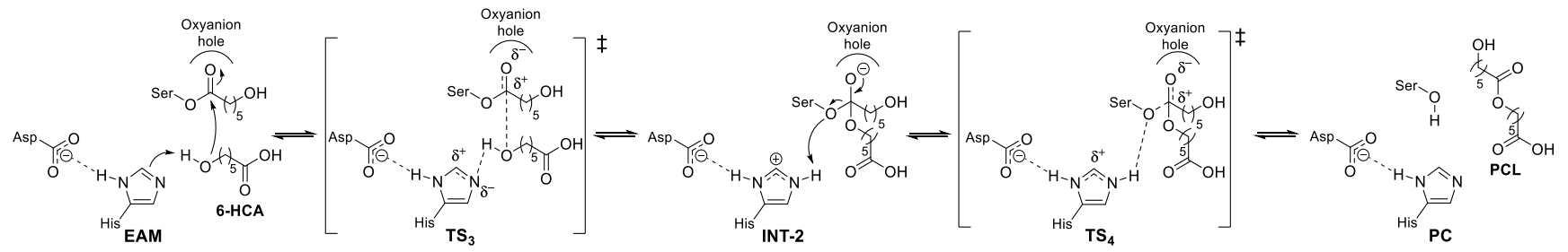

Scheme 3. Second half part mechanism for the CalB and AfEST enzymatic synthesis of PCL.

In the reaction catalysed by CalB, the average distance of the carbonyl carbon atom of EAM to the hydroxyl oxygen atom of 6-HCA molecule $\left(\mathrm{O}_{\text {init }}\right)$ is $4.83 \pm 0.69 \AA$ and the hydroxyl hydrogen atom of the 6-HCA molecule is $5.06 \pm 1.05 \AA$ away from the NE atom of H224 (Figure 6A and Figure S7). The INT-2 is generated via the third transition state structure $\left(\mathbf{T S}_{3}\right.$ ), which is $7.7 \pm 0.2 \mathrm{kcal} / \mathrm{mol}$ above the EAM (Figure 7A). The hydroxyl hydrogen atom is transferred from the 6-HCA molecule to the NE atom of H224, while 
in a concerted manner a bond is formed between the $\mathrm{O}_{\text {init }}$ and the carbonyl carbon of the EAM, generating the INT-2 $(1.4 \pm 0.1$ kcal/mol below the EAM, Figure 7B and Figure 7A). The reaction proceeds to the PCL product release, through the formation of the last transition state structure $\left(\mathbf{T S}_{\mathbf{4}}, 4.1 \mathrm{kcal} / \mathrm{mol}\right.$ above the INT-2, Figure 7A), regenerating the free enzyme that is now ready for another turnover (Figure 6C).

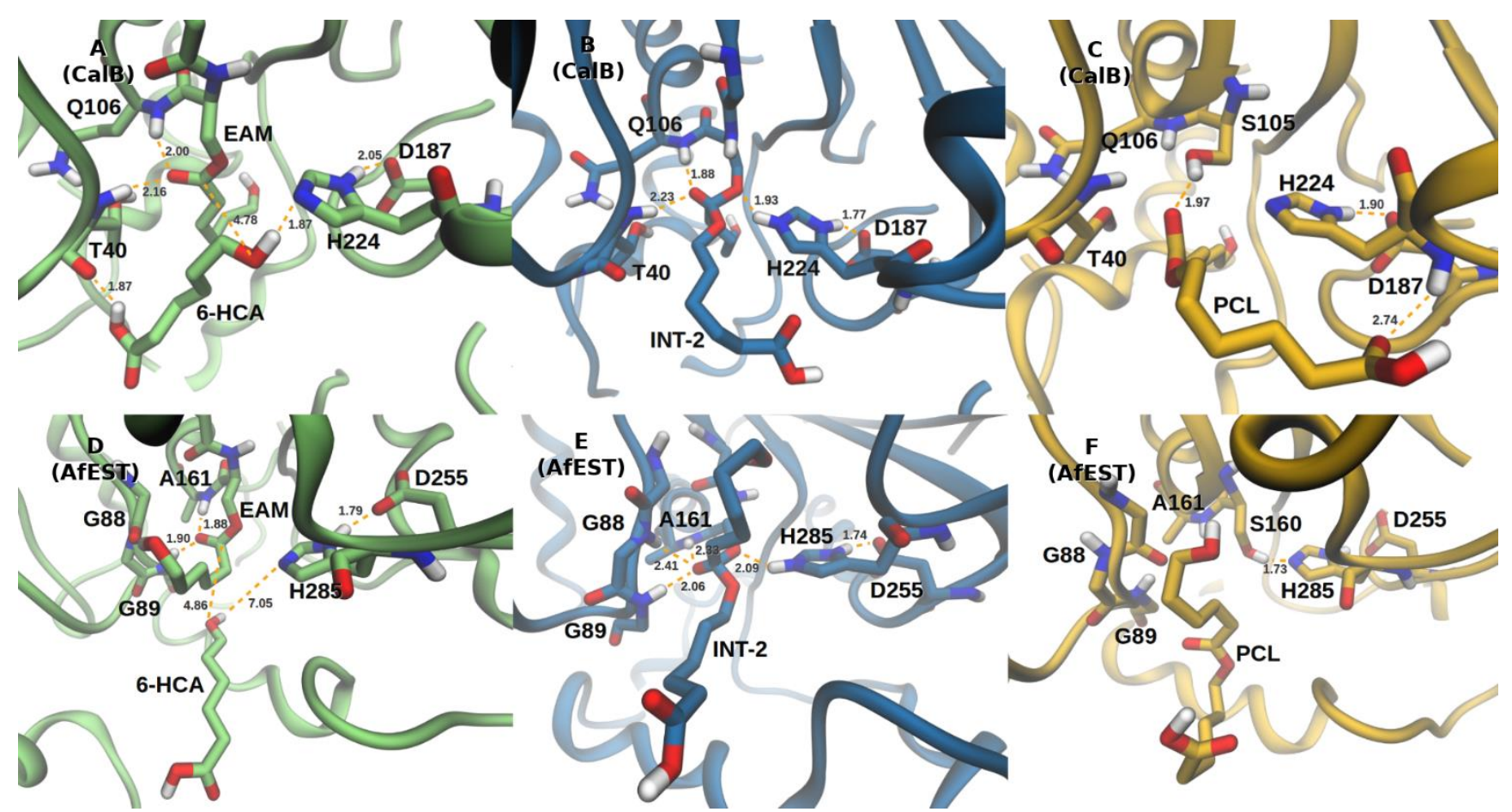

Figure 6. CalB and AfEST active site pockets, respectively: A and D) EAM structure with a 6-HCA molecule; B and E) INT-2 structure; C and F) Free enzyme with the PCL model compound.

In the reaction catalysed by AfEST, the 6-HCA molecule is in the medium pocket and the $\mathrm{O}_{\text {init }}$ atom of 6-HCA molecule $4.86 \pm 1.61$ $\AA ̊$ away from carbonyl carbon atom of the EAM (Figure 6D and Figure S8). Bond forming the initiator occurs simultaneously with proton transfer from the $\mathrm{HO}_{\text {init }}$ atom to $\mathrm{H} 285$, as it happens in CalB, with $5.1 \pm 0.1 \mathrm{kcal} / \mathrm{mol}$ (Figure $7 \mathrm{~B}$ ) being required to reach the TS 3 . The INT-2 (Figure 6E) is $10.2 \mathrm{kcal} / \mathrm{mol}$ below TS 3 and $5.1 \pm 0.1 \mathrm{kcal} / \mathrm{mol}$ below the EAM (Figure 7B). The PCL product is released after breakage of the $\mathrm{CO}_{\mathrm{Ser}}$ bond and proton transfer from $\mathrm{H} 285$ to the serine oxygen $(2.09 \pm 0.29 \AA$ away, Figure $6 \mathrm{~F})$. This step requires $4.0 \mathrm{kcal} / \mathrm{mol}$ (Figure 7B) and after PCL product release, the serine hydroxyl side-chain is regenerated.
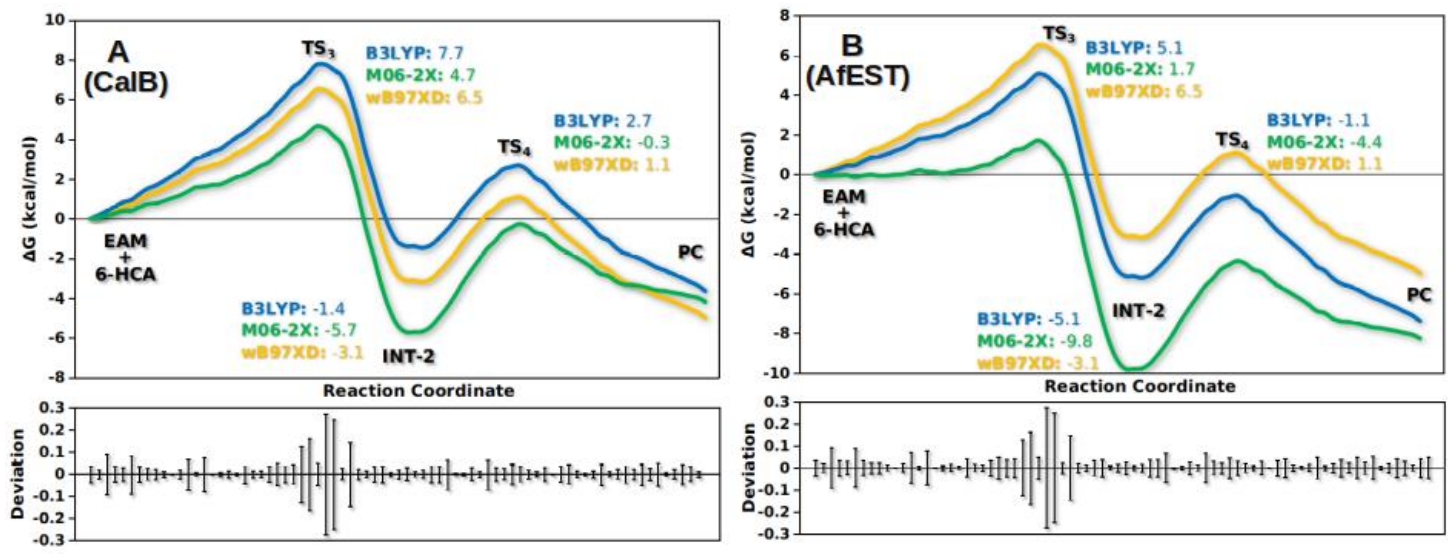

Figure 7. Calculated PMFs for the deacylation - PCL product release - with A) CalB and B) AfEST. Each line denotes the corrected free energies calculated with different theory levels and the statistical uncertainty panel related to the PMF energies. More information can be found in Figures S9 and S10. 


\section{CONCLUSIONS}

We have determined the catalytic mechanisms of the wild type CalB and AfEST enzymes by performing QM/MM and MD simulations. By determining the full catalytic cycles, we showed that the formation of the EAM structure is the rate-determining step when $\varepsilon$-caprolactone is the substrate, with the overall barrier for CalB $(9.5 \mathrm{kcal} / \mathrm{mol})$ significantly lower than the one for AfEST (19.4 $\mathrm{kcal} / \mathrm{mol}$ ), which is in accordance with the experimental data. ${ }^{35,71,75,76}$ Our results also show that the major differences between the enzymes occur exactly during the lactone ring-opening. By comparing the structures, we can observe that the different scaffolds of the enzymes, allow for different arrangements of the catalytic triad residues. Here we showed that these different geometries have important consequences in the way these enzymes convert $\boldsymbol{\varepsilon}$-Cl. Since the transition states are concerted (proton transfer occurs concomitantly with $\mathrm{CO}$ bond making/breaking), a smaller distance to $\mathrm{O}_{\mathrm{lac}}$ favours the coupling of the motions of proton transfer to $\mathrm{CO}_{\text {lac }}$ bond breaking. In opposition, a smaller distance to $\mathrm{O}_{\text {Ser }}$ favours the coupling of the motions of proton transfer to the $\mathrm{CO}_{\text {Ser }}$ bond. In accordance, the histidine in AfEST is significantly closer to $\mathrm{O}_{\text {Ser }}$ favouring transfer in an early transition state in the reverse direction, while in CalB the same proton is closer to the $\mathrm{O}_{\mathrm{lac}}$, resulting in the corresponding transition state in the reverse direction and significantly less atom displacement when going in the forward direction leading to a smaller overall free energy barrier.

These insights using PCL as a case-study, and CalB and AfEST to mediate esterification reactions, are useful for protein engineering approaches to tailor the enzymes for industrial important poly(esterification) reactions, especially those affording biodegradable aliphatic polyesters which are gaining momentum due to the search for more sustainable alternatives, since plastic pollution is endangering the environment.

\section{ACKNOWLEDGMENTS}

This work was financed by Portuguese national funds via FCT - Fundação para a Ciência e a Tecnologia, under project(s) MIT-Portugal (MIT-EXPL/ISF/0021/2017), the grant IF/01272/2015 and UID/NEU/04539/2019. The costs resulting from the FCT hiring of A.F.S. were funded by national funds (OE), through FCT - Fundação para a Ciência e a Tecnologia, I.P., in the scope of the framework contract foreseen in the numbers 4, 5 and 6 of the article 23 of the Decree-Law 57/2016 of August, changed by Law 57/2017 of 19 July. This work was developed within the scope of the project CICECO - Aveiro Institute of Materials, FCT Ref UID/CTM/50011/2019, financed by national funds through the FCT/MCTES.

\section{REFERENCES}

(1) Kobayashi, S.; Makino, A. Enzymatic Polymer Synthesis: An Opportunity for Green Polymer Chemistry. Chem. Rev. 2009, 109, 52885353.

(2) Geyer, R.; Jambeck, J. R.; Law, K. L. Production, Use, and Fate of All Plastics Ever Made. Science Advances 2017, 3 , e1700782.

(3) Vilela, C.; Sousa, A. F.; Fonseca, A. C.; Serra, A. C.; Coelho, J. F. J.; Freire, C. S. R.; Silvestre, A. J. D. The Quest for Sustainable Polyesters - Insights into the Future. Polym. Chem. 2014, 5, 3119-3141.

(4) Vert, M.; Li, S. M.; Spenlehauer, G.; Guerin, P. Bioresorbability and Biocompatibility of Aliphatic Polyesters. J Mater Sci: Mater Med $1992,3,432-446$.

(5) Seyednejad, H.; Ghassemi, A. H.; van Nostrum, C. F.; Vermonden, T.; Hennink, W. E. Functional Aliphatic Polyesters for Biomedical and Pharmaceutical Applications. Journal of Controlled Release 2011, 152, 168-176.

(6) Siddiqui, N.; Asawa, S.; Birru, B.; Baadhe, R.; Rao, S. PCL-Based Composite Scaffold Matrices for Tissue Engineering Applications. Molecular Biotechnology 2018, 60, 506-532. 
(7) Espinoza, S. M.; Patil, H. I.; San Martin Martinez, E.; Casañas Pimentel, R.; Ige, P. P. Poly-e-Caprolactone (PCL), a Promising Polymer for Pharmaceutical and Biomedical Applications: Focus on Nanomedicine in Cancer. International Journal of Polymeric Materials and Polymeric Biomaterials 2019, 1-42.

(8) Research, T. M. Polycaprolactone Market to be worth US\$ 300 Mn by the end of 2026 - Transparency Market Research http://www.globenewswire.com/news-release/2017/12/04/1220096/0/en/Polycaprolactone-Market-to-be-worth-US-300-Mn-by-the-end-of2026-Transparency-Market-Research.html (accessed Aug 2, 2019).

(9) Jérôme, C.; Lecomte, P. Recent Advances in the Synthesis of Aliphatic Polyesters by Ring-Opening Polymerization. Advanced Drug Delivery Reviews 2008, 60, 1056-1076.

(10) Zhang, J.; Shi, H.; Wu, D.; Xing, Z.; Zhang, A.; Yang, Y.; Li, Q. Recent Developments in Lipase-Catalyzed Synthesis of Polymeric Materials. Process Biochemistry 2014, 49, 797-806.

(11) Douka, A.; Vouyiouka, S.; Papaspyridi, L.-M.; Papaspyrides, C. A Review on Enzymatic Polymerization to Produce Polycondensation Polymers: The Case of Aliphatic Polyesters, Polyamides and Polyesteramides. Progress in Polymer Science $2017,79$.

(12) Albertsson, A.-C.; Srivastava, R. K. Recent Developments in Enzyme-Catalyzed Ring-Opening Polymerization. Advanced Drug Delivery Reviews 2008, 60, 1077-1093.

(13) Yang, Y.; Yu, Y.; Zhang, Y.; Liu, C.; Shi, W.; Li, Q. Lipase/Esterase-Catalyzed Ring-Opening Polymerization: A Green Polyester Synthesis Technique. Process Biochemistry 2011, 46, 1900-1908.

(14) Shoda, S.; Uyama, H.; Kadokawa, J.; Kimura, S.; Kobayashi, S. Enzymes as Green Catalysts for Precision Macromolecular Synthesis. Chem. Rev. 2016, 116, 2307-2413.

(15) Zhao, H. Enzymatic Ring-Opening Polymerization (ROP) of Polylactones: Roles of Non-Aqueous Solvents. Journal of Chemical Technology \& Biotechnology 2018, 93, 9-19.

(16) Kumar, A.; Gross, R. A. Candida Antartica Lipase B Catalyzed Polycaprolactone Synthesis: Effects of Organic Media and Temperature. Biomacromolecules 2000, 1, 133-138.

(17) Peeters, J. W.; van Leeuwen, O.; Palmans, A. R. A.; Meijer, E. W. Lipase-Catalyzed Ring-Opening Polymerizations of 4-Substituted عCaprolactones: Mechanistic Considerations. Macromolecules 2005, 38, 5587-5592.

(18) Poojari, Y.; Clarson, S. J. Thermal Stability of Candida Antarctica Lipase B Immobilized on Macroporous Acrylic Resin Particles in Organic Media. Biocatalysis and Agricultural Biotechnology 2013, 2, 7-11.

(19) Gross, R. A.; Ganesh, M.; Lu, W. Enzyme-Catalysis Breathes New Life into Polyester Condensation Polymerizations. Trends Biotechnol. 2010, 28, 435-443.

(20) Poojari, Y.; Beemat, J. S.; Clarson, S. J. Enzymatic Synthesis of Poly(E-Caprolactone): Thermal Properties, Recovery, and Reuse of Lipase B from Candida Antarctica Immobilized on Macroporous Acrylic Resin Particles. Polymer Bulletin 2013, 70, $1543-1552$.

(21) Polloni, A. E.; Veneral, J. G.; Rebelatto, E. A.; de Oliveira, D.; Oliveira, J. V.; Araújo, P. H. H.; Sayer, C. Enzymatic Ring Opening Polymerization of $\omega$-Pentadecalactone Using Supercritical Carbon Dioxide. The Journal of Supercritical Fluids 2017, 119, $221-228$.

(22) Zhao, H.; Nathaniel, G. A.; Merenini, P. C. Enzymatic Ring-Opening Polymerization (ROP) of Lactides and Lactone in Ionic Liquids and Organic Solvents: Digging the Controlling Factors. RSC Adv. 2017, 7, 48639-48648.

(23) Pellis, A.; Comerford, J. W.; Weinberger, S.; Guebitz, G. M.; Clark, J. H.; Farmer, T. J. Enzymatic Synthesis of Lignin Derivable Pyridine Based Polyesters for the Substitution of Petroleum Derived Plastics. Nature Communications 2019, $10,1762$.

(24) Yang, J.; Liu, Y.; Liang, X.; Yang, Y.; Li, Q. Enantio-, Regio-, and Chemoselective Lipase-Catalyzed Polymer Synthesis. Macromolecular Bioscience 2018, 18, 1800131.

(25) Champagne, E.; Strandman, S.; Zhu, X.-X. Recent Developments and Optimization of Lipase-Catalyzed Lactone Formation and RingOpening Polymerization https://onlinelibrary.wiley.com/doi/abs/10.1002/marc.201600494 (accessed Jul 31, 2019).

(26) Takwa, M.; Wittrup Larsen, M.; Hult, K.; Martinelle, M. Rational Redesign of Candida Antarctica Lipase B for the Ring Opening Polymerization of d , d -Lactide. Chemical Communications 2011, 47, 7392-7394. 
(27) Montanier, C. Y.; Chabot, N.; Emond, S.; Guieysse, D.; Remaud-Siméon, M.; Peruch, F.; André, I. Engineering of Candida Antarctica Lipase B for Poly( $\varepsilon$-Caprolactone) Synthesis. European Polymer Journal 2017, 95, 809-819.

(28) Messiha, H. L.; Ahmed, S. T.; Karuppiah, V.; Suardíaz, R.; Ascue Avalos, G. A.; Fey, N.; Yeates, S.; Toogood, H. S.; Mulholland, A. J.; Scrutton, N. S. Biocatalytic Routes to Lactone Monomers for Polymer Production. Biochemistry 2018, 57, $1997-2008$.

(29) Levisson, M.; van der Oost, J.; Kengen, S. W. M. Carboxylic Ester Hydrolases from Hyperthermophiles. Extremophiles 2009, 13, 567581 .

(30) Elleuche, S.; Schröder, C.; Sahm, K.; Antranikian, G. Extremozymes-Biocatalysts with Unique Properties from Extremophilic Microorganisms. Current Opinion in Biotechnology 2014, 29, 116-123.

(31) Sarmiento, F.; Peralta, R.; Blamey, J. M. Cold and Hot Extremozymes: Industrial Relevance and Current Trends. Front. Bioeng. Biotechnol. 2015, 3.

(32) Li, Q.; Li, G.; Yu, S.; Zhang, Z.; Ma, F.; Feng, Y. Ring-Opening Polymerization of $\varepsilon$-Caprolactone Catalyzed by a Novel Thermophilic Lipase from Fervidobacterium Nodosum. Process Biochemistry 2011, 46, 253-257.

(33) Manco, G.; Giosuè, E.; D’Auria, S.; Herman, P.; Carrea, G.; Rossi, M. Cloning, Overexpression, and Properties of a New Thermophilic and Thermostable Esterase with Sequence Similarity to Hormone-Sensitive Lipase Subfamily from the Archaeon Archaeoglobus Fulgidus. Archives of Biochemistry and Biophysics 2000, 373, 182-192.

(34) D’Auria, S.; Herman, P.; Lakowicz, J. R.; Bertoli, E.; Tanfani, F.; Rossi, M.; Manco, G. The Thermophilic Esterase from Archaeoglobus Fulgidus: Structure and Conformational Dynamics at High Temperature. Proteins: Structure, Function, and Bioinformatics 2000, 38, 351360 .

(35) Ma, J.; Li, Q.; Song, B.; Liu, D.; Zheng, B.; Zhang, Z.; Feng, Y. Ring-Opening Polymerization of $\varepsilon$-Caprolactone Catalyzed by a Novel Thermophilic Esterase from the Archaeon Archaeoglobus Fulgidus. Journal of Molecular Catalysis B: Enzymatic 2009, 56, $151-157$.

(36) Ren, H.; Xing, Z.; Yang, J.; Jiang, W.; Zhang, G.; Tang, J.; Li, Q. Construction of an Immobilized Thermophilic Esterase on Epoxy Support for Poly( $\varepsilon$-Caprolactone) Synthesis. Molecules 2016, 21.

(37) Stauch, B.; Fisher, S. J.; Cianci, M. Open and Closed States of Candida Antarctica Lipase B: Protonation and the Mechanism of Interfacial Activation. J. Lipid Res. 2015, 56, 2348-2358.

(38) De Simone, G.; Menchise, V.; Manco, G.; Mandrich, L.; Sorrentino, N.; Lang, D.; Rossi, M.; Pedone, C. The Crystal Structure of a Hyper-Thermophilic Carboxylesterase from the Archaeon Archaeoglobus Fulgidus11Edited by R. Huber. Journal of Molecular Biology 2001, 314, 507-518.

(39) Chen, V. B.; Arendall, W. B.; Headd, J. J.; Keedy, D. A.; Immormino, R. M.; Kapral, G. J.; Murray, L. W.; Richardson, J. S.; Richardson, D. C. MolProbity: All-Atom Structure Validation for Macromolecular Crystallography. Acta Crystallogr D Biol Crystallogr 2010, 66, $12-$ 21.

(40) Frisch, M.; Trucks, G.; Schlegel, H.; Scuseria, G.; Robb, M.; Cheeseman, J.; Scalmani, G.; Barone, V.; Mennucci, B.; Petersson, G.; Nakatsuji, H.; Caricato, M.; Li, X.; Hratchian, H.; Izmaylov, A.; Bloino, J.; Zheng, G.; Sonnenberg, J.; Hada, M.; Ehara, M.; Toyota, K.; Fukuda, R.; Hasegawa, J.; Ishida, M.; Nakajima, T.; Honda, Y.; Kitao, O.; Nakai, H.; Vreven, T.; Montgomery, J.; Peralta, J.; Ogliaro, F.; Bearpark, M.; Heyd, J.; Brothers, E.; Kudin, K.; Staroverov, V.; Kobayashi, R.; Normand, J.; Raghavachari, K.; Rendell, A.; Burant, J.; Iyengar, S.; Tomasi, J.; Cossi, M.; Rega, N.; Millam, J.; Klene, M.; Knox, J.; Cross, J.; Bakken, V.; Adamo, C.; Jaramillo, J.; Gomperts, R.; Stratmann, R.; Yazyev, O.; Austin, A.; Cammi, R.; Pomelli, C.; Ochterski, J.; Martin, R.; Morokuma, K.; Zakrzewski, V.; Voth, G.; Salvador, P.; Dannenberg, J.; Dapprich, S.; Daniels, A.; Farkas; Foresman, J.; Ortiz, J.; Cioslowski, J.; Fox, D. Gaussian 09, Revision B.01. Gaussian 09, Revision B.01, Gaussian, Inc., Wallingford CT 2009.

(41) Ashvar, C. S.; Devlin, F. J.; Bak, K. L.; Taylor, P. R.; Stephens, P. J. Ab Initio Calculation of Vibrational Absorption and Circular Dichroism Spectra: 6,8-Dioxabicyclo[3.2.1]Octane. J. Phys. Chem. 1996, 100, 9262-9270.

(42) Tomasi, J.; Mennucci, B.; Cammi, R. Quantum Mechanical Continuum Solvation Models. Chem. Rev. 2005, 105, $2999-3094$.

(43) Bayly, C. I.; Cieplak, P.; Cornell, W.; Kollman, P. A. A Well-Behaved Electrostatic Potential Based Method Using Charge Restraints for Deriving Atomic Charges: The RESP Model. J. Phys. Chem. 1993, 97, 10269-10280. 
(44) Salomon-Ferrer, R.; Case, D. A.; Walker, R. C. An Overview of the Amber Biomolecular Simulation Package: Amber Biomolecular Simulation Package. Wiley Interdisciplinary Reviews: Computational Molecular Science 2013, 3, 198-210.

(45) Hornak, V.; Abel, R.; Okur, A.; Strockbine, B.; Roitberg, A.; Simmerling, C. Comparison of Multiple AMBER Force Fields and Development of Improved Protein Backbone Parameters. Proteins 2006, 65, 712-725.

(46) Wang, J.; Wolf, R. M.; Caldwell, J. W.; Kollman, P. A.; Case, D. A. Development and Testing of a General Amber Force Field. J Comput Chem 2004, 25, 1157-1174.

(47) Dourado, D. F. A. R.; Swart, M.; Carvalho, A. T. P. Why the Flavin Adenine Dinucleotide (FAD) Cofactor Needs To Be Covalently Linked to Complex II of the Electron-Transport Chain for the Conversion of FADH2 into FAD. Chemistry - A European Journal 2018, 24, $5246-5252$.

(48) Warshel, A.; Levitt, M. Theoretical Studies of Enzymic Reactions: Dielectric, Electrostatic and Steric Stabilization of the Carbonium Ion in the Reaction of Lysozyme. Journal of Molecular Biology 1976, 103, 227-249.

(49) Carvalho, A. T. P.; Barrozo, A.; Doron, D.; Kilshtain, A. V.; Major, D. T.; Kamerlin, S. C. L. Challenges in Computational Studies of Enzyme Structure, Function and Dynamics. Journal of Molecular Graphics and Modelling 2014, 54, 62-79.

(50) Stewart, J. J. P. Optimization of Parameters for Semiempirical Methods V: Modification of NDDO Approximations and Application to 70 Elements. J Mol Model 2007, 13, 1173-1213.

(51) Jindal, G.; Warshel, A. Exploring the Dependence of QM/MM Calculations of Enzyme Catalysis on the Size of the QM Region. J. Phys. Chem. B 2016, 120, 9913-9921.

(52) Grimme, S.; Antony, J.; Ehrlich, S.; Krieg, H. A Consistent and Accurate Ab Initio Parametrization of Density Functional Dispersion Correction (DFT-D) for the 94 Elements H-Pu. J. Chem. Phys. 2010, 132, 154104

(53) Zhao, Y.; Truhlar, D. G. The M06 Suite of Density Functionals for Main Group Thermochemistry, Thermochemical Kinetics, Noncovalent Interactions, Excited States, and Transition Elements: Two New Functionals and Systematic Testing of Four M06-Class Functionals and 12 Other Functionals. Theor Chem Account 2008, 120, 215-241.

(54) Chai, J.-D.; Head-Gordon, M. Long-Range Corrected Hybrid Density Functionals with Damped Atom-Atom Dispersion Corrections. Phys Chem Chem Phys 2008, 10, 6615-6620.

(55) Carvalho, A. T. P.; Dourado, D. F. A. R.; Skvortsov, T.; de Abreu, M.; Ferguson, L. J.; Quinn, D. J.; Moody, T. S.; Huang, M. Catalytic Mechanism of Phenylacetone Monooxygenases for Non-Native Linear Substrates. Phys Chem Chem Phys 2017, 19, 26851-26861.

(56) Bowman, A. L.; Grant, I. M.; Mulholland, A. J. QM/MM Simulations Predict a Covalent Intermediate in the Hen Egg White Lysozyme Reaction with Its Natural Substrate. Chem. Commun. (Camb.) 2008, No. 37, 4425-4427.

(57) Bakowies, D.; Thiel, W. Hybrid Models for Combined Quantum Mechanical and Molecular Mechanical Approaches. J. Phys. Chem. 1996, 100, 10580-10594.

(58) Nam, K.; Gao, J.; York, D. M. An Efficient Linear-Scaling Ewald Method for Long-Range Electrostatic Interactions in Combined QM/MM Calculations. J. Chem. Theory Comput. 2005, 1, 2-13.

(59) Grossfield, A. "WHAM: The Weighted Histogram Analysis Method", version Revision 7140, June 2005, http://membrane.urmc.rochester.edu/wordpress/?page_id=26.

(60) Uppenberg, J.; Hansen, M. T.; Patkar, S.; Jones, T. A. The Sequence, Crystal Structure Determination and Refinement of Two Crystal Forms of Lipase B from Candida Antarctica. Structure 1994, 2, 293-308.

(61) Publishers, B. S. Protein \& Peptide Letters, 6th ed.; Bentham Science Publishers; Vol. 4.

(62) Skjøt, M.; De Maria, L.; Chatterjee, R.; Svendsen, A.; Patkar, S. A.; Østergaard, P. R.; Brask, J. Understanding the Plasticity of the $\alpha / \beta$ Hydrolase Fold: Lid Swapping on the Candida Antarctica Lipase B Results in Chimeras with Interesting Biocatalytic Properties. ChemBioChem 2009, 10, 520-527.

(63) Tian, W.; Chen, C.; Lei, X.; Zhao, J.; Liang, J. CASTp 3.0: Computed Atlas of Surface Topography of Proteins. Nucleic Acids Res 2018, 46, W363-W367. 
(64) Figueiredo, P.; Almeida, B. C.; Carvalho, A. T. P. Enzymatic Polymerization of PCL-PEG Co-Polymers for Biomedical Applications. Front. Mol. Biosci. 2019, 6.

(65) Almeida, B. C.; Figueiredo, P.; Carvalho, A. T. P. Polycaprolactone Enzymatic Hydrolysis: A Mechanistic Study. ACS Omega 2019, 4, $6769-6774$.

(66) Brady, L.; Brzozowski, A. M.; Derewenda, Z. S.; Dodson, E.; Dodson, G.; Tolley, S.; Turkenburg, J. P.; Christiansen, L.; Huge-Jensen, B.; Norskov, L.; Thim, L.; Menge, U. A Serine Protease Triad Forms the Catalytic Centre of a Triacylglycerol Lipase. Nature 1990, 343 , 767.

(67) Bezborodov, A. M.; Zagustina, N. A. Lipases in Catalytic Reactions of Organic Chemistry. Appl Biochem Microbiol 2014, 50, 313337.

(68) Simón, L.; Goodman, J. M. Enzyme Catalysis by Hydrogen Bonds: The Balance between Transition State Binding and Substrate Binding in Oxyanion Holes. J. Org. Chem. 2010, 75, 1831-1840.

(69) Raza, S.; Fransson, L.; Hult, K. Enantioselectivity in Candida Antarctica Lipase B: A Molecular Dynamics Study. Protein Sci. 2001, $10,329-338$

(70) Almeida, B. C.; Figueiredo, P.; Carvalho, A. T. P. Polycaprolactone Enzymatic Hydrolysis: A Mechanistic Study. ACS Omega 2019, 4, $6769-6774$.

(71) van der Mee, L.; Helmich, F.; de Bruijn, R.; Vekemans, J. A. J. M.; Palmans, A. R. A.; Meijer, E. W. Investigation of Lipase-Catalyzed Ring-Opening Polymerizations of Lactones with Various Ring Sizes: Kinetic Evaluation. Macromolecules 2006, 39, 5021-5027.

(72) Escorcia, A. M.; Sen, K.; Daza, M. C.; Doerr, M.; Thiel, W. Quantum Mechanics/Molecular Mechanics Insights into the Enantioselectivity of the O-Acetylation of (R,S)-Propranolol Catalyzed by Candida Antarctica Lipase B. ACS Catal. $2017,7,115-127$.

(73) Świderek, K.; Martí, S.; Moliner, V. Theoretical Study of Primary Reaction of Pseudozyma Antarctica Lipase B as the Starting Point To Understand Its Promiscuity. ACS Catal. 2014, 4, 426-434.

(74) Cen, Y.; Singh, W.; Arkin, M.; Moody, T. S.; Huang, M.; Zhou, J.; Wu, Q.; Reetz, M. T. Artificial Cysteine-Lipases with High Activity and Altered Catalytic Mechanism Created by Laboratory Evolution. Nat Commun 2019, 10, 1-10.

(75) Kobayashi, S. Enzymatic Ring-Opening Polymerization of Lactones by Lipase Catalyst: Mechanistic Aspects. Macromolecular Symposia 2006, 240, 178-185.

(76) Poojari, Y.; Beemat, J. S.; Clarson, S. J. Enzymatic Synthesis of Poly(E-Caprolactone): Thermal Properties, Recovery, and Reuse of Lipase B from Candida Antarctica Immobilized on Macroporous Acrylic Resin Particles. Polymer Bulletin 2013, 70, 1543-1552.

(77) Evans, M. G.; Polanyi, M. Some Applications of the Transition State Method to the Calculation of Reaction Velocities, Especially in Solution. Trans. Faraday Soc. 1935, 31, 875-894. 


\section{SUPPORTING INFORMATION}

\section{Index}

Material and Methods

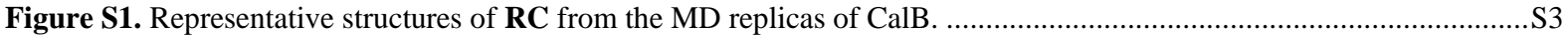

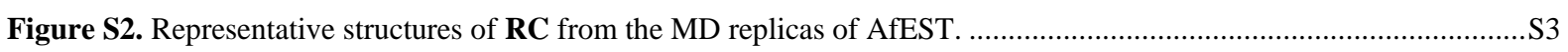

Figure S3. Energetic profile for proton transfer (PT) in the stepwise mechanism. ........................................................... 3

Figure S4. Calculated PMF for the acylation step (formation of the EAM structure) in CalB .........................................S4

Figure S5. Calculated PMF for the acylation step (formation of the EAM structure) in AfEST. ......................................S4

Figure S6. Calculated PMF for the ring-opening reaction (EAM formation) in CalB when the histidine residue is in a similar

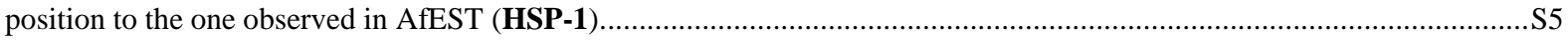

Figure S7. Representative structures of EAM with 6-HCA from the MD replicas of CalB ..............................................S5

Figure S8. Representative structures of EAM with 6-HCA from the MD replicas of AfEST............................................5

Figure S9. Calculated PMF for the deacylation step (formation of the PC structure) in CalB. .......................................... 6

Figure S10. Calculated PMF for the deacylation step (formation of the PC structure) in AfEST. ....................................S6

Figure S11. Superimposition of the INT-1 structure optimize with PM6 (orange) and B3LYP (green). ............................S6

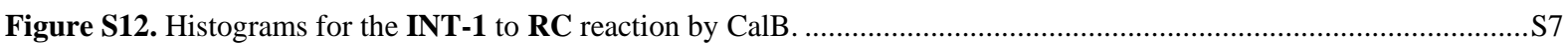

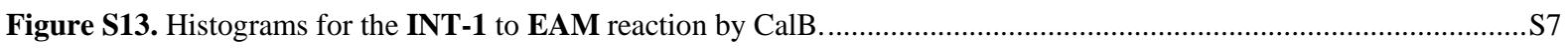

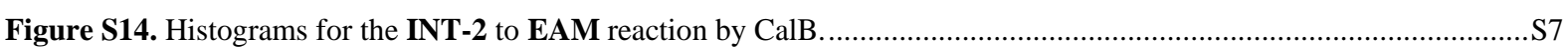

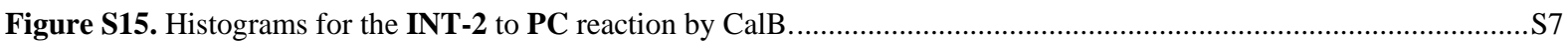

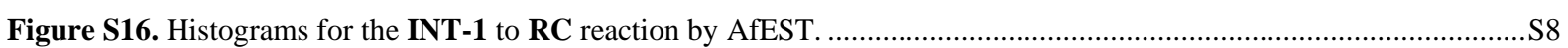

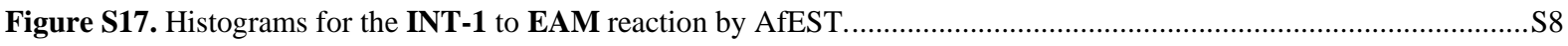

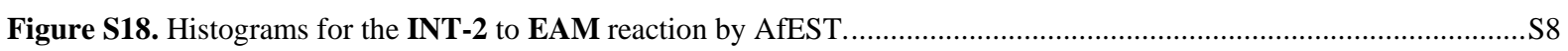

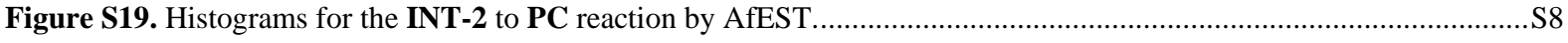

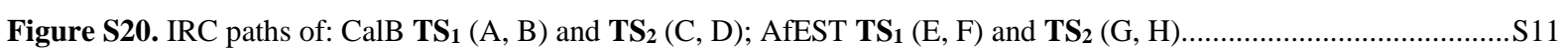

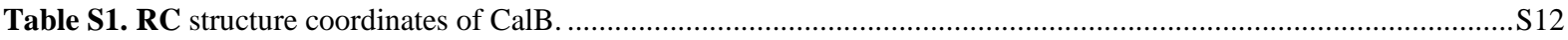

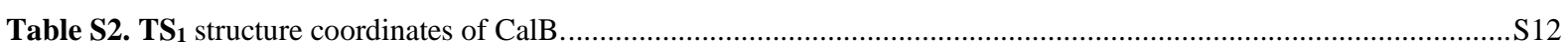

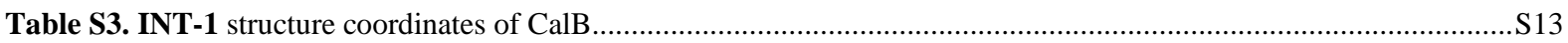

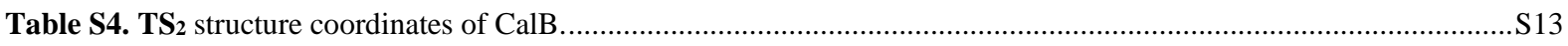

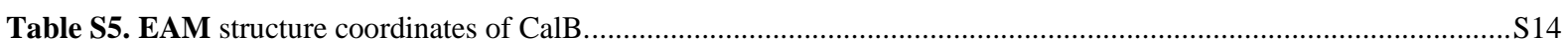

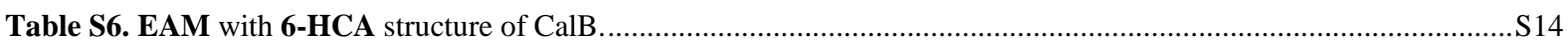

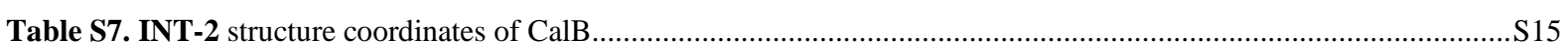

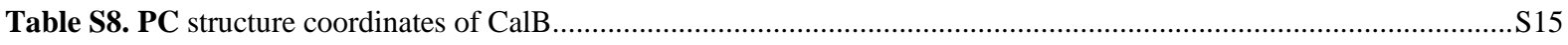

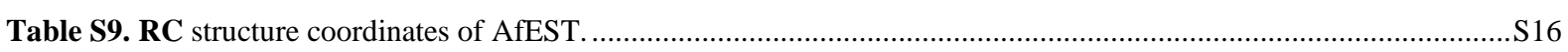

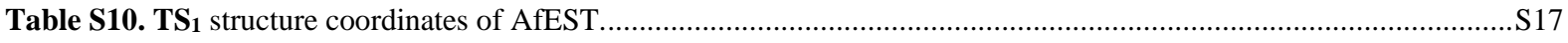

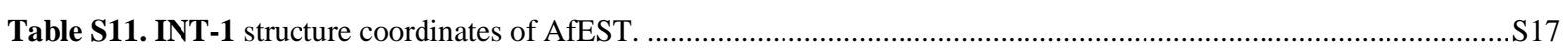

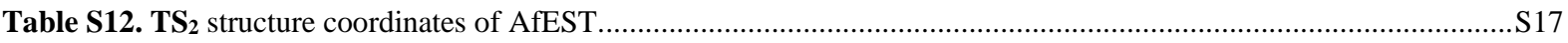

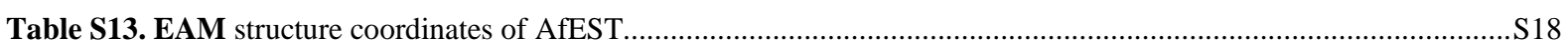

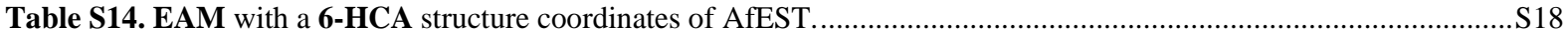

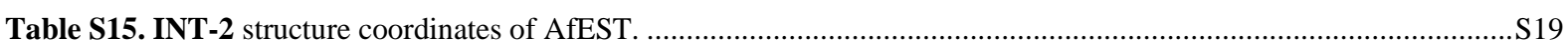

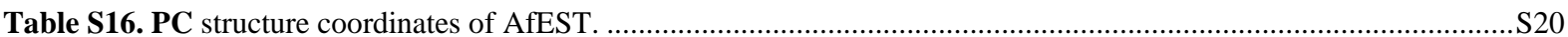

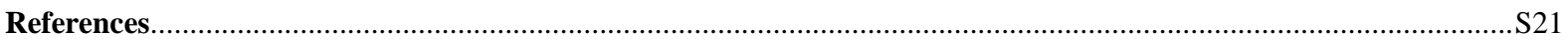




\section{Material and Methods}

\section{Molecular Docking}

Molecular docking was performed with AutoDock4.2 suite of programs with the Lamarckian Genetic Algorithm (LGA). ${ }^{1}$ A grid box was centred on the oxygen of the catalytic serine side-chain of the (residue 105 for CalB and 160 for AfEST). A total of 100 LGA runs were carried out for each ligand-protein complex. The population was 300, the maximum number of generations was 27,000 and the maximum number of energy evaluations was $2,500,000$. These initial structures were used to model the INT-1 and INT-2 intermediates.

\section{Molecular Dynamics}

The structures were placed within a pre-equilibrated octahedral box of toluene with a distance between the surface of the protein to the box of $10.0 \AA$. Counter ions were added to make the entire system neutral. The systems were subjected to two initial energy minimizations and to 500 ps of equilibration in an $N V T$ ensemble using Langevin dynamics with small restraints on the protein of $10.0 \mathrm{kcal} / \mathrm{mol}$ to heat the systems. Production simulations of $50 \mathrm{~ns}$ were carried out at $300 \mathrm{~K}$ for CalB and $353.15 \mathrm{~K}$ for AfEST in the NPT ensemble using Langevin dynamics with a collision frequency of $1 \mathrm{ps}^{-1}$. Constant pressure periodic boundary conditions were imposed with an average pressure of $1 \mathrm{~atm}$. Isotropic position scaling was used to maintain pressure with a relaxation time of $2 \mathrm{ps}$. The time step was set to $2 \mathrm{fs}$. SHAKE constraints were applied to all bonds involving hydrogen atoms. ${ }^{2}$ The Particle Mesh Ewald (PME) method $^{3}$ was used to calculate electrostatic interactions with a cut-off distance of $10.0 \AA$.

\section{Reaction Coordinates}

Two reaction coordinates (Scheme 1) were used in the presented simulations: i) the distance between the tetrahedral carbon and the corresponding oxygen atom ( $\omega$ and $\sigma)$; ii) the distance between the histidine proton HE and the corresponding oxygen atom $(\theta$ and $\phi)$. The i) reaction coordinate was used in simulations INT-1 to RC (CalB: $1.4-3.0 \AA$ and AfEST: 1.4-2.8 $\AA$ ), INT-1 to EAM (CalB: 1.4-3.0 $\AA$ ) and INT-2 to PC (CalB and AfEST: 1.4-2.5 $⿱$ ). For the remaining simulations, INT-1 to EAM (CalB: 2.2-1.0 $\AA$ and AfEST: 3.4-1.0 $\AA$ ) and INT-2 to EAM (AfEST: 2.5-1.0 $\AA$ ), the ii) reaction coordinate was applied. Histograms S12-S15 (CalB) and S16-S19 (AfEST) show that we have adequate sampling in all cases.

\section{PMF corrections}

The high-level layer corrections were applied to the calculated PM6 PMFs, following a previously reported protocol. ${ }^{4}$ The corrected PMFs free energy can be defined by equation (1) if, at both levels of theory, the interaction energy of the QM/MM does not change significantly:

$$
\Delta G_{P M F, \text { corr }}(\text { protein })=\Delta G_{P M F, P M 6}(\text { protein })+\left[\Delta G_{B 3 L Y P}(\text { model })-\Delta G_{P M 6}(\text { model })\right]
$$

The term $\left[\Delta G_{B 3 L Y P}(\right.$ model $)-\Delta G_{P M 6}($ model $\left.)\right]$, is the difference between the free energies for the high-level layer model calculated by B3LYP/6-31G(d) with Grimme D3 dispersion ${ }^{5}$ and PM6, respectively.

The free energy for the corrected PMF can be described by equation (2) if the thermal and zero-point energy corrections are considered negligible due to their small quantity:

$$
\Delta G_{P M F, \text { corr }}(\text { protein })=\Delta G_{P M F, P M 6}(\text { protein })+\left[E_{B 3 L Y P}(\text { model })-E_{P M 6}(\text { model })\right]
$$

The term $\left[E_{B 3 L Y P}(\right.$ model $)-E_{P M 6}($ model $\left.)\right]$, corresponds to the energetic differences between the stationary points that were optimized through B3LYP/6-31G(d) with the Grimme D3 dispersion correction ${ }^{5}$ and PM6, respectively.

The corrections were first performed to the reagents and products of each reaction, and the corrections for the remaining potential surface were interpolated by the addition of an increment factor to each point.

\section{Transition States}

The structures of the TSs were obtained from the PM6 PMFs and reoptimized using B3LYP/6-31G(d) with the Grimme D3 dispersion correction ${ }^{5}$ and PM6 in the gas phase. All the atoms of the truncated bonds to the protein were kept fixed. The nature of the trasition states was verified by performing frequency calculations and following the intrinsic reaction coordinates (IRCs).

\section{Histidine Simulation}

To obtain the structure with the H224 $\mathrm{CalB}$ in a similar position of $\mathrm{H} 285_{\mathrm{AfEST}}$ (HSP-1), we performed a QM/MM simulation with the inverted reaction coordinate in CalB (increasing the distance between the $\mathrm{O}_{\text {lac }}$ and HE) until the distance between them were similar to the one observed in AfEST (around 3.4 $\AA$ ). Then, we ran the forward coordinate reaction (reducing the distance between the $\mathrm{O}_{\text {lac }}$ and $\mathrm{HE}$ ), also with a QM/MM scan and with the setup already described, using a representative snapshot with the $\mathrm{HE}_{\mathrm{H} 224} 3.4 \AA$ away from Olac. The PMFwas computed using WHAM. 


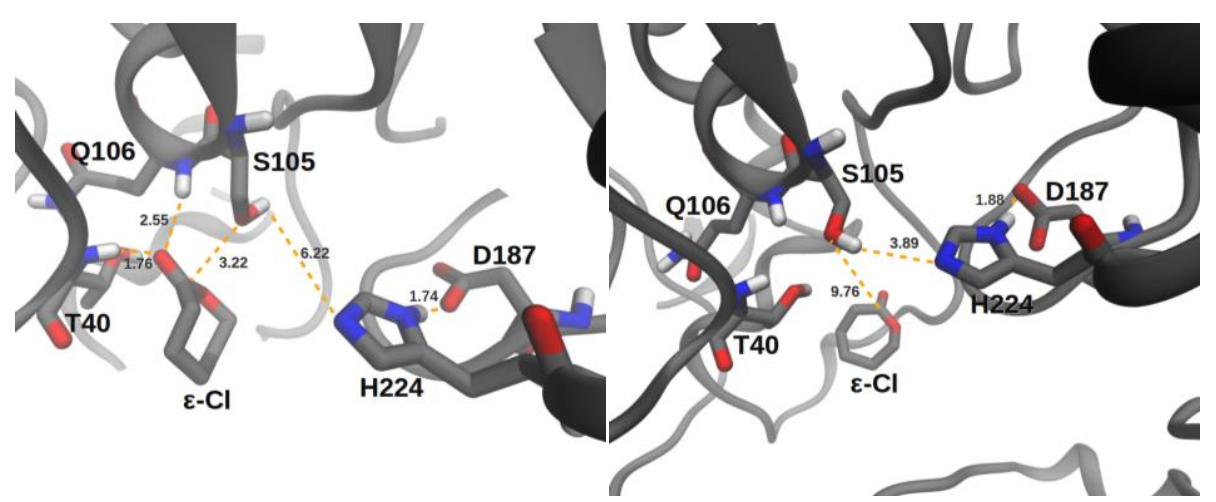

Figure S1. Representative structures of RC from the MD replicas of CalB.

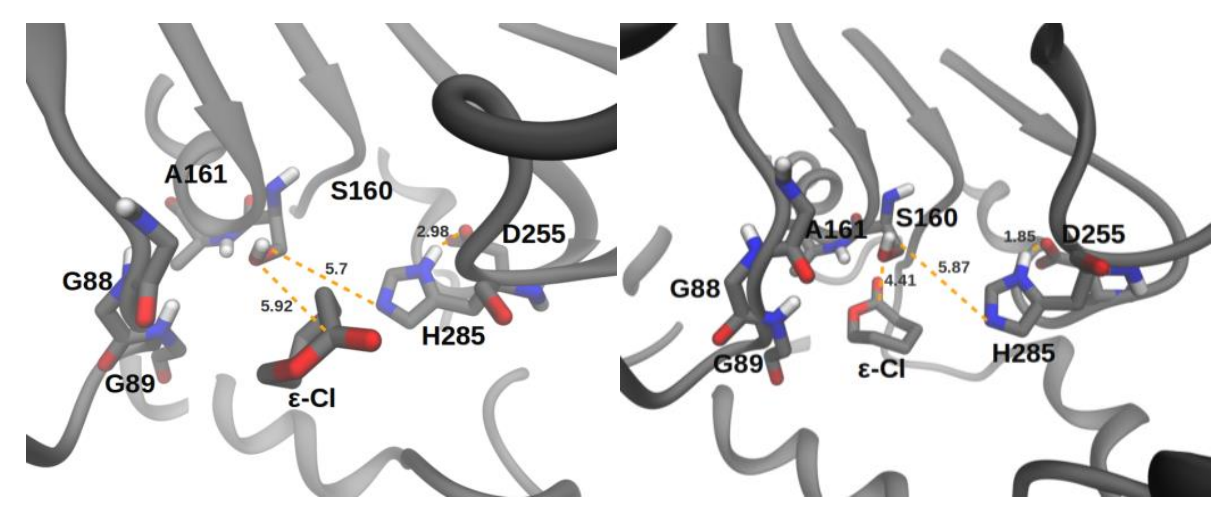

Figure S2. Representative structures of $\mathbf{R C}$ from the MD replicas of AfEST.

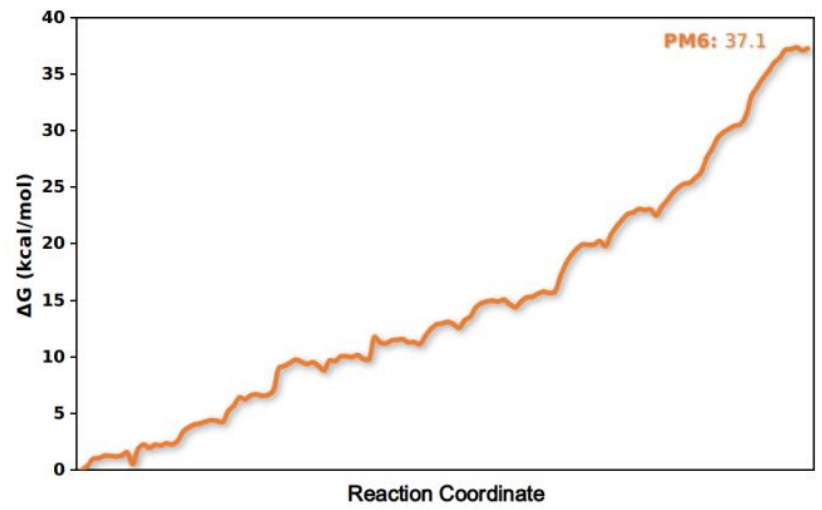

Figure S3. Energetic profile for proton transfer (PT) in the stepwise mechanism. The much higher free energy barrier for the PT of the stepwise mechanism shows that the concerted mechanism is more feasible. 

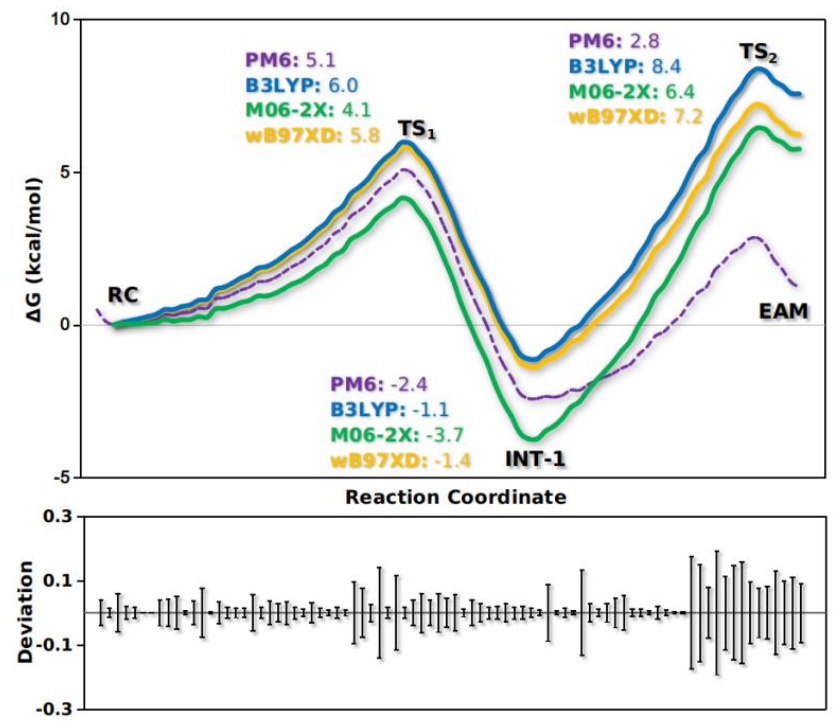

Figure S4. Calculated PMF for the acylation step (formation of the EAM structure) in CalB. The dashed line represents the PM6 PMF, the remaining denotes the corrected free energies calculated with different theory levels and the statistical uncertainty panel related to the PMF.
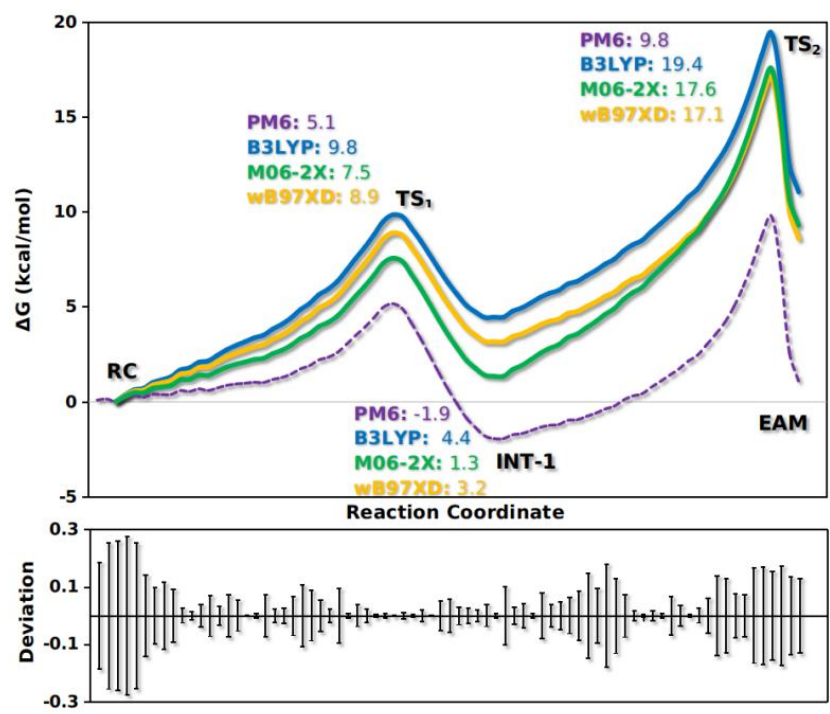

Figure S5. Calculated PMF for the acylation step (formation of the EAM structure) in AfEST. The dashed line represents the PM6 PMF, the remaining denotes the corrected free energies calculated with different theory levels and the statistical uncertainty panel related to the PMF. 


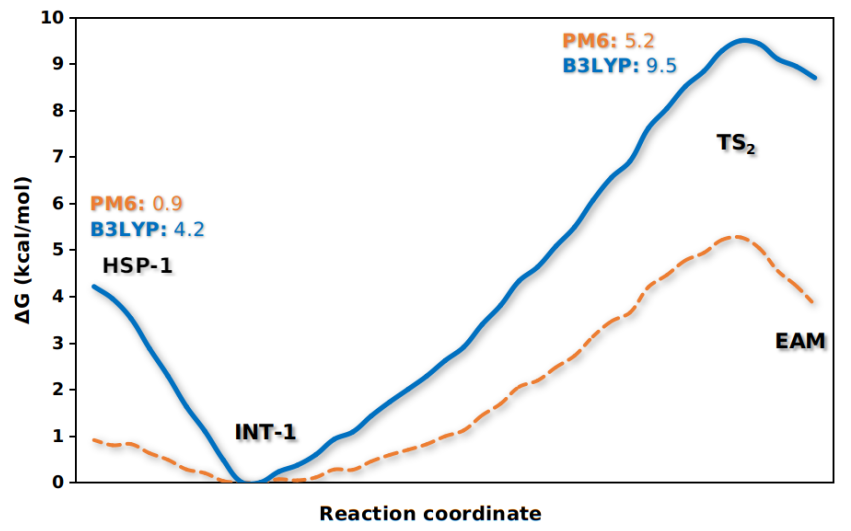

Figure S6. Calculated PMF for the ring-opening reaction (EAM formation) in CalB when the histidine residue is in a similar position to the one observed in AfEST (HSP-1). The PMF starts with the histidine in the HSP-1 position (3.4 $\AA$ ), evolving to the INT-1 (2.2- $2.1 \AA$, most stable structure) with the release of $4.2 \mathrm{kcal} / \mathrm{mol}$. Finally, the reaction proceeds to the EAM structure through $\mathbf{T S}_{\mathbf{2}}$ with $9.5 \mathrm{kcal} / \mathrm{mol}$. The orange dashed line represents the PM6 PMF and the blue solid line, the corrected PM6 profile with the B3LYP theory level with empirical dispersion.

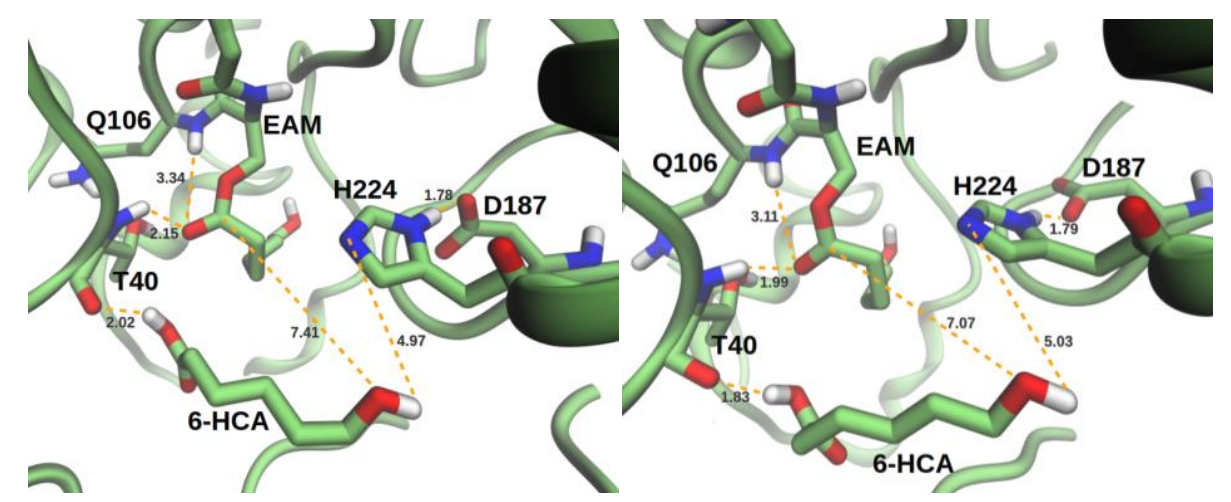

Figure S7. Representative structures of EAM with 6-HCA from the MD replicas of CalB.

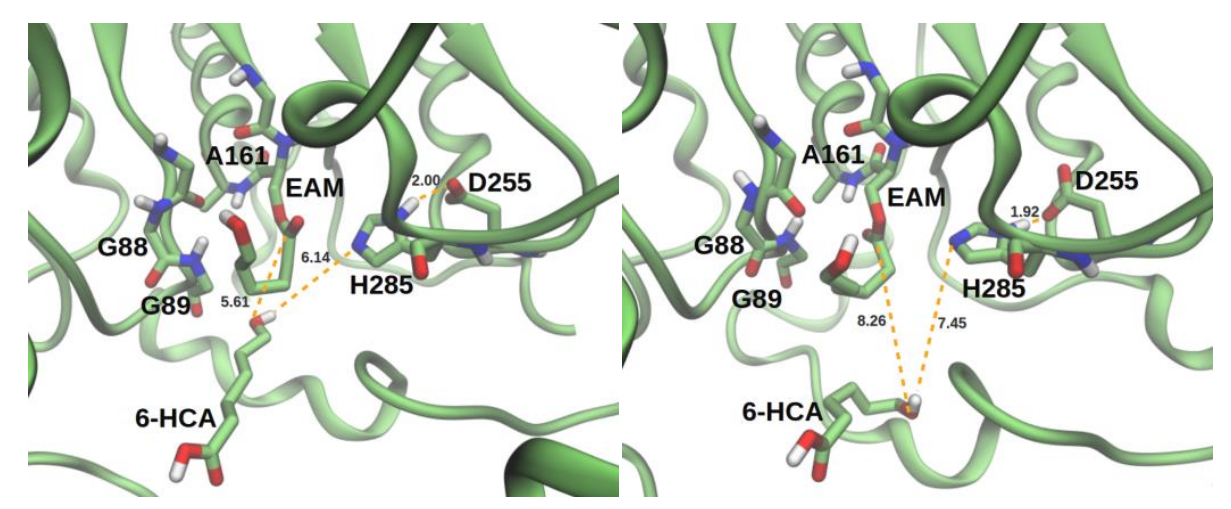

Figure S8. Representative structures of EAM with 6-HCA from the MD replicas of AfEST. 


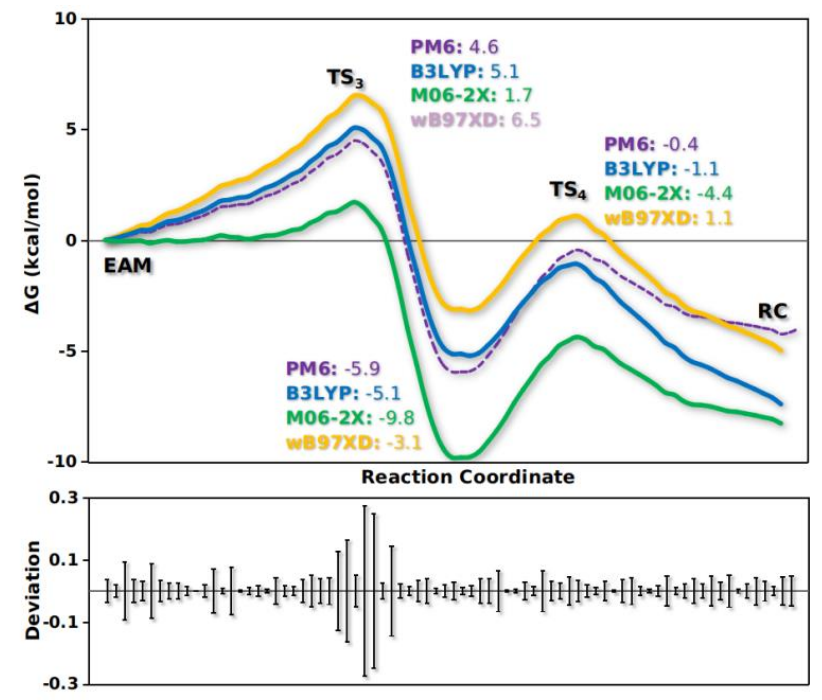

Figure S9. Calculated PMF for the deacylation step (formation of the PC structure) in CalB. The dashed line represents the PM6 PMF, the remaining denotes the corrected free energies calculated with different theory levels and the statistical uncertainty panel related to the PMF energies.

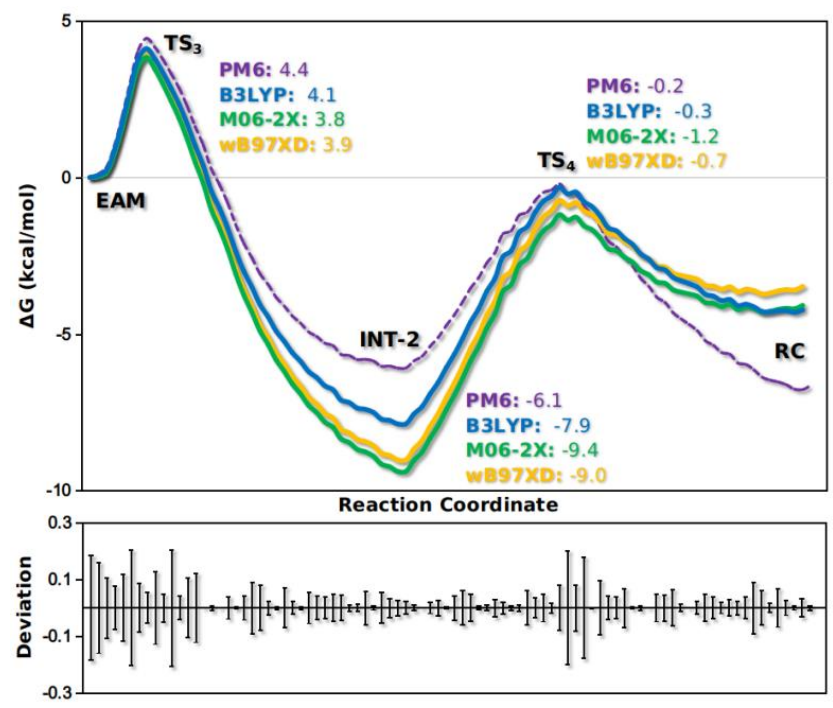

Figure S10. Calculated PMF for the deacylation step (formation of the PC structure) in AfEST. The dashed line represents the PM6 PMF, the remaining denotes the corrected free energies calculated with different theory levels and the statistical uncertainty panel related to the PMF.

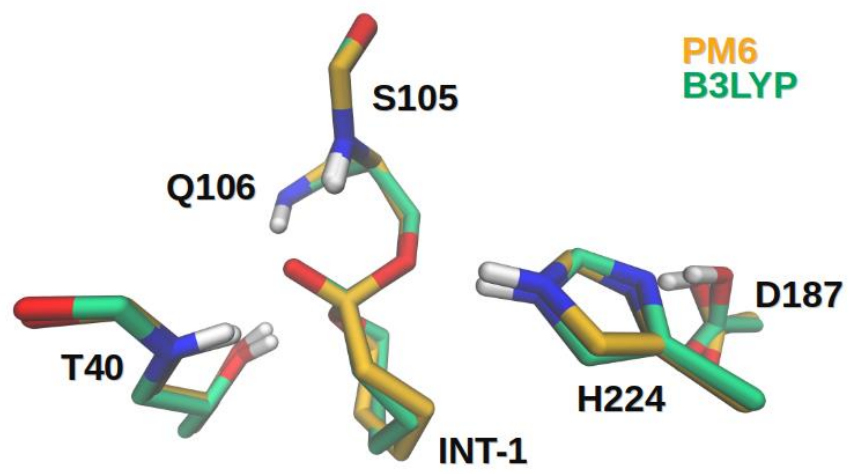

Figure S11. Superimposition of the INT-1 structure optimize with PM6 (orange) and B3LYP (green). 

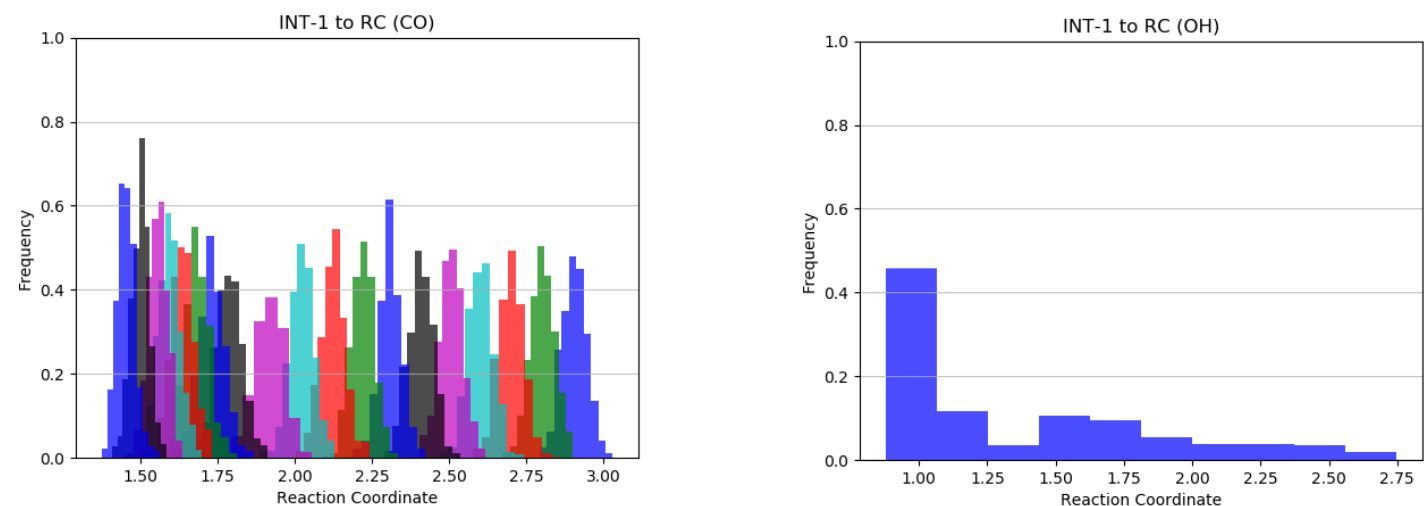

Figure S12. Histograms for the INT-1 to RC reaction by CalB. On the left is the data represented for the i) reaction coordinate and on the right for ii).
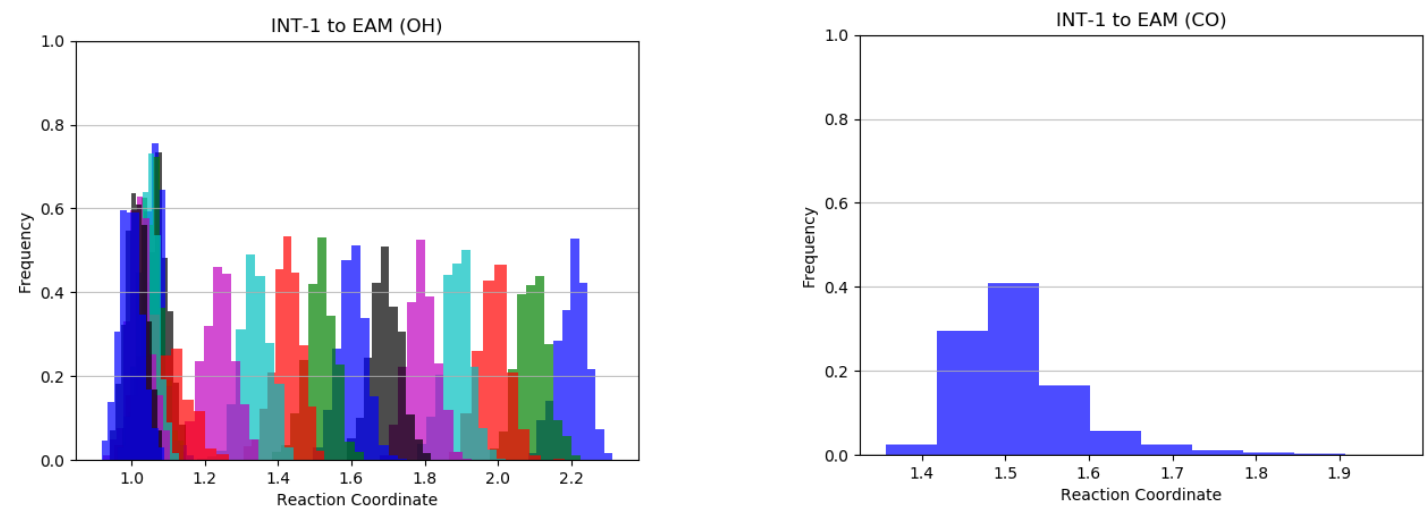

Figure S13. Histograms for the INT-1 to EAM reaction by CalB. On the right is the data represented for the i) reaction coordinate and on the left for ii).
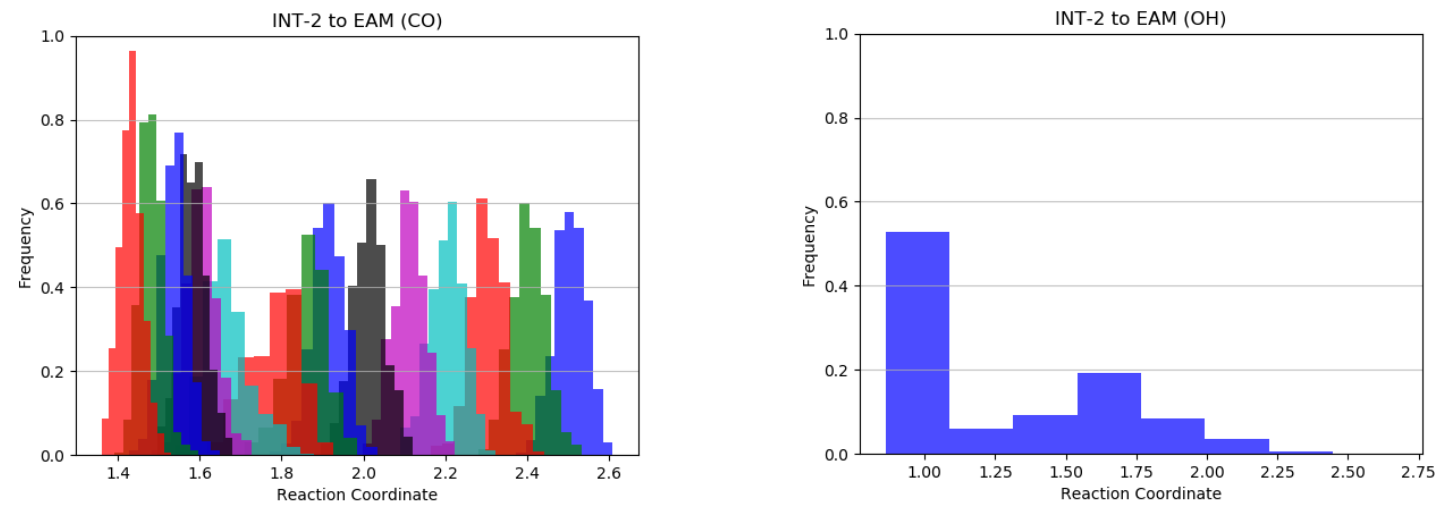

Figure S14. Histograms for the INT-2 to EAM reaction by CalB. On the left is the data represented for the i) reaction coordinate and on the right for ii).
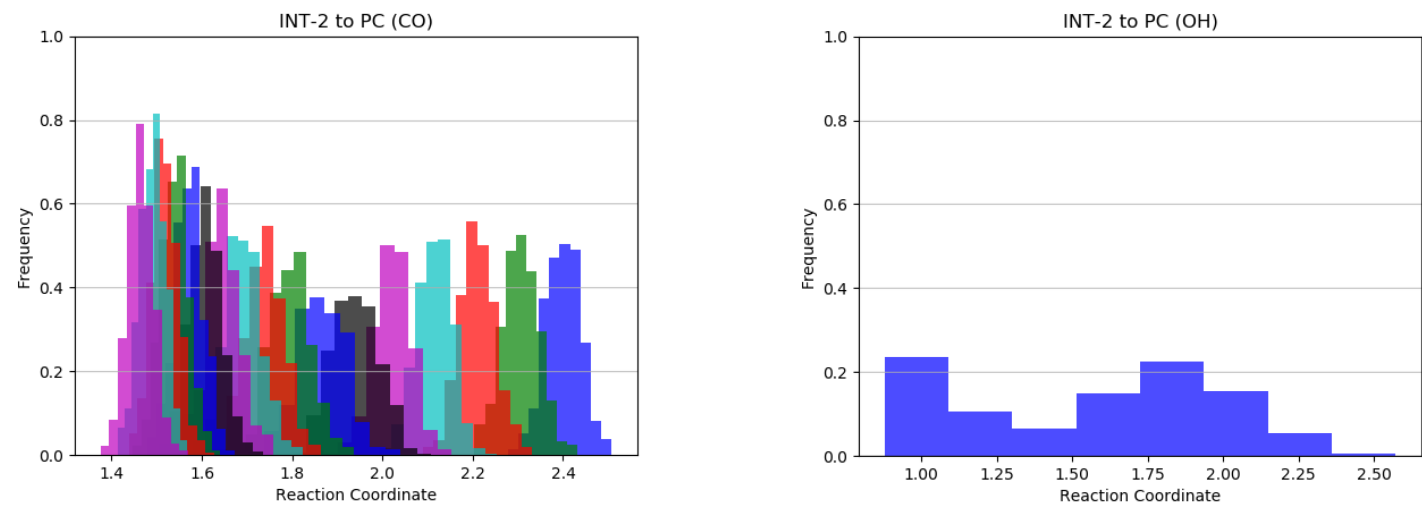

Figure S15. Histograms for the INT-2 to PC reaction by CalB. On the left is the data represented for the i) reaction coordinate and on the right for ii). 

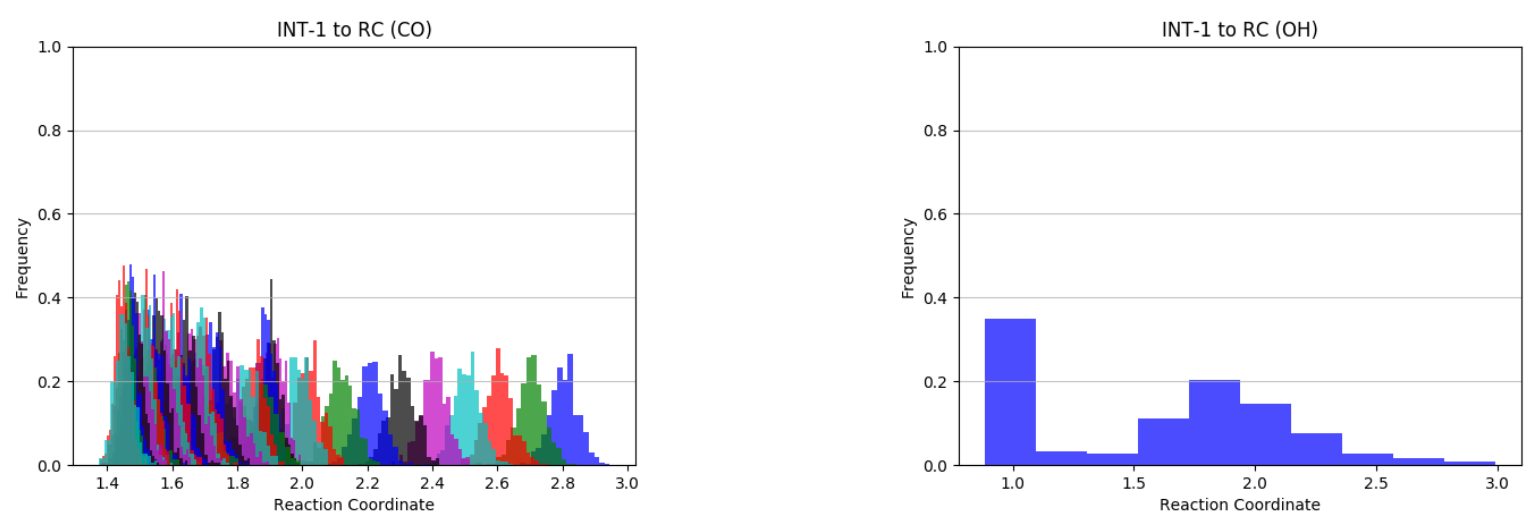

Figure S16. Histograms for the INT-1 to RC reaction by AfEST. On the left is the data represented for the i) reaction coordinate and on the right for ii).
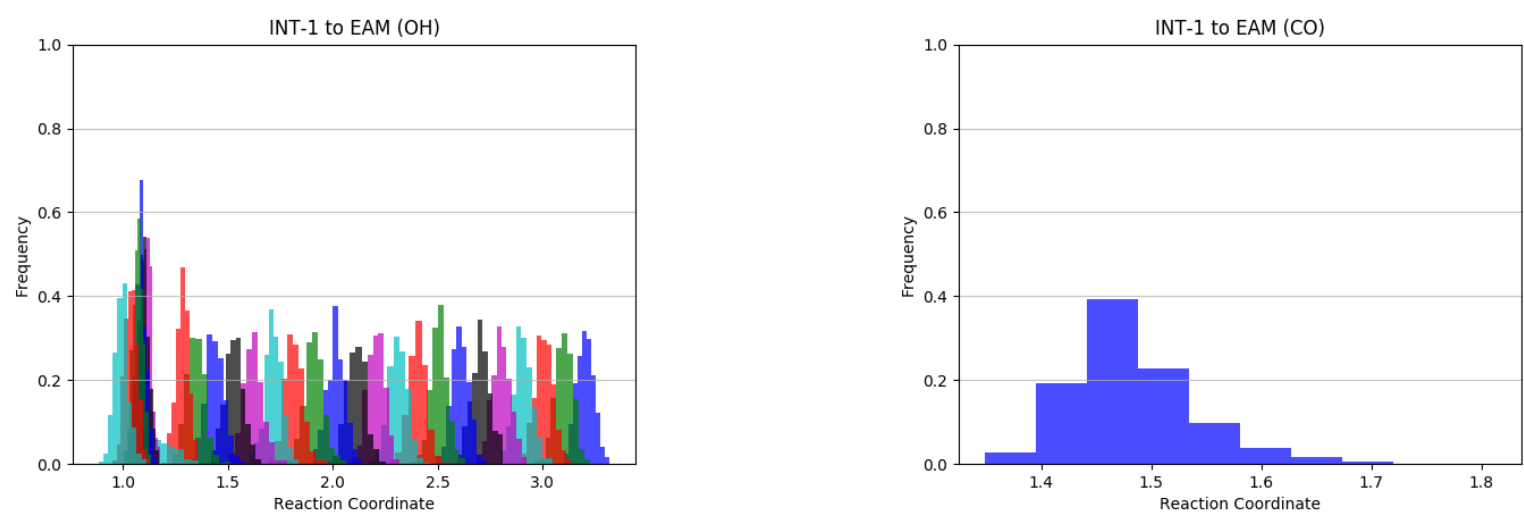

Figure S17. Histograms for the INT-1 to EAM reaction by AfEST. On the right is the data represented for the i) reaction coordinate and on the left for ii)
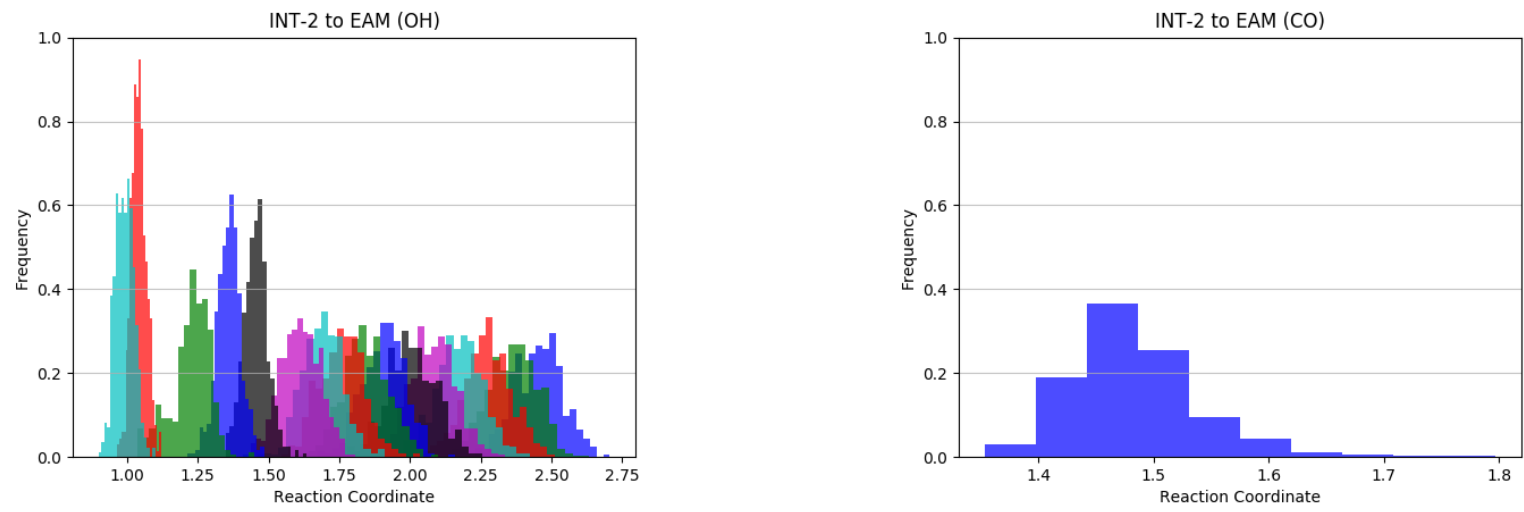

Figure S18. Histograms for the INT-2 to EAM reaction by AfEST. On the right is the data represented for the i) reaction coordinate and on the left for ii).
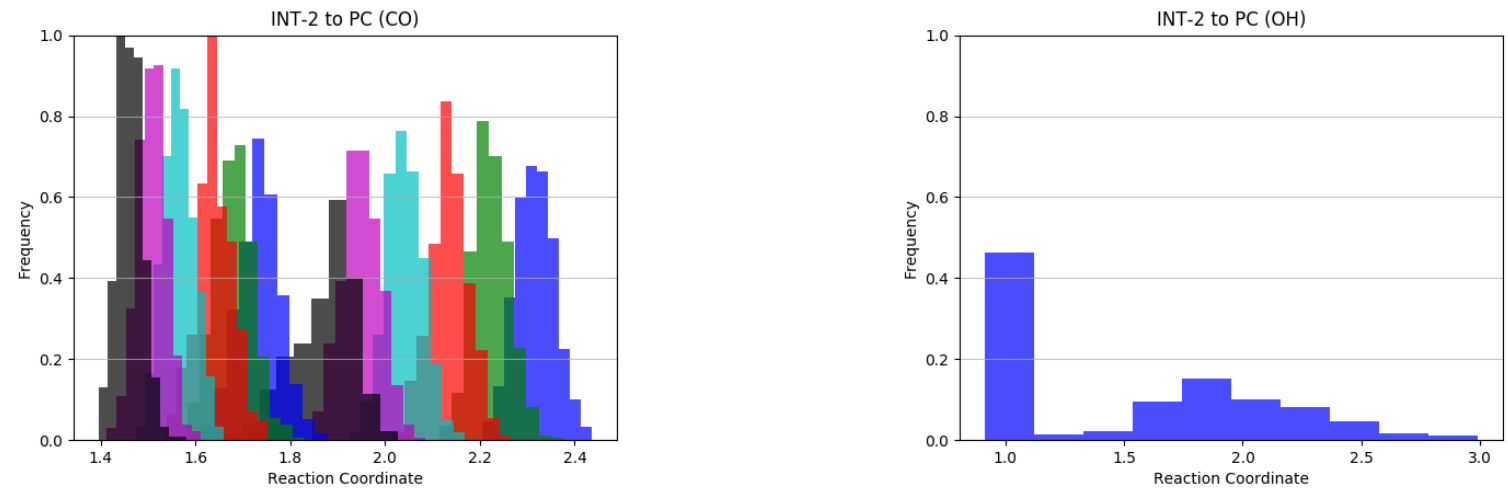

Figure S19. Histograms for the INT-2 to PC reaction by AfEST. On the left is the data represented for the i) reaction coordinate and on the right for ii). 

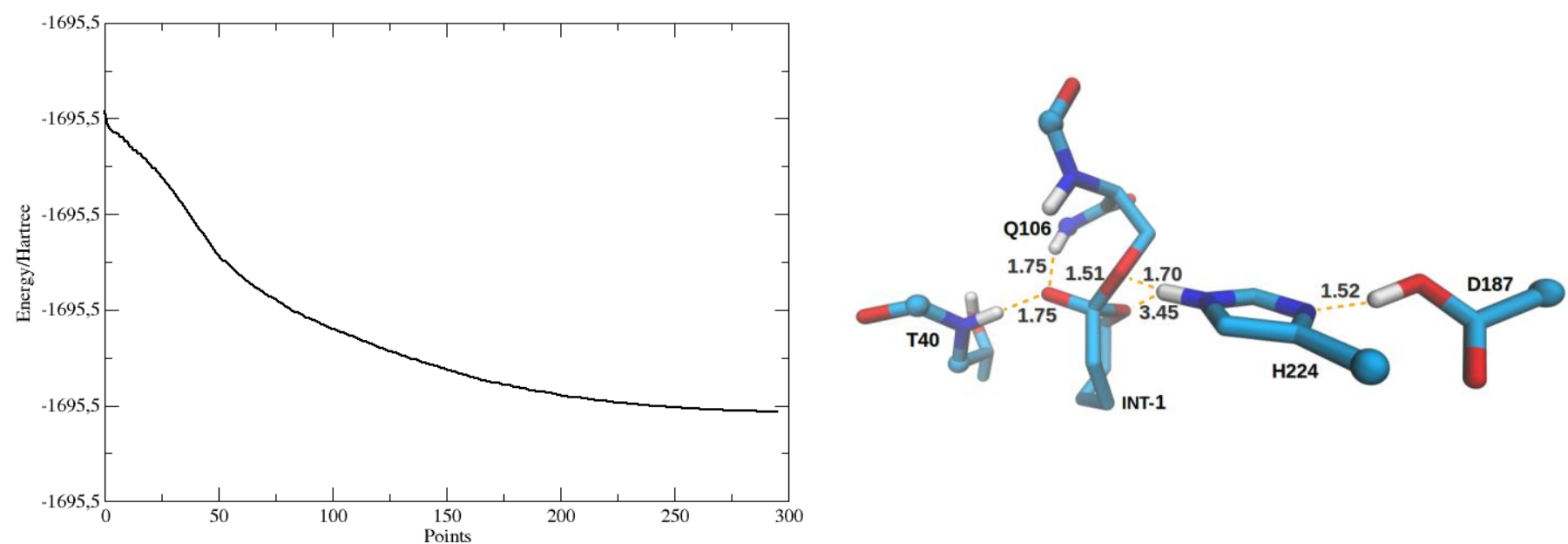

B
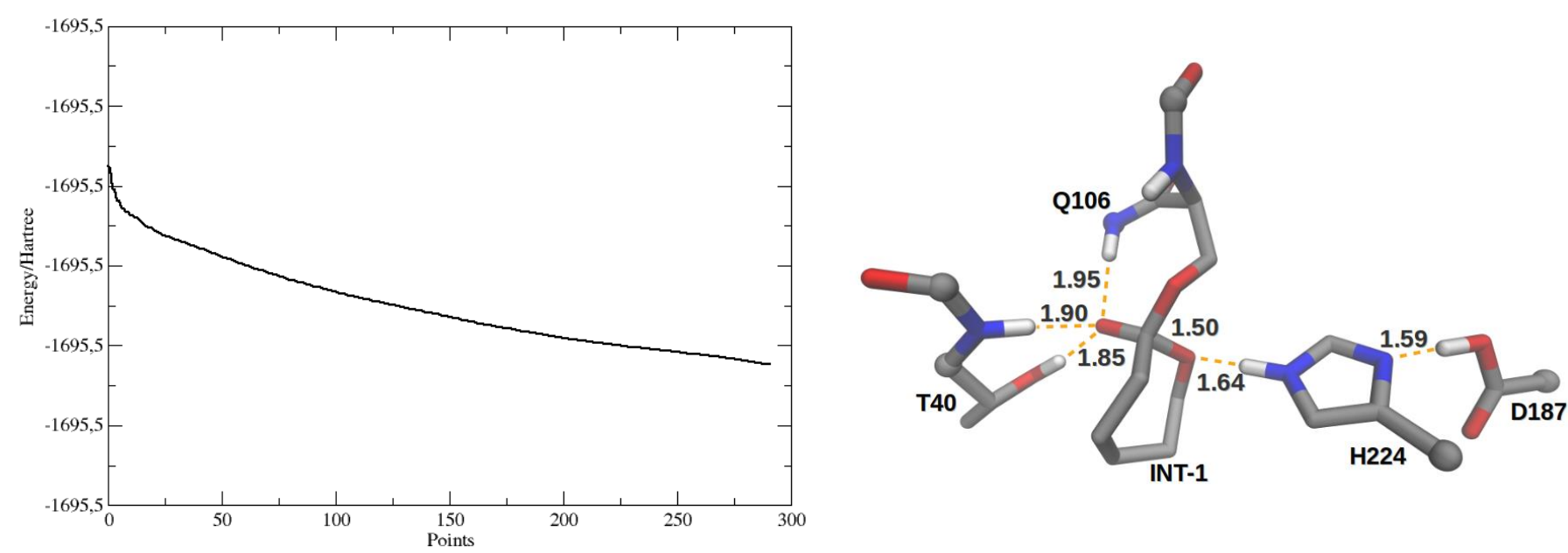

C
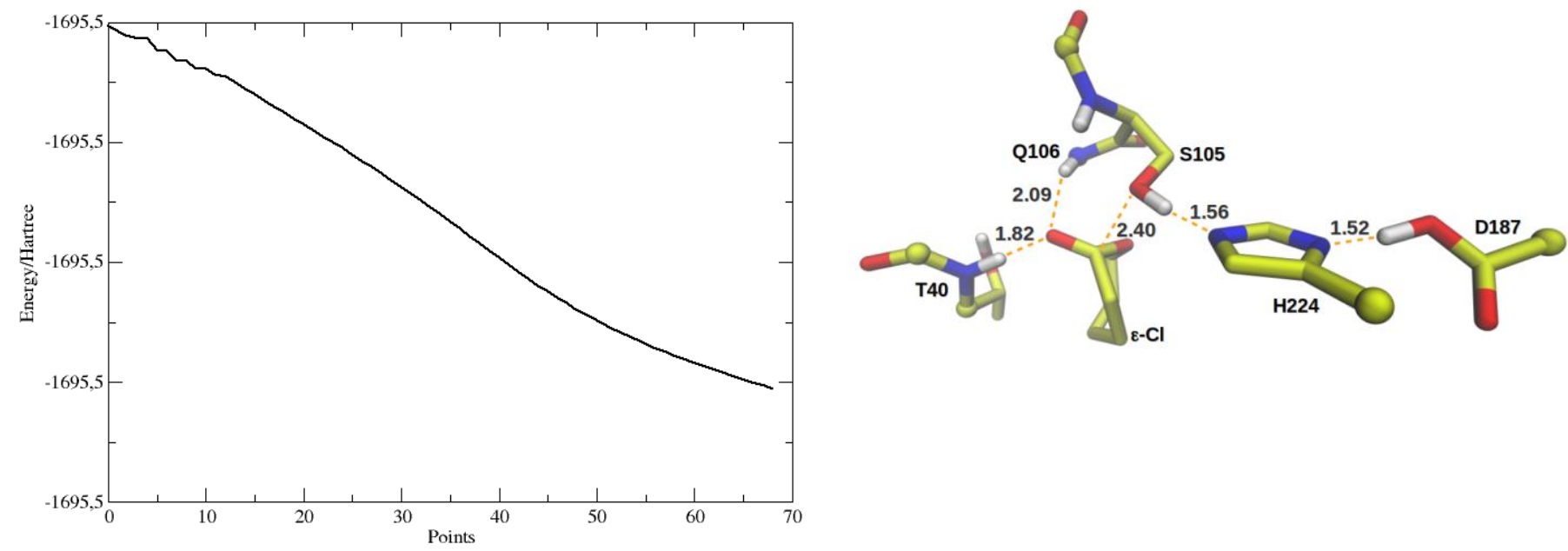
D
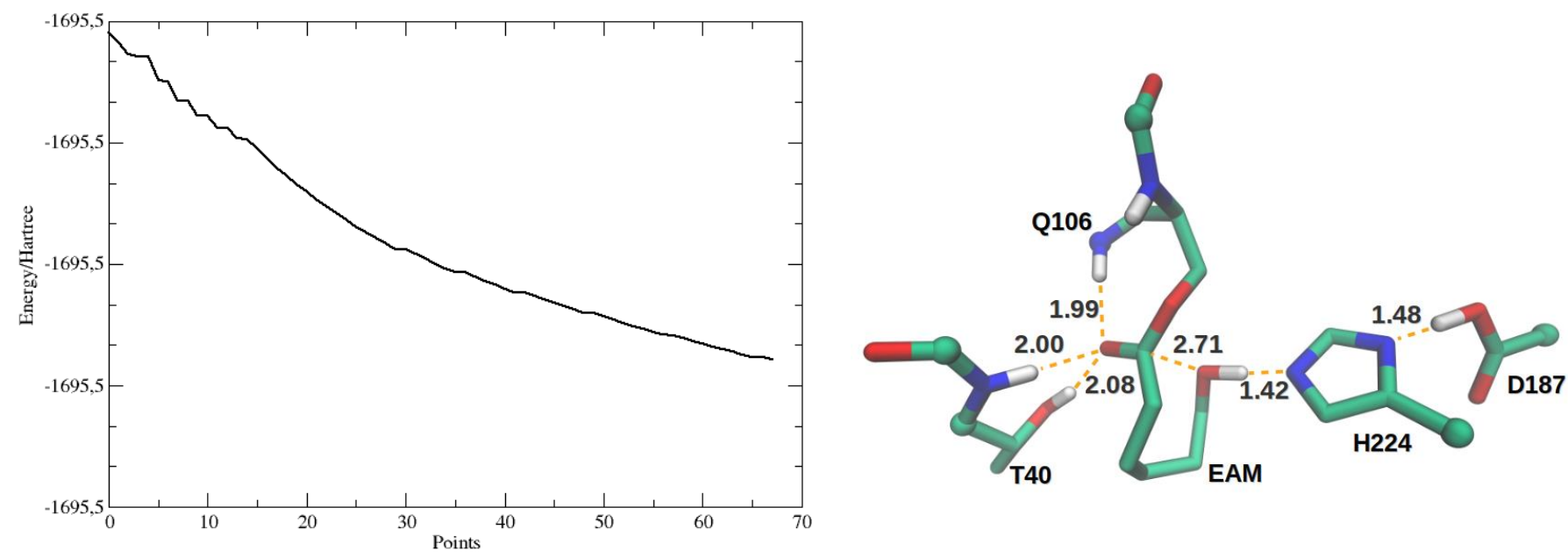

E
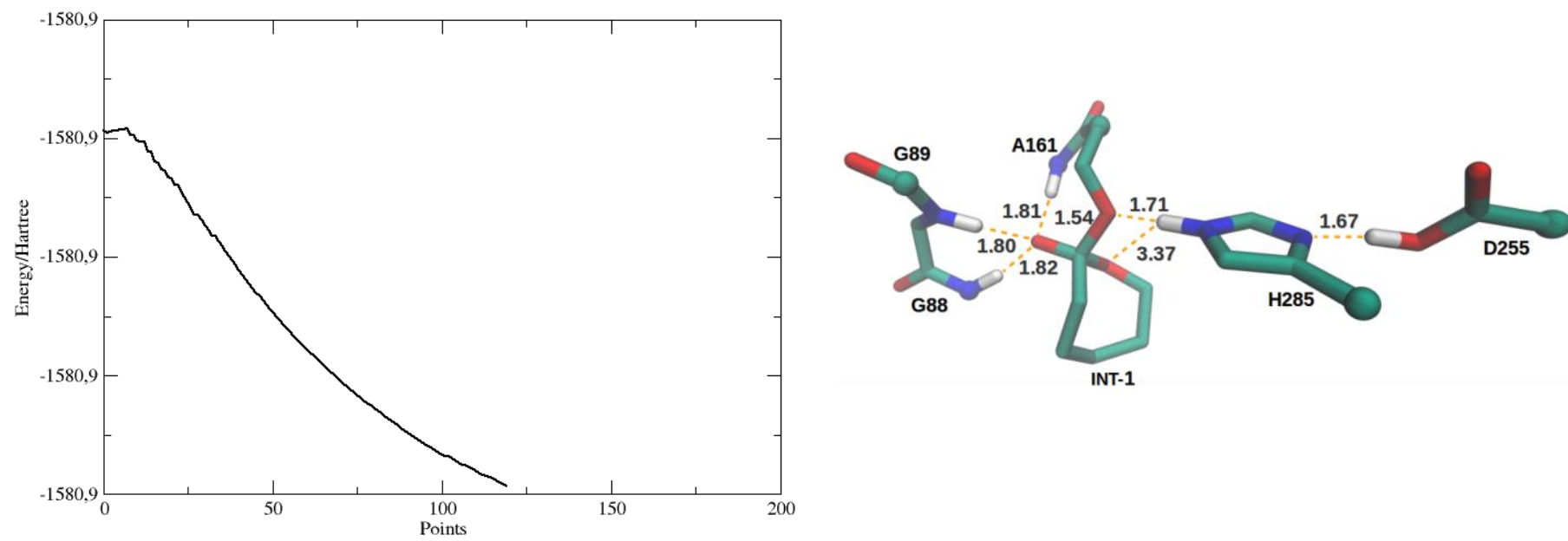

F
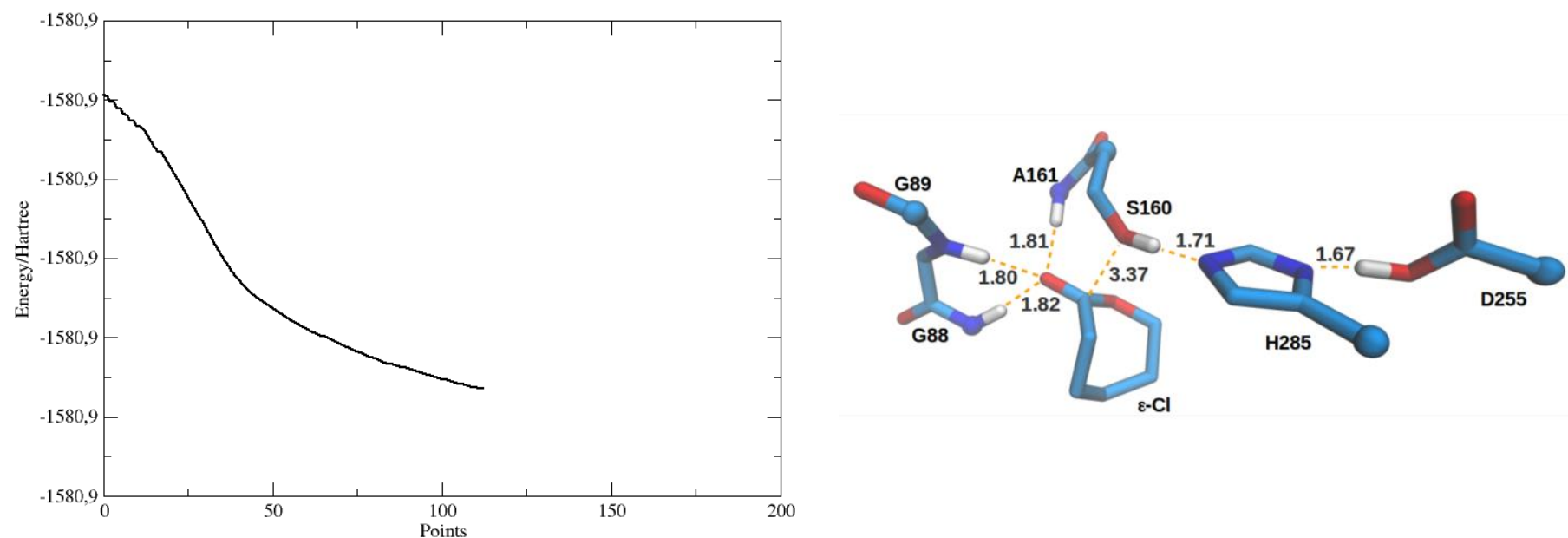


\section{G}
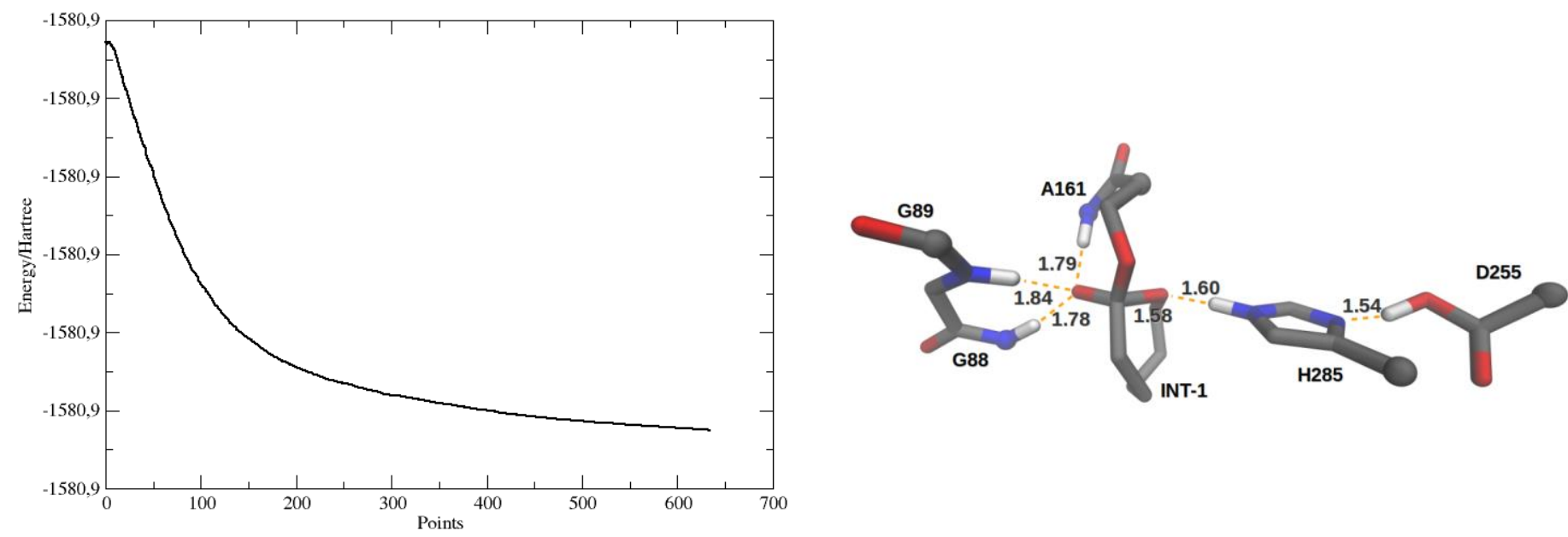

H
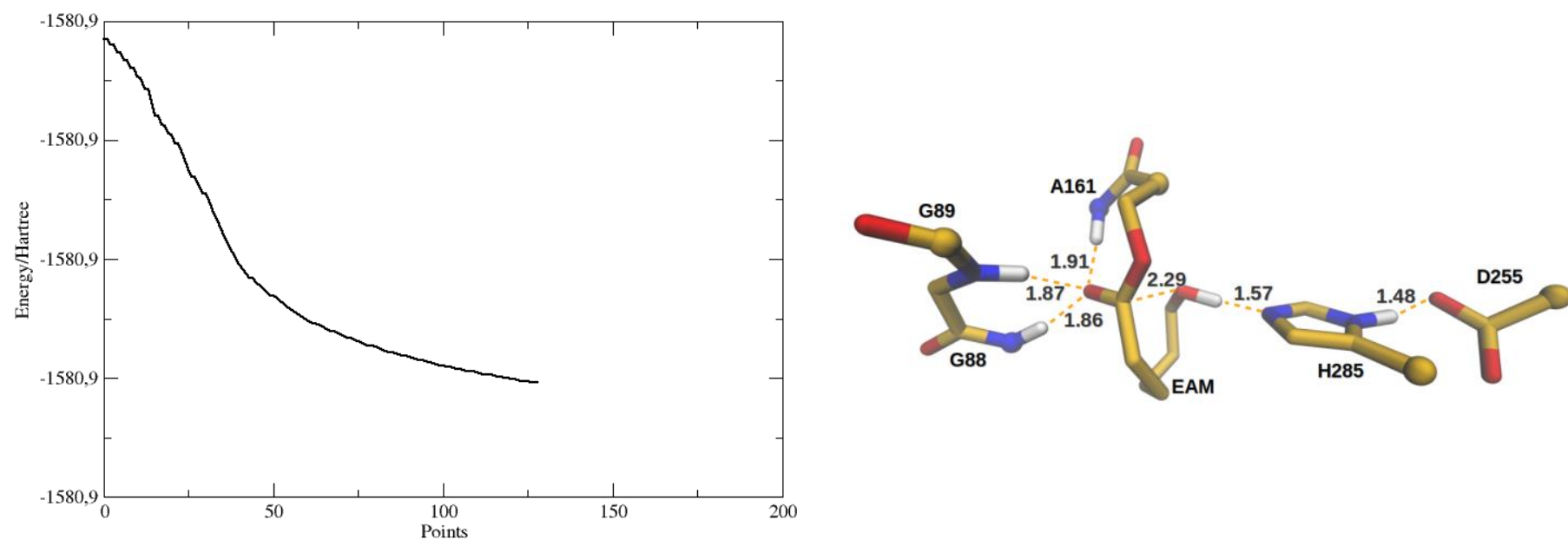

Figure S20. IRC paths of: CalB TS $\mathbf{1}(A, B)$ and $\mathbf{T S}_{\mathbf{2}}(\mathrm{C}, \mathrm{D})$; AfEST $\mathbf{T S}_{\mathbf{1}}(\mathrm{E}, \mathrm{F})$ and $\mathbf{T S}_{\mathbf{2}}(\mathrm{G}, \mathrm{H})$. 
Table S1. RC structure coordinates of CalB.

\begin{tabular}{|c|c|c|c|}
\hline C & 1.497900 & -6.984861 & -1.609146 \\
\hline $\mathrm{O}$ & 1.907743 & -8.132507 & -1.694167 \\
\hline $\mathrm{N}$ & 2.127357 & -5.870285 & -2.093918 \\
\hline $\mathrm{H}$ & 1.565463 & -5.024683 & -2.067152 \\
\hline $\mathrm{C}$ & 3.301012 & -5.880989 & -2.980581 \\
\hline $\mathrm{H}$ & 3.181578 & -6.705704 & -3.694782 \\
\hline $\mathrm{C}$ & 3.487202 & -4.550340 & -3.760666 \\
\hline $\mathrm{H}$ & 3.813011 & -3.761078 & -3.062061 \\
\hline $\mathrm{O}$ & 2.329066 & -4.153031 & -4.469728 \\
\hline $\mathrm{H}$ & 1.707251 & -3.766336 & -3.826066 \\
\hline $\mathrm{C}$ & -3.561731 & -3.793040 & 0.041060 \\
\hline $\mathrm{O}$ & -2.453034 & -4.270124 & -0.171589 \\
\hline $\mathrm{N}$ & -4.114751 & -2.768583 & -0.654878 \\
\hline $\mathrm{H}$ & -4.961951 & -2.384180 & -0.260138 \\
\hline $\mathrm{C}$ & -3.370866 & -1.850723 & -1.537404 \\
\hline $\mathrm{H}$ & -4.066661 & -1.031828 & -1.726326 \\
\hline $\mathrm{C}$ & -2.109904 & -1.274278 & -0.859554 \\
\hline $\mathrm{H}$ & -1.323939 & -2.023508 & -0.929704 \\
\hline $\mathrm{H}$ & -1.790507 & -0.397071 & -1.442279 \\
\hline $\mathrm{O}$ & -2.405013 & -0.962526 & 0.486848 \\
\hline $\mathrm{H}$ & -1.734183 & -0.361975 & 0.888555 \\
\hline $\mathrm{C}$ & -3.128734 & -2.448278 & -2.964004 \\
\hline $\mathrm{O}$ & -3.889579 & -2.133840 & -3.872523 \\
\hline $\mathrm{N}$ & -2.050703 & -3.261122 & -3.153397 \\
\hline $\mathrm{H}$ & -1.530848 & -3.653061 & -2.378279 \\
\hline $\mathrm{C}$ & -0.676630 & 7.253219 & 1.808650 \\
\hline $\mathrm{H}$ & -1.017495 & 7.542070 & 0.808200 \\
\hline $\mathrm{H}$ & 0.125827 & 7.923439 & 2.142821 \\
\hline $\mathrm{C}$ & -0.198672 & 5.788501 & 1.831165 \\
\hline $\mathrm{O}$ & 0.415391 & 5.452729 & 2.903540 \\
\hline $\mathrm{O}$ & -0.464955 & 5.057276 & 0.856304 \\
\hline $\mathrm{C}$ & 0.897279 & 2.531774 & 5.286959 \\
\hline $\mathrm{H}$ & 1.992598 & 2.423324 & 5.316510 \\
\hline $\mathrm{H}$ & 0.493247 & 1.934386 & 6.114382 \\
\hline $\mathrm{C}$ & 0.339982 & 2.039976 & 3.971761 \\
\hline $\mathrm{N}$ & 0.247248 & 2.854867 & 2.872094 \\
\hline $\mathrm{H}$ & 0.404209 & 3.931891 & 2.853393 \\
\hline $\mathrm{C}$ & -0.238686 & 2.117723 & 1.852826 \\
\hline $\mathrm{H}$ & -0.442552 & 2.578888 & 0.896430 \\
\hline $\mathrm{N}$ & -0.460873 & 0.847645 & 2.200975 \\
\hline $\mathrm{C}$ & -0.096831 & 0.797864 & 3.539579 \\
\hline $\mathrm{H}$ & -0.179243 & -0.119649 & 4.111296 \\
\hline $\mathrm{O}$ & 1.216201 & -1.558388 & -1.367300 \\
\hline $\mathrm{O}$ & 0.562211 & -3.532586 & -2.065806 \\
\hline $\mathrm{C}$ & 2.132946 & -1.779194 & 1.725813 \\
\hline $\mathrm{C}$ & 1.800604 & -3.175700 & 1.183862 \\
\hline $\mathrm{C}$ & 2.423217 & -0.729812 & 0.647132 \\
\hline $\mathrm{C}$ & 0.516700 & -3.210715 & 0.322955 \\
\hline $\mathrm{C}$ & 1.275893 & -0.526571 & -0.332451 \\
\hline $\mathrm{C}$ & 0.754816 & -2.778000 & -1.108194 \\
\hline $\mathrm{H}$ & 1.287133 & -1.415465 & 2.323619 \\
\hline $\mathrm{H}$ & 2.997695 & -1.850145 & 2.398441 \\
\hline $\mathrm{H}$ & 1.643541 & -3.855691 & 2.029592 \\
\hline $\mathrm{H}$ & 2.644764 & -3.581753 & 0.608158 \\
\hline $\mathrm{H}$ & 2.592257 & 0.237102 & 1.135907 \\
\hline $\mathrm{H}$ & 3.331441 & -0.981287 & 0.081094 \\
\hline $\mathrm{H}$ & -0.246951 & -2.567679 & 0.780430 \\
\hline $\mathrm{H}$ & 0.091702 & -4.214084 & 0.271986 \\
\hline $\mathrm{H}$ & 0.322101 & -0.471837 & 0.196654 \\
\hline $\mathrm{H}$ & 1.409499 & 0.389857 & -0.909477 \\
\hline $\mathrm{H}$ & 0.551216 & -6.716058 & -1.097488 \\
\hline $\mathrm{H}$ & 4.287237 & -4.702819 & -4.493351 \\
\hline $\mathrm{H}$ & 4.212899 & -6.083746 & -2.400150 \\
\hline $\mathrm{H}$ & -4.243473 & -4.192769 & 0.816337 \\
\hline $\mathrm{H}$ & -1.937186 & -3.669842 & -4.070528 \\
\hline $\mathrm{H}$ & -1.509559 & 7.370381 & 2.516333 \\
\hline $\mathrm{H}$ & 0.689199 & 3.600580 & 5.503210 \\
\hline
\end{tabular}

Table S2. TS 1 structure coordinates of CalB.

$$
\text { C } \quad 0.484707 \quad 2.507913 \quad-4.806968
$$

$\begin{array}{llll}\mathrm{O} & 0.543312 & 2.628209 & -6.060135\end{array}$

$\begin{array}{llll}\mathrm{N} & 1.557960 & 2.776208 & -3.986143\end{array}$

$\begin{array}{llll}\mathrm{H} & 1.444794 & 2.423704 & -3.036274\end{array}$

C $\quad 2.931159 \quad 3.135683 \quad-4.445506$

$\begin{array}{llll}\mathrm{H} & 2.827424 & 3.532327 & -5.458344\end{array}$

C $\quad 3.503854 \quad 4.181564 \quad-3.491970$

H $\quad 3.582416 \quad 3.739667 \quad-2.481856$

$\begin{array}{llll}\mathrm{O} & 2.731040 & 5.368051 & -3.475570\end{array}$

$\begin{array}{llll}\mathrm{H} & 1.804001 & 5.077028 & -3.426532\end{array}$

$\begin{array}{llll}\text { C } & -4.359657 & 1.785591 & -0.817785\end{array}$

$\begin{array}{llll}\mathrm{O} & -5.112159 & 2.440321 & -0.110523\end{array}$

$\begin{array}{llll}\mathrm{N} & -3.068039 & 1.474396 & -0.539370\end{array}$

$\begin{array}{llll}\mathrm{H} & -2.573162 & 0.790034 & -1.107056\end{array}$

$\begin{array}{llll}\text { C } & -2.439283 & 1.719929 & 0.746491\end{array}$

$\begin{array}{llll}\mathrm{H} & -3.220172 & 1.837379 & 1.502081\end{array}$

$\begin{array}{llll}\text { C } & -1.561502 & 0.474262 & 1.095529\end{array}$

$\begin{array}{llll}\mathrm{H} & -0.763213 & 0.797024 & 1.781830\end{array}$

$\begin{array}{llll}\mathrm{H} & -2.197542 & -0.247010 & 1.633326\end{array}$

$\begin{array}{llll}\mathrm{O} & -1.045576 & -0.140532 & -0.057180\end{array}$

$\begin{array}{llll}\text { C } & -1.603631 & 3.007622 & 0.854846\end{array}$

$\begin{array}{llll}\mathrm{O} & -1.497168 & 3.575951 & 1.936084\end{array}$

$\begin{array}{llll}\text { O } & 1.205085 & 1.204063 & 0.296687\end{array}$

$\begin{array}{llll}\mathrm{O} & 0.374862 & 1.373280 & -1.818098\end{array}$

$\begin{array}{llll}\text { C } & 3.581842 & 0.838994 & -1.370228\end{array}$

$\begin{array}{llll}\text { C } & 2.981951 & -0.546498 & -1.028144\end{array}$

$\begin{array}{llll}\text { C } & 3.496168 & 1.856701 & -0.210500\end{array}$

$\begin{array}{llll}\text { C } & 1.439373 & -0.685176 & -1.167121\end{array}$

$\begin{array}{llll}\text { C } & 2.079972 & 2.328845 & 0.133497\end{array}$

$\begin{array}{llll}\text { C } & 0.790656 & 0.655702 & -0.905273\end{array}$

$\begin{array}{llll}\mathrm{H} & 4.644018 & 0.705508 & -1.612857\end{array}$

$\begin{array}{llll}\mathrm{H} & 3.104331 & 1.242433 & -2.273170\end{array}$

$\begin{array}{llll}\mathrm{H} & 3.265031 & -0.789300 & 0.002970\end{array}$

$\begin{array}{llll}\mathrm{H} & 3.443958 & -1.305357 & -1.671177\end{array}$

$\begin{array}{llll}\mathrm{H} & 3.939394 & 1.391228 & 0.680040\end{array}$

$\begin{array}{llll}\mathrm{H} & 4.101118 & 2.744120 & -0.447908\end{array}$

$\mathrm{H} \quad 1.082206 \quad-1.438506 \quad-0.464408$

$\begin{array}{llll}\mathrm{H} & 1.158678 & -0.988028 & -2.180679\end{array}$

$\begin{array}{llll}\mathrm{H} & 2.059127 & 2.864362 & 1.086634\end{array}$

$\begin{array}{llll}\mathrm{H} & 1.689329 & 2.995469 & -0.644522\end{array}$

$\begin{array}{llll}\mathrm{N} & -0.983541 & 3.447851 & -0.281272\end{array}$

$\begin{array}{llll}\mathrm{H} & -0.750959 & 2.767150 & -1.002745\end{array}$

C $\begin{array}{llll}-1.143856 & -6.453391 & 6.423067\end{array}$

$\begin{array}{llll}\mathrm{H} & -2.194602 & -6.652686 & 6.176599\end{array}$

$\begin{array}{llll}\mathrm{H} & -1.136316 & -5.731045 & 7.247762\end{array}$

C $\quad-0.447543 \quad-5.871511 \quad 5.203452$

$\begin{array}{llll}\text { O } & 0.415779 & -6.477767 & 4.585215\end{array}$

$\begin{array}{llll}\mathrm{O} & -0.920475 & -4.673715 & 4.913472\end{array}$

C $\quad-0.792693 \quad-6.089091 \quad 1.581311$

$\begin{array}{llll}\mathrm{H} & 0.033914 & -6.463617 & 2.193140\end{array}$

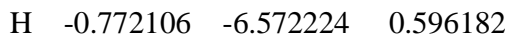

$\begin{array}{llll}\text { C } & -0.712917 & -4.594889 & 1.443803\end{array}$

$\begin{array}{llll}\mathrm{N} & -0.433011 & -3.799388 & 2.533540\end{array}$

$\begin{array}{llll}\mathrm{H} & -0.581830 & -4.327865 & 3.976796\end{array}$

$\begin{array}{llll}\text { C } & -0.471434 & -2.546769 & 2.081531\end{array}$

$\begin{array}{llll}\mathrm{H} & -0.300781 & -1.671350 & 2.695427\end{array}$

$\begin{array}{llll}\mathrm{N} & -0.750013 & -2.464289 & 0.766478\end{array}$

$\begin{array}{llll}\mathrm{H} & -0.919437 & -1.320696 & 0.234201\end{array}$

$\begin{array}{llll}\text { C } & -0.906897 & -3.771626 & 0.352591\end{array}$

H $\quad-1.138712 \quad-4.018228 \quad-0.675515$

$\begin{array}{llll}\mathrm{H} & -0.406869 & 2.179244 & -4.250508\end{array}$

$\begin{array}{llll}\mathrm{H} & 4.514688 & 4.461153 & -3.811503\end{array}$

$\begin{array}{llll}\mathrm{H} & 3.572987 & 2.243529 & -4.471954\end{array}$

$\begin{array}{llll}\mathrm{H} & -4.671022 & 1.376908 & -1.802392\end{array}$

$\mathrm{H} \quad-0.284893 \quad 4.161234 \quad-0.113735$

$\begin{array}{llll}\mathrm{H} & -0.656697 & -7.383305 & 6.728567\end{array}$ 


\section{H $\quad-1.722016 \quad-6.394116 \quad 2.085353$}

Table S3. INT-1 structure coordinates of CalB.

C $\quad 0.776455 \quad 3.753976 \quad-5.579862$

$\begin{array}{llll}\mathrm{O} & 0.870277 & 4.305194 & -6.711599\end{array}$

$\begin{array}{llll}\mathrm{N} & 1.869883 & 3.540841 & -4.788158\end{array}$

$\begin{array}{llll}\mathrm{H} & 1.635474 & 3.245075 & -3.827968\end{array}$

$\begin{array}{llll}\text { C } & 3.263027 & 4.063883 & -5.037106\end{array}$

$\begin{array}{llll}\mathrm{H} & 3.197395 & 5.114991 & -5.338698\end{array}$

C $\quad 4.077238 \quad 3.919876 \quad-3.693004$

$\mathrm{H} \quad 4.264749 \quad 2.853613 \quad-3.497048$

$\begin{array}{llll}\mathrm{O} & 3.463156 & 4.551010 & -2.591840\end{array}$

$\mathrm{H} \quad 2.644463 \quad 4.055402 \quad-2.360721$

$\begin{array}{llll}\text { C } & -4.190958 & 2.987319 & -1.633970\end{array}$

$\begin{array}{llll}\mathrm{O} & -4.983833 & 3.311145 & -0.762824\end{array}$

$\begin{array}{llll}\mathrm{N} & -2.888028 & 2.663280 & -1.450260\end{array}$

$\mathrm{H} \quad-2.305784 \quad 2.426896 \quad-2.244264$

$\begin{array}{llll}\text { C } & -2.198507 & 2.735353 & -0.171000\end{array}$

$\begin{array}{llll}\mathrm{H} & -2.914298 & 2.490459 & 0.617238\end{array}$

$\begin{array}{llll}\text { C } & -1.033353 & 1.709107 & -0.165206\end{array}$

$\begin{array}{llll}\mathrm{H} & -0.240368 & 2.053393 & 0.505572\end{array}$

$\begin{array}{llll}\mathrm{H} & -1.411298 & 0.749617 & 0.208667\end{array}$

$\begin{array}{llll}\mathrm{O} & -0.532277 & 1.477152 & -1.475442\end{array}$

$\begin{array}{llll}\text { C } & -1.701743 & 4.156289 & 0.151113\end{array}$

$\begin{array}{llll}\mathrm{O} & -2.119220 & 4.777775 & 1.122710\end{array}$

$\begin{array}{llll}\mathrm{O} & 1.616183 & 1.285517 & -0.654716\end{array}$

$\begin{array}{llll}\text { O } & 1.103391 & 2.996343 & -2.152875\end{array}$

$\begin{array}{llll}\text { C } & 3.288967 & -0.368673 & -2.282697\end{array}$

$\begin{array}{llll}\text { C } & 2.528154 & 0.424950 & -3.361825\end{array}$

$\begin{array}{llll}\text { C } & 3.891467 & 0.457120 & -1.128754\end{array}$

$\begin{array}{llll}\text { C } & 1.070170 & 0.719936 & -2.990138\end{array}$

$\begin{array}{llll}\text { C } & 3.002032 & 1.609171 & -0.632866\end{array}$

$\begin{array}{llll}\text { C } & 0.853171 & 1.747757 & -1.855238\end{array}$

$\mathrm{H} \quad 2.599942 \quad-1.112995 \quad-1.861785$

$\mathrm{H} \quad 4.103684 \quad-0.939120 \quad-2.748858$

$\begin{array}{llll}\mathrm{H} & 2.517854 & -0.167380 & -4.286441\end{array}$

$\begin{array}{llll}\mathrm{H} & 3.049637 & 1.354436 & -3.604584\end{array}$

$\mathrm{H} \quad 4.119163 \quad-0.228310 \quad-0.301141$

$\begin{array}{llll}\mathrm{H} & 4.848707 & 0.895377 & -1.446271\end{array}$

$\begin{array}{llll}\mathrm{H} & 0.588922 & -0.221934 & -2.698821\end{array}$

$\begin{array}{llll}\mathrm{H} & 0.536463 & 1.103736 & -3.867724\end{array}$

$\begin{array}{llll}\mathrm{H} & 3.256892 & 1.860381 & 0.404433\end{array}$

$\mathrm{H} \quad 3.164622 \quad 2.506335 \quad-1.231794$

$\begin{array}{llll}\mathrm{N} & -0.780840 & 4.635521 & -0.722050\end{array}$

$\begin{array}{llll}\mathrm{H} & -0.208917 & 4.023326 & -1.324089\end{array}$

$\begin{array}{llll}\text { C } & -0.772600 & -5.092690 & 5.788190\end{array}$

$\begin{array}{llll}\mathrm{H} & -1.142688 & -4.423343 & 6.573906\end{array}$

$\begin{array}{llll}\mathrm{H} & -0.029057 & -5.780586 & 6.198254\end{array}$

C $\quad-0.165112 \quad-4.285225 \quad 4.658440$

$\begin{array}{llll}\text { O } & 0.969199 & -4.464500 & 4.244773\end{array}$

$\begin{array}{llll}\text { O } & -1.028876 & -3.394591 & 4.186631\end{array}$

$\begin{array}{llll}\text { C } & 0.031150 & -4.574479 & 1.102970\end{array}$

$\begin{array}{llll}\mathrm{H} & 0.615254 & -4.976369 & 1.938399\end{array}$

$\begin{array}{llll}\mathrm{H} & 0.322738 & -5.087645 & 0.178992\end{array}$

$\begin{array}{llll}\text { C } & 0.249314 & -3.103408 & 0.980558\end{array}$

$\begin{array}{llll}\mathrm{N} & -0.080620 & -2.245152 & 2.008123\end{array}$

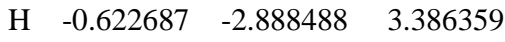

$\begin{array}{llll}\text { C } & 0.252198 & -1.032230 & 1.598497\end{array}$

$\begin{array}{llll}\mathrm{H} & 0.128243 & -0.117197 & 2.160094\end{array}$

$\begin{array}{llll}\mathrm{N} & 0.778148 & -1.060371 & 0.356660\end{array}$

$\begin{array}{llll}\mathrm{H} & 1.116932 & -0.222570 & -0.151721\end{array}$

C $\quad 0.782587 \quad-2.373725 \quad-0.054203$

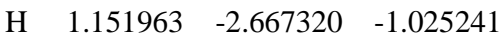

$\begin{array}{llll}\mathrm{H} & -0.166013 & 3.394432 & -5.132936\end{array}$

$\begin{array}{llll}\mathrm{H} & 5.051301 & 4.403142 & -3.839314\end{array}$

H $\quad 3.741909 \quad 3.492669 \quad-5.842016$

$\mathrm{H} \quad-4.478012 \quad 2.902550 \quad-2.703954$

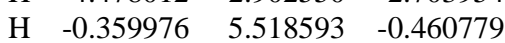

$\begin{array}{llll}\mathrm{H} & -1.634937 & -5.657244 & 5.412197\end{array}$

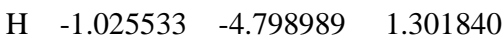

Table S4. TS 2 structure coordinates of CalB.

C $\quad 0.066227 \quad 2.917050 \quad-4.900265$

$\begin{array}{llll}\mathrm{O} & -0.107230 & 3.329949 & -6.035419\end{array}$

$\begin{array}{llll}\mathrm{N} & 1.277387 & 2.814730 & -4.237295\end{array}$

$\begin{array}{llll}\mathrm{H} & 1.173781 & 2.533526 & -3.264337\end{array}$

C $\quad 2.655286 \quad 3.291448 \quad-4.617301$

$\begin{array}{llll}\mathrm{H} & 2.636517 & 4.382624 & -4.730759\end{array}$

$\begin{array}{llll}\text { C } & 3.664377 & 2.894332 & -3.543716\end{array}$

$\begin{array}{llll}\mathrm{H} & 3.795356 & 1.804443 & -3.540992\end{array}$

$\begin{array}{llll}\text { O } & 3.348947 & 3.385068 & -2.252991\end{array}$

$\begin{array}{llll}\mathrm{H} & 2.619461 & 2.858905 & -1.871661\end{array}$

C $\quad-4.561657 \quad 2.178433 \quad-0.652654$

$\begin{array}{llll}\mathrm{O} & -5.214418 & 2.737362 & 0.212271\end{array}$

$\begin{array}{llll}\mathrm{N} & -3.286724 & 1.725539 & -0.522015\end{array}$

$\begin{array}{llll}\mathrm{H} & -2.816440 & 1.325142 & -1.323524\end{array}$

$\begin{array}{llll}\text { C } & -2.470668 & 1.946749 & 0.663358\end{array}$

$\begin{array}{llll}\mathrm{H} & -3.089317 & 1.767372 & 1.546862\end{array}$

$\begin{array}{llll}\text { C } & -1.290081 & 0.948907 & 0.678021\end{array}$

$\begin{array}{llll}\mathrm{H} & -0.434896 & 1.341710 & 1.228234\end{array}$

$\begin{array}{llll}\mathrm{H} & -1.612127 & 0.019015 & 1.152088\end{array}$

$\begin{array}{lllll}\mathrm{O} & -0.867822 & 0.559596 & -0.645376\end{array}$

$\begin{array}{llll}\text { C } & -2.002804 & 3.407866 & 0.804782\end{array}$

$\begin{array}{llll}\mathrm{O} & -2.359186 & 4.111359 & 1.739127\end{array}$

$\begin{array}{llll}\mathrm{O} & 1.377756 & 0.150965 & 0.618738\end{array}$

$\begin{array}{llll}\mathrm{O} & 0.826131 & 1.928464 & -1.341792\end{array}$

C $3.428295 \quad-0.142081 \quad-1.689526$

$\begin{array}{llll}\text { C } & 2.206645 & -0.496534 & -2.564458\end{array}$

$\begin{array}{llll}\text { C } & 3.506048 & -0.731146 & -0.271450\end{array}$

$\begin{array}{llll}\text { C } & 0.799907 & -0.449563 & -1.949866\end{array}$

$\begin{array}{llll}\text { C } & 2.768346 & 0.120693 & 0.774256\end{array}$

$\begin{array}{llll}\text { C } & 0.406367 & 0.776418 & -1.145088\end{array}$

H $\quad 4.315588 \quad-0.452186 \quad-2.260190$

$\begin{array}{llll}\mathrm{H} & 3.507647 & 0.944961 & -1.588336\end{array}$

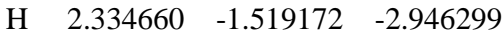

$\begin{array}{llll}\mathrm{H} & 2.226998 & 0.150936 & -3.450311\end{array}$

H $\quad 3.127455 \quad-1.762511 \quad-0.245117$

$\begin{array}{llll}\mathrm{H} & 4.563951 & -0.785099 & 0.026455\end{array}$

H $\quad 0.611025 \quad-1.318014 \quad-1.319286$

$\begin{array}{llll}\mathrm{H} & 0.066834 & -0.513489 & -2.770271\end{array}$

$\begin{array}{llll}\mathrm{H} & 3.014028 & -0.268896 & 1.779305\end{array}$

$\begin{array}{llll}\mathrm{H} & 3.170757 & 1.148082 & 0.730353\end{array}$

$\begin{array}{llll}\mathrm{N} & -1.184202 & 3.836034 & -0.198043\end{array}$

H $\quad-0.593879 \quad 3.176673 \quad-0.707566$

$\begin{array}{llll}\text { C } & -1.042820 & -6.087691 & 6.442765\end{array}$

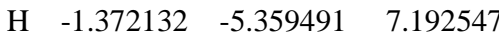

$\begin{array}{llll}\mathrm{H} & -0.215743 & -6.679561 & 6.840220\end{array}$

C $\quad-0.620623 \quad-5.380597 \quad 5.175925$

$\begin{array}{llll}\text { O } & 0.490939 & -5.526950 & 4.686398\end{array}$

$\begin{array}{llll}\mathrm{O} & -1.594675 & -4.629262 & 4.695718\end{array}$

C $\quad-0.196554 \quad-5.648448 \quad 1.488090$

$\begin{array}{llll}\mathrm{H} & 0.222951 & -6.111234 & 2.387481\end{array}$

$\begin{array}{llll}\mathrm{H} & 0.353386 & -6.017696 & 0.614555\end{array}$

$\begin{array}{llll}\text { C } & -0.105150 & -4.160982 & 1.580993\end{array}$

$\begin{array}{llll}\mathrm{N} & -0.755553 & -3.461678 & 2.570907\end{array}$

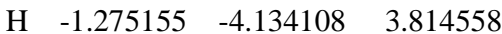

$\begin{array}{llll}\text { C } & -0.403656 & -2.187682 & 2.402879\end{array}$

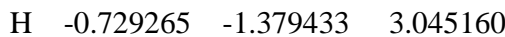

$\begin{array}{llll}\mathrm{N} & 0.421549 & -2.007699 & 1.358681\end{array}$

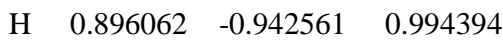

C $\quad 0.616001 \quad-3.262619 \quad 0.826926$

$\mathrm{H} \quad 1.252754 \quad-3.426460 \quad-0.032138$

$\begin{array}{llll}\mathrm{H} & -0.756157 & 2.546608 & -4.256648\end{array}$

$\begin{array}{llll}\mathrm{H} & 4.631118 & 3.335609 & -3.813686\end{array}$

$\mathrm{H} \quad 2.931534 \quad 2.855368 \quad-5.584211$

$\begin{array}{llll}\mathrm{H} & -4.968613 & 1.956076 & -1.661597\end{array}$ 


$\begin{array}{rrrr}\mathrm{H} & -0.766894 & 4.744989 & -0.037109 \\ \mathrm{H} & -1.897931 & -6.742229 & 6.237629 \\ \mathrm{H} & -1.237635 & -5.985333 & 1.393988\end{array}$

Table S5. EAM structure coordinates of CalB.

\begin{tabular}{|c|c|c|c|}
\hline & & & \\
\hline & -1.446093 & & \\
\hline & & & \\
\hline & -0.970798 & & \\
\hline & -0.830910 & & \\
\hline & -1.608771 & & \\
\hline & -1.023216 & & \\
\hline & & & \\
\hline & -2.140483 & & \\
\hline & & & \\
\hline & & & \\
\hline & & & \\
\hline & & & \\
\hline & & & \\
\hline & & & \\
\hline & & & \\
\hline & & & \\
\hline & & & \\
\hline & & & \\
\hline & & & \\
\hline & & & \\
\hline & & & \\
\hline & & & \\
\hline $\mathrm{O}$ & & & \\
\hline & & & \\
\hline & & & \\
\hline & & & \\
\hline & & & \\
\hline & & & \\
\hline & & & \\
\hline & & & \\
\hline & & & \\
\hline & & & \\
\hline & & & \\
\hline & & & \\
\hline & & & \\
\hline & & & \\
\hline & & & \\
\hline & & & \\
\hline & & & \\
\hline & & & \\
\hline $\mathrm{N}$ & & & \\
\hline & & & \\
\hline & & & \\
\hline & & & \\
\hline $\mathrm{H}$ & & & \\
\hline & & & \\
\hline & & & \\
\hline & & & \\
\hline & & & \\
\hline & & & \\
\hline & & & \\
\hline & & & \\
\hline & & & \\
\hline & & & \\
\hline & & & \\
\hline & & & \\
\hline & & & \\
\hline & & & \\
\hline & & & \\
\hline & & & \\
\hline & & & \\
\hline & & & \\
\hline
\end{tabular}

$\begin{array}{rrrr}\mathrm{H} & -3.565316 & 2.194941 & -4.759026 \\ \mathrm{H} & -4.877495 & 2.542647 & 0.367029 \\ \mathrm{H} & 1.435193 & -7.396483 & -2.765408 \\ \mathrm{H} & 4.549474 & -2.169776 & -2.795188\end{array}$

Table S6. EAM with 6-HCA structure of CalB

$\begin{array}{llll}\mathrm{O} & 0.489421 & -3.825483 & -6.961616\end{array}$

$\begin{array}{llll}\mathrm{N} & -0.091357 & -3.787428 & -4.732603\end{array}$

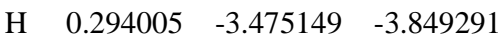

C $\quad-1.415696 \quad-4.455015 \quad-4.689313$

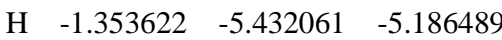

C $\quad-1.837076 \quad-4.625904 \quad-3.234358$

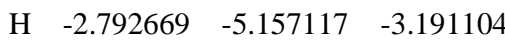

$\begin{array}{llll}\mathrm{O} & -2.051404 & -3.370764 & -2.580362\end{array}$

$\begin{array}{llll}\mathrm{H} & -1.203129 & -2.893294 & -2.559533\end{array}$

C $\quad 6.155660 \quad-2.400231 \quad-3.376340$

O $\quad 5.308422 \quad-2.821756 \quad-4.152834$

$\begin{array}{llll}\mathrm{N} & 6.003505 & -2.367449 & -2.023040\end{array}$

$\mathrm{H} \quad 6.762868 \quad-1.980967 \quad-1.479201$

C $\quad 4.769749 \quad-2.686773 \quad-1.291976$

$\begin{array}{llll}\mathrm{H} & 4.984572 & -2.449477 & -0.248179\end{array}$

$\begin{array}{llll}\text { C } & 3.592821 & -1.799150 & -1.729298\end{array}$

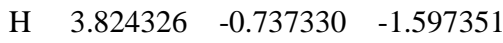

H $\quad 3.280169 \quad-1.987935 \quad-2.755983$

$\begin{array}{llll}\text { O } & 2.528907 & -2.119121 & -0.802138\end{array}$

C $\quad 4.428108 \quad-4.213923 \quad-1.223039$

$\begin{array}{llll}\mathrm{O} & 4.811866 & -4.868174 & -0.265562\end{array}$

$\begin{array}{llll}\mathrm{O} & -0.060740 & -2.877890 & 4.140860\end{array}$

$\begin{array}{llll}\text { O } & 1.048486 & -2.572040 & -2.447852\end{array}$

$\begin{array}{llll}\text { C } & 0.204675 & -5.302025 & 1.203883\end{array}$

$\begin{array}{llll}\text { C } & 0.898538 & -4.647889 & 0.002209\end{array}$

$\begin{array}{llll}\text { C } & 0.570796 & -4.620345 & 2.538682\end{array}$

$\begin{array}{llll}\text { C } & 0.522360 & -3.157423 & -0.167352\end{array}$

$\begin{array}{llll}\text { C } & -0.489745 & -3.621743 & 3.013543\end{array}$

C $\quad 1.360522 \quad-2.573276 \quad-1.267802$

$\begin{array}{llll}\mathrm{H} & -0.886013 & -5.283676 & 1.058375\end{array}$

$\begin{array}{llll}\mathrm{H} & 0.497579 & -6.358801 & 1.228700\end{array}$

$\mathrm{H} \quad 0.645530 \quad-5.179416 \quad-0.924282$

$\begin{array}{llll}\mathrm{H} & 1.984375 & -4.727463 & 0.135538\end{array}$

H $\quad 0.720620 \quad-5.359357 \quad 3.334202$

$\begin{array}{llll}\mathrm{H} & 1.529120 & -4.090193 & 2.426035\end{array}$

$\begin{array}{llll}\mathrm{H} & 0.720574 & -2.611697 & 0.757784\end{array}$

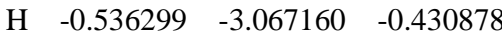

$\begin{array}{llll}\mathrm{H} & -0.796316 & -2.959043 & 2.188916\end{array}$

H $\quad-1.387267 \quad-4.165475 \quad 3.331936$

$\begin{array}{llll}\mathrm{H} & 0.658572 & -2.295369 & 3.851845\end{array}$

$\begin{array}{llll}\mathrm{N} & 3.612160 & -4.739140 & -2.196840\end{array}$

H $\quad 3.628132 \quad-4.285323 \quad-3.106032$

$\begin{array}{llll}\text { C } & 3.995739 & 4.745388 & 5.922698\end{array}$

$\begin{array}{llll}\mathrm{H} & 4.681222 & 4.079692 & 6.461777\end{array}$

$\begin{array}{llll}\mathrm{H} & 3.271238 & 5.189895 & 6.614701\end{array}$

$\begin{array}{llll}\text { C } & 3.271365 & 3.993577 & 4.777245\end{array}$

O $3.981677 \quad 3.111382 \quad 4.185484$

$\begin{array}{llll}\text { O } & 2.104990 & 4.341444 & 4.502414\end{array}$

$\begin{array}{llll}\text { C } & 2.975420 & 5.163804 & 1.552098\end{array}$

$\begin{array}{llll}\mathrm{H} & 2.354772 & 5.110013 & 2.454611\end{array}$

$\begin{array}{llll}\mathrm{H} & 2.552818 & 5.882793 & 0.839292\end{array}$

$\begin{array}{llll}\text { C } & 3.081844 & 3.810188 & 0.921026\end{array}$

$\begin{array}{llll}\mathrm{N} & 3.253616 & 2.679973 & 1.681382\end{array}$

$\begin{array}{llll}\mathrm{H} & 3.430553 & 2.729571 & 2.744094\end{array}$

$\begin{array}{llll}\text { C } & 3.303593 & 1.629400 & 0.827323\end{array}$

$\begin{array}{llll}\mathrm{H} & 3.423451 & 0.608890 & 1.171392\end{array}$

$\begin{array}{llll}\mathrm{N} & 3.179833 & 1.991058 & -0.446250\end{array}$

$\begin{array}{llll}\text { C } & 3.043909 & 3.368773 & -0.385977\end{array}$

$\begin{array}{llll}\mathrm{H} & 2.930614 & 3.966656 & -1.284245\end{array}$

$\mathrm{H} \quad 1.520440 \quad 2.335817 \quad-1.951705$

$\begin{array}{llll}\mathrm{O} & 0.762501 & 1.920901 & -2.402044\end{array}$ 


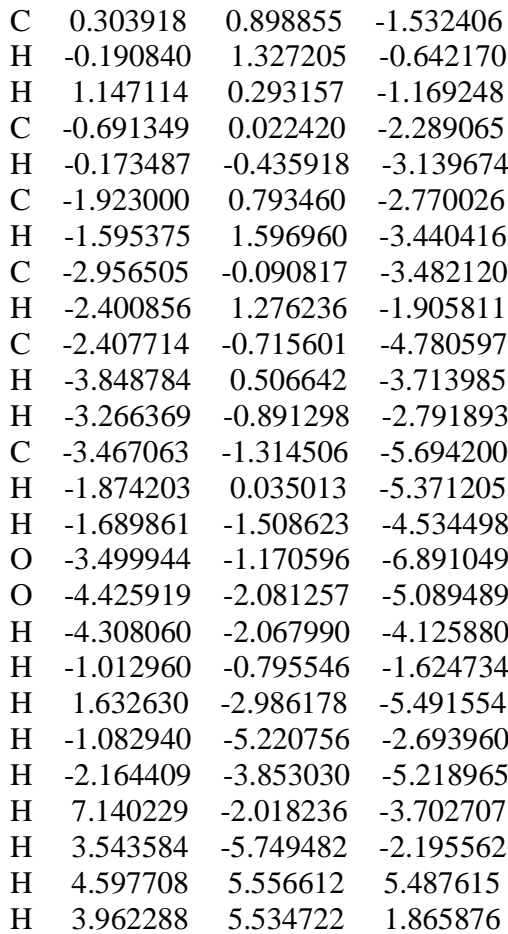

Table S7. INT-2 structure coordinates of CalB.

$\begin{array}{cccc}\mathrm{C} & -6.194660 & -1.843297 & -2.576691 \\ \mathrm{O} & -7.245062 & -1.764598 & -3.206214 \\ \mathrm{~N} & -5.944428 & -1.221964 & -1.383146 \\ \mathrm{H} & -4.939493 & -1.282350 & -1.163971 \\ \mathrm{C} & -6.832058 & -0.231007 & -0.789082 \\ \mathrm{H} & -7.784174 & -0.683444 & -0.545057 \\ \mathrm{C} & -6.330148 & 0.303782 & 0.552337 \\ \mathrm{H} & -5.430531 & 0.927702 & 0.406469 \\ \mathrm{O} & -6.075312 & -0.732259 & 1.491036 \\ \mathrm{H} & -5.552729 & -1.404924 & 1.024430 \\ \mathrm{C} & -1.361521 & -5.384824 & -3.038433 \\ \mathrm{O} & -0.710982 & -6.367901 & -2.714287 \\ \mathrm{~N} & -1.503205 & -4.241811 & -2.314305 \\ \mathrm{H} & -2.162424 & -3.525231 & -2.612799 \\ \mathrm{C} & -1.028440 & -4.119623 & -0.946068 \\ \mathrm{H} & -0.167806 & -4.780916 & -0.829318 \\ \mathrm{C} & -0.590391 & -2.653705 & -0.646769 \\ \mathrm{H} & -0.735013 & -2.441872 & 0.422093 \\ \mathrm{H} & 0.480905 & -2.569546 & -0.861583 \\ \mathrm{O} & -1.178279 & -1.667328 & -1.465589 \\ \mathrm{C} & -2.052559 & -4.579723 & 0.104337 \\ \mathrm{O} & -1.723403 & -5.302023 & 1.042515 \\ \mathrm{O} & 0.092219 & 0.193300 & 4.921188 \\ \mathrm{O} & -2.320861 & -0.039402 & -2.298863 \\ \mathrm{C} & -1.722537 & 1.247422 & 1.746630 \\ \mathrm{C} & -1.749682 & 0.748465 & 0.298267 \\ \mathrm{C} & -0.870340 & 0.368608 & 2.665457 \\ \mathrm{C} & -2.640035 & -0.479230 & 0.084912 \\ \mathrm{C} & -0.815405 & 0.909270 & 4.090635 \\ \mathrm{C} & -2.501855 & -1.105399 & -1.322859 \\ \mathrm{H} & -1.315265 & 2.268652 & 1.771984 \\ \mathrm{H} & -2.749570 & 1.307402 & 2.138323 \\ \mathrm{H} & -0.728183 & 0.517040 & -0.030378 \\ \mathrm{H} & -2.102564 & 1.550103 & -0.359074 \\ \mathrm{H} & -1.265729 & -0.658693 & 2.680650 \\ \mathrm{H} & 0.154781 & 0.313071 & 2.274681 \\ \mathrm{H} & -3.686756 & -0.198721 & 0.242646 \\ \mathrm{H} & -2.430268 & -1.262275 & 0.823984 \\ \mathrm{H} & -0.452045 & 1.943903 & 4.080662 \\ \mathrm{H} & -1.830842 & 0.921348 & 4.524541\end{array}$

\begin{tabular}{|c|c|c|c|}
\hline & & & \\
\hline & & -1.953591 & \\
\hline & & & \\
\hline & -4.256766 & & \\
\hline & -3.910007 & 1.170379 & \\
\hline & -3.084425 & & \\
\hline & -3.975244 & & \\
\hline & -2.016412 & & \\
\hline & -1.240578 & & \\
\hline & -1.369117 & & \\
\hline & -2.456274 & & \\
\hline & -0.16 & & \\
\hline & -2.10 & & \\
\hline & & & \\
\hline & & & \\
\hline & & & \\
\hline & -0.4 & & \\
\hline & & & \\
\hline & & & \\
\hline & & & \\
\hline & & & \\
\hline & -3. & & \\
\hline & & & \\
\hline & & & \\
\hline & & & \\
\hline & & & \\
\hline & & & \\
\hline & & & \\
\hline & & & \\
\hline & & & \\
\hline & & & \\
\hline & & & \\
\hline & & & \\
\hline & & & \\
\hline & & & \\
\hline & & & \\
\hline & & & \\
\hline & & & \\
\hline & & & \\
\hline & & & \\
\hline & & & \\
\hline & & & \\
\hline & & & \\
\hline & & & \\
\hline & & & \\
\hline & -3.9 & & \\
\hline & & & \\
\hline & 3.875 & 1.706665 & -4.10 \\
\hline
\end{tabular}

Table S8. PC structure coordinates of CalB.

$\begin{array}{llll}\mathrm{C} & -0.423868 & -3.825688 & -4.913184 \\ \mathrm{O} & -0.552303 & -4.448195 & -5.955106 \\ \mathrm{~N} & -1.075719 & -4.117641 & -3.740679 \\ \mathrm{H} & -1.099450 & -3.359118 & -3.063635 \\ \mathrm{C} & -2.140690 & -5.112436 & -3.725130 \\ \mathrm{H} & -1.803442 & -5.951142 & -4.340930 \\ \mathrm{C} & -2.461283 & -5.596058 & -2.311814 \\ \mathrm{H} & -2.866532 & -4.753290 & -1.720331 \\ \mathrm{O} & -1.338400 & -6.172918 & -1.665281 \\ \mathrm{H} & -0.585449 & -5.586095 & -1.848401 \\ \mathrm{C} & 4.619310 & -1.489040 & -3.809811 \\ \mathrm{O} & 4.357249 & -2.597408 & -4.241971 \\ \mathrm{~N} & 4.474952 & -1.076973 & -2.520702 \\ \mathrm{H} & 4.708089 & -0.115034 & -2.315619 \\ \mathrm{C} & 3.929847 & -1.870257 & -1.418955 \\ \mathrm{H} & 4.418337 & -1.499198 & -0.510812 \\ \mathrm{C} & 2.425978 & -1.649107 & -1.213087 \\ \mathrm{H} & 2.150737 & -2.121655 & -0.255261\end{array}$




\begin{tabular}{|c|c|c|c|}
\hline & & & \\
\hline & & & \\
\hline & .756978 & -1.886804 & \\
\hline & 4.414943 & -3.346036 & \\
\hline & & & \\
\hline & 3.439540 & -4.285070 & \\
\hline & 2.595226 & & \\
\hline & 2.248700 & & \\
\hline & & & \\
\hline & & & \\
\hline & & & \\
\hline & & & \\
\hline & & & \\
\hline & & & \\
\hline & & & \\
\hline & & & \\
\hline & & & \\
\hline & & & \\
\hline & & & \\
\hline & & & \\
\hline & & & \\
\hline & & & \\
\hline & & & \\
\hline & & & \\
\hline & & & \\
\hline & & & \\
\hline & -0.7 & & \\
\hline & -0.9 & & \\
\hline & & & \\
\hline & & & \\
\hline & & & \\
\hline & & & \\
\hline & & & \\
\hline & & & \\
\hline & & & \\
\hline & & & \\
\hline & & & \\
\hline & -0 . & & \\
\hline & & & \\
\hline & & & \\
\hline & & & \\
\hline & & & \\
\hline & -0. & & \\
\hline & -1.0 & & \\
\hline & & & \\
\hline & & & \\
\hline & & & \\
\hline & & & \\
\hline & & & \\
\hline & & & \\
\hline & & & \\
\hline & & & \\
\hline & & & \\
\hline & & & \\
\hline & & & \\
\hline & & & \\
\hline & & & \\
\hline & & & \\
\hline & & & \\
\hline & & & \\
\hline & & & \\
\hline & & & \\
\hline & & & \\
\hline & & & \\
\hline & -3.2 & & \\
\hline & & & \\
\hline & & & \\
\hline & $5.1004 / 0$ & -5.204375 & \\
\hline
\end{tabular}

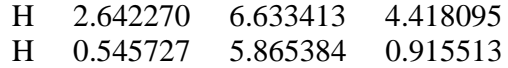

Table S9. RC structure coordinates of AfEST.

C $\quad 66.944210 \quad 46.325720 \quad 62.705490$

$\begin{array}{llll}\text { O } & 66.920792 & 46.828309 & 63.770950\end{array}$

$\begin{array}{llll}\mathrm{N} & 67.958744 & 45.525533 & 62.244090\end{array}$

$\begin{array}{lllll}\mathrm{H} & 67.960949 & 45.283916 & 61.259016\end{array}$

C $\quad 69.188200 \quad 45.383459 \quad 63.022519$

H $\quad 69.698799 \quad 46.343245 \quad 63.153143$

$\mathrm{H} \quad 68.930921 \quad 44.999814 \quad 64.017613$

C $\quad 70.171138 \quad 44.433199 \quad 62.319759$

$\begin{array}{llll}\text { O } & 71.356511 & 44.723902 & 62.193028\end{array}$

$\begin{array}{llll}\mathrm{N} & 69.640087 & 43.256789 & 61.878470\end{array}$

$\mathrm{H} \quad 68.637910 \quad 43.175816 \quad 61.766980$

C $\quad 64.150355 \quad 43.909203 \quad 58.117803$

$\begin{array}{llll}\mathrm{H} & 63.597236 & 43.108862 & 57.603302\end{array}$

C $\quad 65.483376 \quad 44.097994 \quad 57.394315$

H $\quad 66.116196 \quad 43.201791 \quad 57.533806$

$\mathrm{H} \quad 65.265111 \quad 44.170440 \quad 56.320120$

$\begin{array}{llll}\text { O } & 66.156440 & 45.260857 & 57.840299\end{array}$

$\begin{array}{llll}\mathrm{H} & 66.581914 & 45.668009 & 57.040088\end{array}$

C $\quad 64.145261 \quad 43.524482 \quad 59.613280$

$\begin{array}{llll}\mathrm{O} & 63.284166 & 43.963826 & 60.364183\end{array}$

$\begin{array}{lllll}\mathrm{N} & 65.046544 & 42.559406 & 60.045917\end{array}$

$\mathrm{H} \quad 65.965324 \quad 42.551930 \quad 59.610746$

C $\quad 65.494310 \quad 46.167780 \quad 49.028270$

$\begin{array}{llll}\mathrm{H} & 66.254933 & 46.919704 & 48.770280\end{array}$

$\mathrm{H} \quad 64.506383 \quad 46.604646 \quad 48.843462$

C $\quad 65.657045 \quad 45.794419 \quad 50.513741$

$\begin{array}{lllll}\mathrm{O} & 66.558688 & 44.912387 & 50.750277\end{array}$

$\begin{array}{llll}\text { O } & 64.971473 & 46.413472 & 51.347747\end{array}$

C $\quad 67.899780 \quad 47.616418 \quad 52.018850$

$\mathrm{H} \quad 68.450515 \quad 47.036042 \quad 51.269830$

$\begin{array}{llll}\mathrm{H} & 68.451175 & 48.537506 & 52.243297\end{array}$

C $\quad 67.691088 \quad 46.803975 \quad 53.267883$

$\begin{array}{llll}\mathrm{N} & 67.248076 & 45.506336 & 53.186930\end{array}$

$\begin{array}{llll}\mathrm{H} & 66.917237 & 45.091932 & 52.238337\end{array}$

C $\quad 67.084075 \quad 45.057320 \quad 54.445787$

$\begin{array}{llll}\mathrm{H} & 66.732412 & 44.058356 & 54.666726\end{array}$

$\begin{array}{llll}\mathrm{N} & 67.404946 & 45.971121 & 55.361737\end{array}$

C $\quad 67.790233 \quad 47.074843 \quad 54.618157$

$\mathrm{H} \quad 68.103536 \quad 47.994040 \quad 55.098049$

$\begin{array}{llll}\text { O } & 70.189237 & 42.509093 & 59.123989\end{array}$

$\begin{array}{llll}\text { O } & 68.078944 & 43.029594 & 59.473872\end{array}$

C $\quad 71.346927 \quad 45.209919 \quad 57.682729$

C $\quad 69.821774 \quad 45.337081 \quad 57.750850$

C $\quad 71.957202 \quad 44.195918 \quad 58.662224$

$\begin{array}{llll}\text { C } & 69.074963 & 44.004937 & 57.509700\end{array}$

$\begin{array}{llll}\text { C } & 71.453821 & 42.766178 & 58.464091\end{array}$

C $\quad 69.049946 \quad 43.152437 \quad 58.748316$

$\begin{array}{llll}\mathrm{H} & 71.622330 & 44.913227 & 56.659442\end{array}$

H $\quad 71.801269 \quad 46.193371 \quad 57.858430$

$\begin{array}{llll}\mathrm{H} & 69.467021 & 46.026216 & 56.977743\end{array}$

$\mathrm{H} \quad 69.512149 \quad 45.750455 \quad 58.720857$

H $\quad 73.046425 \quad 44.177464 \quad 58.518662$

$\begin{array}{llll}\mathrm{H} & 71.783201 & 44.484687 & 59.708010\end{array}$

$\begin{array}{llll}\mathrm{H} & 69.537673 & 43.470216 & 56.670891\end{array}$

H $\quad 68.044365 \quad 44.236295 \quad 57.264144$

H $\quad 71.365512 \quad 42.515224 \quad 57.399718$

$\begin{array}{llll}\mathrm{H} & 72.128565 & 42.048009 & 58.936127\end{array}$

H $\quad 66.131820 \quad 46.419032 \quad 61.953359$

H $\quad 70.169462 \quad 42.745763 \quad 61.181595$

$\begin{array}{llll}\mathrm{H} & 63.560397 & 44.826173 & 58.039892\end{array}$

$\begin{array}{llll}\mathrm{H} & 65.063892 & 42.471397 & 61.055435\end{array}$

$\begin{array}{llll}\mathrm{H} & 65.656946 & 45.300158 & 48.376614\end{array}$

$\mathrm{H} \quad 66.923550 \quad 47.866344 \quad 51.586597$ 
Table S10. TS 1 structure coordinates of AfEST.

\begin{tabular}{|c|c|c|c|}
\hline & -4.554963 & 1.471615 & \\
\hline & -5.508538 & 1.976495 & \\
\hline & -4.614969 & & \\
\hline & -3.736628 & & \\
\hline & -5.874641 & & \\
\hline & & & \\
\hline & & & \\
\hline & & & \\
\hline & & & \\
\hline & & & \\
\hline & -4.009075 & & \\
\hline & -0.698259 & & \\
\hline & & & \\
\hline & & & \\
\hline & & & \\
\hline & & & \\
\hline & -0.0 & & \\
\hline & & & \\
\hline & & & \\
\hline & & & \\
\hline & -2.456835 & & \\
\hline & & & \\
\hline & & & \\
\hline & & & \\
\hline & & & \\
\hline & & & \\
\hline & & & \\
\hline & & & \\
\hline & & & \\
\hline & & & \\
\hline & & & \\
\hline & & & \\
\hline & & & \\
\hline & & & \\
\hline & & & \\
\hline & & & \\
\hline & & & \\
\hline & & & \\
\hline & & & \\
\hline & & & \\
\hline & & & \\
\hline & & & \\
\hline & & & \\
\hline & & & \\
\hline & & & \\
\hline & & & \\
\hline & & & \\
\hline & & & \\
\hline & & & \\
\hline & & & \\
\hline & & & \\
\hline & & & \\
\hline & & & \\
\hline & 2.21 & & \\
\hline & & & \\
\hline & & & \\
\hline & & & \\
\hline & -3.50 & & \\
\hline & -5.04 & -2.6 & \\
\hline & & & \\
\hline & -3.253526 & & \\
\hline & & -0.112799 & \\
\hline & 6.163834 & -0.321064 & 2.27432 \\
\hline
\end{tabular}

Table S11. INT-1 structure coordinates of AfEST.

$\begin{array}{llll}\text { C } & 57.338372 & 35.564358 & 39.366536\end{array}$

$\begin{array}{llll}\text { O } & 57.414224 & 34.364468 & 39.613676\end{array}$
N $\quad 58.324365 \quad 36.359202 \quad 38.893563$

$\begin{array}{llll}\mathrm{H} & 58.127477 & 37.361926 & 38.742733\end{array}$

$\begin{array}{llll}\text { C } & 59.653054 & 35.857582 & 38.594351\end{array}$

$\begin{array}{llll}\mathrm{H} & 60.366838 & 36.162237 & 39.377041\end{array}$

H $\quad 59.616438 \quad 34.766486 \quad 38.596709$

C $\quad 60.276182 \quad 36.292491 \quad 37.255511$

$\begin{array}{llll}\mathrm{O} & 61.144827 & 35.589776 & 36.741702\end{array}$

$\begin{array}{llll}\mathrm{N} & 59.873710 & 37.480567 & 36.737699\end{array}$

H $\quad 59.204409 \quad 38.119246 \quad 37.201049$

C $\quad 55.425116 \quad 40.803657 \quad 39.232426$

$\begin{array}{llll}\mathrm{H} & 56.070938 & 41.688383 & 39.197221\end{array}$

C $\quad 56.187096 \quad 39.677826 \quad 39.974758$

H $\quad 55.758083 \quad 39.547352 \quad 40.973678$

H $\quad 56.091992 \quad 38.730035 \quad 39.434291$

$\begin{array}{llll}\text { O } & 57.573710 & 39.927188 & 40.233057\end{array}$

C $\quad 54.949896 \quad 40.540761 \quad 37.780469$

$\begin{array}{llll}\text { O } & 53.935064 & 41.103074 & 37.368219\end{array}$

$\begin{array}{llll}\text { O } & 58.381392 & 41.255214 & 38.608075\end{array}$

$\begin{array}{llll}\text { O } & 58.078226 & 39.006196 & 38.163257\end{array}$

$\begin{array}{llll}\text { C } & 61.426678 & 41.429744 & 38.816644\end{array}$

$\begin{array}{llll}\text { C } & 60.775972 & 40.745318 & 40.033269\end{array}$

$\begin{array}{llll}\text { C } & 60.476429 & 42.305271 & 37.989111\end{array}$

$\begin{array}{llll}\text { C } & 59.877789 & 39.557873 & 39.650920\end{array}$

$\begin{array}{llll}\text { C } & 59.221502 & 41.575042 & 37.509486\end{array}$

$\begin{array}{llll}\text { C } & 58.468140 & 39.881449 & 39.073368\end{array}$

H $\quad 62.264329 \quad 42.053477 \quad 39.159110$

$\begin{array}{llll}\mathrm{H} & 61.856448 & 40.649748 & 38.169120\end{array}$

$\begin{array}{llll}\mathrm{H} & 60.217102 & 41.487251 & 40.612729\end{array}$

H $\quad 61.579176 \quad 40.368311 \quad 40.682361$

H $\quad 60.150764 \quad 43.161839 \quad 38.595197$

$\begin{array}{llll}\mathrm{H} & 61.014710 & 42.707598 & 37.117200\end{array}$

$\begin{array}{llll}\mathrm{H} & 59.719561 & 38.901100 & 40.514482\end{array}$

H $\quad 60.402008 \quad 38.962392 \quad 38.894142$

$\mathrm{H} \quad 58.643403 \quad 42.223956 \quad 36.838182$

$\begin{array}{llll}\mathrm{H} & 59.480096 & 40.665150 & 36.948318\end{array}$

$\begin{array}{llll}\mathrm{N} & 55.692260 & 39.691746 & 37.016072\end{array}$

H $\quad 56.634682 \quad 39.398988 \quad 37.332492$

C $\quad 57.865418 \quad 48.459200 \quad 44.735880$

H $\quad 56.939205 \quad 48.908818 \quad 44.358705$

$\begin{array}{llll}\mathrm{H} & 58.683460 & 49.182025 & 44.685526\end{array}$

C $\quad 58.213546 \quad 47.224186 \quad 43.928304$

$\begin{array}{llll}\text { O } & 57.203331 & 46.363512 & 43.910807\end{array}$

$\begin{array}{llll}\text { O } & 59.297162 & 47.061558 & 43.391156\end{array}$

C $\quad 59.693387 \quad 44.066729 \quad 44.653765$

H $\quad 60.109689 \quad 45.015260 \quad 44.298681$

$\begin{array}{llll}\mathrm{H} & 60.503908 & 43.424299 & 45.017000\end{array}$

C $\quad 58.936247 \quad 43.388704 \quad 43.546092$

$\begin{array}{llll}\mathrm{N} & 57.895144 & 44.028988 & 42.902111\end{array}$

$\begin{array}{llll}\mathrm{H} & 57.470742 & 45.496310 & 43.420885\end{array}$

C $\quad 57.452248 \quad 43.191992 \quad 41.977877$

H $\quad 56.645176 \quad 43.381950 \quad 41.283851$

$\begin{array}{llll}\mathrm{N} & 58.144385 & 42.033967 & 41.990466\end{array}$

H $\quad 57.989111 \quad 41.244334 \quad 41.338001$

C $\quad 59.096911 \quad 42.142936 \quad 42.984285$

H $\quad 59.796510 \quad 41.346517 \quad 43.189399$

$\begin{array}{llll}\mathrm{H} & 56.401529 & 36.140508 & 39.517291\end{array}$

$\begin{array}{llll}\mathrm{H} & 60.336732 & 37.766694 & 35.885648\end{array}$

H $\quad 54.515641 \quad 41.073849 \quad 39.779002$

H $\quad 55.426099 \quad 39.633579 \quad 36.042644$

H $\quad 57.684959 \quad 48.174214 \quad 45.779965$

H $\quad 59.028404 \quad 44.294726 \quad 45.497941$

Table S12. TS 2 structure coordinates of AfEST.

$\begin{array}{llll}\text { C } & -4.676389 & 0.729515 & 2.554958\end{array}$

$\begin{array}{llll}\text { O } & -5.637329 & 0.873909 & 3.298744\end{array}$

$\begin{array}{llll}\mathrm{N} & -4.698862 & 0.131035 & 1.335723\end{array}$

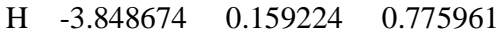

$\begin{array}{llll}\text { C } & -5.924822 & -0.379038 & 0.745277\end{array}$ 


\begin{tabular}{|c|c|c|c|}
\hline H & -6.579710 & -0.715090 & 1.551485 \\
\hline $\mathrm{H}$ & -6.470884 & 0.417886 & 0.217277 \\
\hline $\mathrm{C}$ & -5.796046 & -1.542165 & -0.251545 \\
\hline $\mathrm{O}$ & -6.802258 & -2.190118 & -0.525023 \\
\hline $\mathrm{N}$ & -4.591976 & -1.768978 & -0.840977 \\
\hline $\mathrm{H}$ & -3.730544 & -1.251016 & -0.665582 \\
\hline C & -0.977104 & 2.971604 & -0.109247 \\
\hline $\mathrm{H}$ & -0.085980 & 2.484754 & -0.520971 \\
\hline C & -1.526816 & 2.085313 & 1.019658 \\
\hline $\mathrm{H}$ & -1.309957 & 2.542628 & 1.987542 \\
\hline $\mathrm{H}$ & -2.609419 & 1.967657 & 0.935503 \\
\hline $\mathrm{O}$ & -0.907094 & 0.785920 & 1.138835 \\
\hline $\mathrm{C}$ & -1.906596 & 3.305167 & -1.298441 \\
\hline $\mathrm{O}$ & -1.850126 & 4.410873 & -1.828490 \\
\hline $\mathrm{O}$ & 0.040506 & 0.064706 & -1.086545 \\
\hline $\mathrm{O}$ & -2.381726 & -0.106268 & -0.344217 \\
\hline $\mathrm{C}$ & -0.763855 & -2.829615 & -1.429593 \\
\hline $\mathrm{C}$ & -0.233561 & -2.632810 & 0.006703 \\
\hline $\mathrm{C}$ & -0.052061 & -1.968071 & -2.486456 \\
\hline $\mathrm{C}$ & -0.911276 & -1.574989 & 0.900027 \\
\hline$C$ & -0.293358 & -0.462022 & -2.351331 \\
\hline $\mathrm{C}$ & -1.316243 & -0.219485 & 0.319514 \\
\hline $\mathrm{H}$ & -0.616736 & -3.882911 & -1.703613 \\
\hline $\mathrm{H}$ & -1.847176 & -2.655663 & -1.467743 \\
\hline $\mathrm{H}$ & 0.838870 & -2.420774 & -0.045939 \\
\hline $\mathrm{H}$ & -0.323823 & -3.582382 & 0.551080 \\
\hline $\mathrm{H}$ & 1.026921 & -2.170576 & -2.434945 \\
\hline $\mathrm{H}$ & -0.378501 & -2.277323 & -3.490879 \\
\hline $\mathrm{H}$ & -0.273874 & -1.392330 & 1.770224 \\
\hline $\mathrm{H}$ & -1.856372 & -1.982826 & 1.285320 \\
\hline $\mathrm{H}$ & 0.274024 & 0.074414 & -3.129493 \\
\hline $\mathrm{H}$ & -1.355044 & -0.244968 & -2.530738 \\
\hline $\mathrm{N}$ & -2.759927 & 2.328453 & -1.730206 \\
\hline $\mathrm{H}$ & -2.693799 & 1.376501 & -1.371838 \\
\hline $\mathrm{C}$ & 8.861129 & 1.011313 & 0.668716 \\
\hline $\mathrm{H}$ & 9.204025 & 1.695365 & -0.115091 \\
\hline $\mathrm{H}$ & 9.708628 & 0.455782 & 1.081644 \\
\hline $\mathrm{C}$ & 7.782734 & 0.063166 & 0.139669 \\
\hline $\mathrm{O}$ & 6.930876 & 0.634549 & -0.639657 \\
\hline $\mathrm{O}$ & 7.762944 & -1.115560 & 0.530616 \\
\hline $\mathrm{C}$ & 5.051871 & -0.904026 & 2.155791 \\
\hline $\mathrm{H}$ & 5.962050 & -1.392166 & 1.793617 \\
\hline $\mathrm{H}$ & 4.545677 & -1.546307 & 2.884912 \\
\hline $\mathrm{C}$ & 4.136985 & -0.588995 & 1.015949 \\
\hline $\mathrm{N}$ & 4.598522 & -0.182183 & -0.217679 \\
\hline $\mathrm{H}$ & 5.687423 & 0.068884 & -0.479875 \\
\hline $\mathrm{C}$ & 3.529994 & 0.047581 & -0.990485 \\
\hline $\mathrm{H}$ & 3.591838 & 0.390371 & -2.013721 \\
\hline $\mathrm{N}$ & 2.392723 & -0.196566 & -0.337391 \\
\hline $\mathrm{H}$ & 1.170217 & -0.073040 & -0.765627 \\
\hline $\mathrm{C}$ & 2.764744 & -0.596323 & 0.928509 \\
\hline $\mathrm{H}$ & 2.030970 & -0.841972 & 1.682514 \\
\hline $\mathrm{H}$ & -3.658471 & 1.067694 & 2.829483 \\
\hline $\mathrm{H}$ & -4.574463 & -2.519295 & -1.517735 \\
\hline $\mathrm{H}$ & -0.668401 & 3.942358 & 0.286590 \\
\hline $\mathrm{H}$ & -3.279070 & 2.525212 & -2.573780 \\
\hline $\mathrm{H}$ & 8.428317 & 1.627899 & 1.467564 \\
\hline $\mathrm{H}$ & 5.366252 & 0.008874 & 2.680427 \\
\hline
\end{tabular}

Table S13. EAM structure coordinates of AfEST.
C $\quad 78.693724 \quad 64.836252 \quad 51.791343$
$\begin{array}{llll}\mathrm{O} & 78.870095 & 65.681180 & 50.928370\end{array}$
$\begin{array}{llll}\mathrm{N} & 79.550580 & 64.536460 & 52.809366\end{array}$
H $\quad 79.309548 \quad 63.755638 \quad 53.408834$
C $80.859196 \quad 65.159446 \quad 52.931112$
H $\quad 81.651814 \quad 64.457616 \quad 52.629909$
H $\quad 80.887946 \quad 65.997933 \quad 52.233225$
C $\quad 81.265991 \quad 65.705862 \quad 54.309964$

$\begin{array}{llll}\text { O } & 82.140237 & 66.561149 & 54.379684\end{array}$

N $\quad 80.670250 \quad 65.162634 \quad 55.406310$

$\begin{array}{llll}\mathrm{H} & 80.013397 & 64.387863 & 55.370185\end{array}$

C $\quad 75.088761 \quad 62.131979 \quad 55.023900$

$\begin{array}{llll}\mathrm{H} & 74.576141 & 61.482285 & 55.740934\end{array}$

C $76.449506 \quad 61.541874 \quad 54.664754$

H $\quad 76.380739 \quad 60.517684 \quad 54.281222$

$\mathrm{H} \quad 76.983024 \quad 62.158825 \quad 53.938012$

$\begin{array}{llll}\text { O } & 77.273328 & 61.410880 & 55.867309\end{array}$

C $74.994431 \quad 63.557257 \quad 55.604828$

$\begin{array}{llll}\text { O } & 73.929525 & 63.951231 & 56.061018\end{array}$

$\begin{array}{llll}\text { O } & 81.725319 & 61.838871 & 61.377370\end{array}$

$\begin{array}{llll}\text { O } & 78.761536 & 62.942997 & 55.146989\end{array}$

C $\quad 79.379798 \quad 62.481395 \quad 59.694881$

C $\quad 78.485213 \quad 62.481023 \quad 58.447075$

C $79.796422 \quad 61.080293 \quad 60.159160$

C $\quad 79.159600 \quad 61.801055 \quad 57.232985$

$\begin{array}{llll}\text { C } & 80.517577 & 61.086557 & 61.502318\end{array}$

C $\quad 78.397511 \quad 62.096290 \quad 55.967636$

$\begin{array}{llll}\mathrm{H} & 80.282515 & 63.076006 & 59.507309\end{array}$

$\begin{array}{llll}\mathrm{H} & 78.837049 & 62.980821 & 60.510380\end{array}$

$\begin{array}{llll}\mathrm{H} & 78.231104 & 63.516775 & 58.184190\end{array}$

$\mathrm{H} \quad 77.539983 \quad 61.965113 \quad 58.655577$

H $\quad 78.907129 \quad 60.440880 \quad 60.255010$

$\begin{array}{llll}\mathrm{H} & 80.450439 & 60.611911 & 59.412839\end{array}$

H $\quad 79.203192 \quad 60.718152 \quad 57.384662$

$\begin{array}{llll}\mathrm{H} & 80.177427 & 62.184236 & 57.103778\end{array}$

H $\quad 79.857186 \quad 61.532841 \quad 62.266265$

$\begin{array}{llll}\mathrm{H} & 80.731844 & 60.049678 & 61.808461\end{array}$

$\begin{array}{llll}\mathrm{H} & 82.158625 & 61.835768 & 62.243218\end{array}$

$\begin{array}{llll}\mathrm{N} & 76.108868 & 64.351838 & 55.585127\end{array}$

H $\quad 76.984045 \quad 64.078389 \quad 55.155617$

C $75.425352 \quad 52.157413 \quad 55.565328$

H $\quad 75.540605 \quad 52.014252 \quad 54.481118$

$\begin{array}{llll}\mathrm{H} & 74.376607 & 51.983991 & 55.833488\end{array}$

C $75.867427 \quad 53.593274 \quad 55.934174$

$\begin{array}{llll}\text { O } & 74.997942 & 54.439449 & 56.202084\end{array}$

O $77.136186 \quad 53.777980 \quad 55.884115$

C $78.721138 \quad 54.758966 \quad 53.236375$

H $\quad 78.235280 \quad 53.964705 \quad 53.814452$

H $\quad 79.808610 \quad 54.663976 \quad 53.376760$

C $78.204433 \quad 56.092845 \quad 53.718282$

$\begin{array}{llll}\mathrm{N} & 77.551265 & 56.187114 & 54.924229\end{array}$

$\mathrm{H} \quad 77.323535 \quad 55.320289 \quad 55.509346$

$\begin{array}{llll}\text { C } & 77.186986 & 57.478865 & 55.086402\end{array}$

H $\quad 76.628373 \quad 57.811614 \quad 55.952067$

N $\quad 77.568715 \quad 58.252440 \quad 54.074237$

C $\quad 78.207969 \quad 57.380121 \quad 53.211129$

H $\quad 78.629673 \quad 57.725870 \quad 52.273491$

$\begin{array}{llll}\mathrm{H} & 77.776781 & 64.214061 & 51.841682\end{array}$

$\begin{array}{llll}\mathrm{H} & 81.010163 & 65.476360 & 56.304832\end{array}$

H $\quad 74.474873 \quad 62.126151 \quad 54.113548$

H $\quad 75.992224 \quad 65.307634 \quad 55.891356$

H $\quad 76.068659 \quad 51.416485 \quad 56.057833$

H $\quad 78.513499 \quad 54.615886 \quad 52.167597$

Table S14. EAM with a 6-HCA structure coordinates of AfEST.

$\begin{array}{llll}\mathrm{C} & 49.669596 & 67.358502 & 48.973059 \\ \mathrm{O} & 49.629670 & 67.971150 & 47.883804 \\ \mathrm{~N} & 49.412023 & 67.979768 & 50.121134 \\ \mathrm{H} & 49.308841 & 67.392214 & 50.937048 \\ \mathrm{C} & 49.141613 & 69.432931 & 50.263500 \\ \mathrm{H} & 48.504217 & 69.778572 & 49.447332 \\ \mathrm{H} & 48.542158 & 69.478725 & 51.173510 \\ \mathrm{C} & 50.303326 & 70.345964 & 50.362669 \\ \mathrm{O} & 50.135388 & 71.466355 & 50.817147 \\ \mathrm{~N} & 51.493195 & 69.834952 & 50.109757\end{array}$




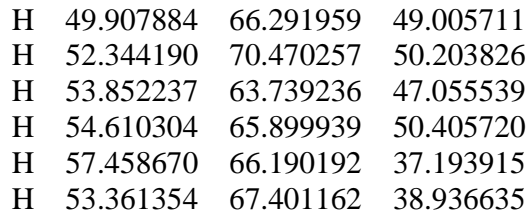

Table S15. INT-2 structure coordinates of AfEST.

C $42.293242 \quad 50.904493 \quad 54.326212$

$\begin{array}{llll}\mathrm{O} & 42.362180 & 49.731934 & 54.614506\end{array}$

$\mathrm{N} \quad 41.175123 \quad 51.683769 \quad 54.346620$

$\mathrm{H} \quad 41.197558 \quad 52.628518 \quad 53.945982$

C $39.865053 \quad 51.135321 \quad 54.662515$

H $39.270856 \quad 51.028579 \quad 53.740648$

H $40.005936 \quad 50.145066 \quad 55.096392$

C $39.036495 \quad 51.966044 \quad 55.657666$

O $38.409266 \quad 51.424556 \quad 56.563171$

$\mathrm{N} \quad 39.013975 \quad 53.303143 \quad 55.421183$

H $\quad 39.453650 \quad 53.725168 \quad 54.589295$

C $\quad 43.681952 \quad 55.407232 \quad 51.622096$

H $\quad 43.542652 \quad 56.219962 \quad 50.900608$

C $\quad 42.702780 \quad 54.277235 \quad 51.333948$

$\begin{array}{llll}\mathrm{H} & 43.029319 & 53.707487 & 50.448955\end{array}$

$\mathrm{H} \quad 42.688469 \quad 53.588461 \quad 52.189111$

$\begin{array}{llll}\mathrm{O} & 41.410730 & 54.815319 & 51.099390\end{array}$

C $\quad 43.625255 \quad 56.065954 \quad 53.055486$

$\begin{array}{llll}\mathrm{O} & 44.467440 & 56.924076 & 53.310771\end{array}$

$\begin{array}{lllll}\text { O } & 43.642404 & 48.873316 & 49.399026\end{array}$

$\begin{array}{llll}\text { O } & 39.184497 & 54.853564 & 51.201827\end{array}$

$\begin{array}{llll}\text { C } & 40.482388 & 51.004365 & 49.433797\end{array}$

C $\quad 40.188362 \quad 52.452854 \quad 49.842957$

C $\quad 41.940544 \quad 50.611218 \quad 49.688124$

C $\quad 40.233596 \quad 52.673033 \quad 51.355623$

$\begin{array}{llll}\text { C } & 42.276633 & 49.212921 & 49.183055\end{array}$

C $\quad 40.334346 \quad 54.146062 \quad 51.814748$

$\begin{array}{llll}\mathrm{H} & 39.814661 & 50.315027 & 49.973192\end{array}$

$\mathrm{H} \quad 40.266730 \quad 50.880680 \quad 48.362300$

H $\quad 39.209470 \quad 52.754799 \quad 49.456400$

H $\quad 40.918065 \quad 53.113695 \quad 49.362864$

$\begin{array}{llll}\mathrm{H} & 42.608572 & 51.333059 & 49.199009\end{array}$

$\mathrm{H} \quad 42.160259 \quad 50.652743 \quad 50.765081$

$\begin{array}{llll}\mathrm{H} & 41.093869 & 52.149590 & 51.781946\end{array}$

$\begin{array}{llll}\mathrm{H} & 39.344866 & 52.241383 & 51.833140\end{array}$

$\begin{array}{llll}\mathrm{H} & 41.603140 & 48.474201 & 49.652538\end{array}$

$\begin{array}{llll}\mathrm{H} & 42.122568 & 49.154932 & 48.098979\end{array}$

H $\quad 43.796887 \quad 48.946198 \quad 50.343708$

$\begin{array}{llll}\mathrm{O} & 40.434181 & 54.296146 & 53.109783\end{array}$

C $\quad 38.129646 \quad 55.256446 \quad 52.057402$

$\mathrm{H} \quad 38.540134 \quad 55.702140 \quad 52.970253$

$\begin{array}{llll}\mathrm{H} & 37.585328 & 56.029202 & 51.498120\end{array}$

C $37.177493 \quad 54.109518 \quad 52.411218$

$\begin{array}{llll}\mathrm{H} & 36.324003 & 54.533904 & 52.962343\end{array}$

C $\quad 36.687329 \quad 53.331528 \quad 51.185682$

$\begin{array}{llll}\mathrm{H} & 37.552101 & 52.872152 & 50.701272\end{array}$

C $\quad 35.660950 \quad 52.243980 \quad 51.537357$

$\begin{array}{llll}\mathrm{H} & 36.254818 & 54.027990 & 50.450268\end{array}$

C $\quad 34.248652 \quad 52.815295 \quad 51.771316$

$\begin{array}{llll}\mathrm{H} & 35.985688 & 51.715002 & 52.442767\end{array}$

$\begin{array}{llll}\mathrm{H} & 35.591731 & 51.503818 & 50.731678\end{array}$

C $\quad 33.633107 \quad 53.233643 \quad 50.452789$

$\mathrm{H} \quad 34.272495 \quad 53.661128 \quad 52.464835$

$\mathrm{H} \quad 33.598572 \quad 52.039404 \quad 52.195323$

O $33.490446 \quad 52.509556 \quad 49.490766$

$\begin{array}{llll}\text { O } & 33.254588 & 54.538677 & 50.434186\end{array}$

$\mathrm{H} \quad 32.900242 \quad 54.701198 \quad 49.556903$

$\begin{array}{llll}\mathrm{H} & 37.685052 & 53.421695 & 53.098347\end{array}$

$\begin{array}{llll}\mathrm{N} & 42.706235 & 55.646008 & 54.001045\end{array}$

$\begin{array}{llll}\mathrm{H} & 41.822721 & 55.201723 & 53.691863\end{array}$ 


$\begin{array}{llll}\text { C } & 41.632291 & 57.571045 & 42.558688 \\ \text { H } & 40.566887 & 57.330237 & 42.448639 \\ \text { H } & 42.174005 & 57.222131 & 41.675764 \\ \text { C } & 42.160141 & 56.880106 & 43.801019 \\ \text { O } & 42.866147 & 55.888344 & 43.772010 \\ \text { O } & 41.704800 & 57.474511 & 44.901662 \\ \text { C } & 40.282894 & 54.487019 & 45.099394 \\ \text { H } & 39.910687 & 55.252745 & 44.403326 \\ \text { H } & 39.631471 & 53.609062 & 45.014475 \\ \text { C } & 40.303626 & 54.993235 & 46.505217 \\ \text { N } & 41.279137 & 55.869085 & 46.947856 \\ \text { H } & 41.815474 & 56.868599 & 45.715055 \\ \text { C } & 41.005973 & 56.102905 & 48.222470 \\ \text { H } & 41.585983 & 56.716471 & 48.896351 \\ \text { N } & 39.898590 & 55.444031 & 48.620512 \\ \text { H } & 39.590649 & 55.335093 & 49.598457 \\ \text { C } & 39.444322 & 54.722696 & 47.540457 \\ \text { H } & 38.583422 & 54.074949 & 47.608519 \\ \text { H } & 43.177540 & 51.497172 & 54.007949 \\ \text { H } & 38.427429 & 53.865701 & 56.021647 \\ \text { H } & 44.714626 & 55.053630 & 51.515336 \\ \text { H } & 42.687836 & 56.234370 & 54.824290 \\ \text { H } & 41.713387 & 58.659534 & 42.654461 \\ \text { H } & 41.292779 & 54.225347 & 44.769573\end{array}$

Table S16. PC structure coordinates of AfEST.
$\begin{array}{llll}\text { C } & 41.678230 & 42.261493 & 19.157696\end{array}$
$\begin{array}{llll}\text { O } & 41.847747 & 43.434557 & 19.505759\end{array}$
$\begin{array}{llll}\mathrm{N} & 42.182675 & 41.721023 & 18.031837\end{array}$
H $\quad 41.932503 \quad 40.767534 \quad 17.811341$
C $43.075256 \quad 42.445044 \quad 17.118179$
$\mathrm{H} \quad 43.850166 \quad 42.940198 \quad 17.700178$
$\begin{array}{llll}\mathrm{H} & 43.532579 & 41.716733 & 16.447982\end{array}$
C $\quad 42.344643 \quad 43.484639 \quad 16.247003$
$\begin{array}{llll}\text { O } & 42.034826 & 43.258007 & 15.085179\end{array}$
$\begin{array}{llll}\mathrm{N} & 42.109463 & 44.659071 & 16.891125\end{array}$
H $\quad 42.190066 \quad 44.693706 \quad 17.902784$
C $\quad 41.875073 \quad 45.468296 \quad 23.032884$
$\begin{array}{llll}\mathrm{H} & 42.340103 & 46.183994 & 23.718252\end{array}$
$\begin{array}{llll}\text { C } \quad 42.950248 & 44.819338 & 22.151893\end{array}$
$\mathrm{H} \quad 43.739122 \quad 44.424570 \quad 22.812242$
$\begin{array}{llll}\mathrm{H} & 42.530297 & 43.979140 & 21.591429\end{array}$
$\begin{array}{llll}\text { O } & 43.487808 & 45.734910 & 21.218785\end{array}$
H $\quad 44.183281 \quad 46.237036 \quad 21.737625$
C $\quad 40.781145 \quad 46.248495 \quad 22.293641$
$\begin{array}{llll}\text { O } & 40.301320 & 47.277457 & 22.753505\end{array}$
$\begin{array}{llll}\mathrm{N} & 40.300137 & 45.685483 & 21.134590\end{array}$
$\begin{array}{llll}\mathrm{H} & 40.875868 & 45.025883 & 20.621575\end{array}$
$\begin{array}{llll}\text { C } & 49.053809 & 49.140772 & 28.310492\end{array}$
$\begin{array}{llll}\mathrm{H} & 49.969108 & 49.330925 & 27.731020\end{array}$
$\begin{array}{llll}\mathrm{H} & 49.317460 & 48.539748 & 29.188157\end{array}$
$\begin{array}{llll}\text { C } \quad 48.040412 & 48.389686 & 27.413267\end{array}$
$\begin{array}{llll}\text { O } & 47.419379 & 49.132202 & 26.577778\end{array}$
$\begin{array}{llll}\text { O } & 47.954550 & 47.151792 & 27.540904\end{array}$
C $48.791022 \quad 46.848474 \quad 24.488344$
H $\quad 49.289034 \quad 47.823153 \quad 24.391358$

$\begin{array}{llll}\mathrm{H} & 49.365041 & 46.106743 & 23.918859\end{array}$

C $\quad 47.388869 \quad 46.912923 \quad 23.982426$

$\begin{array}{llll}\mathrm{N} & 46.443903 & 47.702000 & 24.590354\end{array}$

$\begin{array}{llll}\mathrm{H} & 46.686669 & 48.287925 & 25.466426\end{array}$

C $45.293241 \quad 47.553701 \quad 23.898130$

H $\quad 44.376986 \quad 48.067681 \quad 24.157883$

$\begin{array}{llll}\mathrm{N} & 45.428442 & 46.713822 & 22.875054\end{array}$

$\begin{array}{llll}\text { C } & 46.746613 & 46.305164 & 22.928038\end{array}$

$\begin{array}{llll}\mathrm{H} & 47.155710 & 45.603704 & 22.212783\end{array}$

$\begin{array}{llll}\text { O } & 45.487759 & 40.549838 & 21.610277\end{array}$

$\begin{array}{llll}\text { O } & 46.735273 & 46.264080 & 16.487529\end{array}$

$\begin{array}{llll}\text { C } & 45.425570 & 43.747876 & 19.589309\end{array}$

$\begin{array}{llll}\text { C } & 46.066696 & 45.132596 & 19.562048\end{array}$

$\begin{array}{llll}\text { C } & 45.855172 & 42.852698 & 20.752147\end{array}$

$\begin{array}{llll}\text { C } & 45.445072 & 46.024101 & 18.462088\end{array}$

$\begin{array}{llll}\text { C } & 45.018657 & 41.571868 & 20.735520\end{array}$

$\begin{array}{llll}\text { C } & 45.778368 & 45.510529 & 17.084361\end{array}$

$\begin{array}{llll}\mathrm{H} & 45.645211 & 43.224705 & 18.650282\end{array}$

$\begin{array}{llll}\mathrm{H} & 44.341207 & 43.895808 & 19.646741\end{array}$

$\mathrm{H} \quad 45.877958 \quad 45.631989 \quad 20.512309$

$\begin{array}{llll}\mathrm{H} & 47.155514 & 45.063780 & 19.423213\end{array}$

H $\quad 46.918312 \quad 42.585678 \quad 20.674317$

$\begin{array}{llll}\mathrm{H} & 45.712997 & 43.383158 & 21.705019\end{array}$

$\begin{array}{llll}\mathrm{H} & 44.358359 & 46.006227 & 18.596459\end{array}$

$\mathrm{H} \quad 45.799263 \quad 47.053669 \quad 18.566834$

$\begin{array}{llll}\mathrm{H} & 43.967797 & 41.831230 & 20.951270\end{array}$

H $\quad 45.045925 \quad 41.129628 \quad 19.731342$

$\begin{array}{llll}\mathrm{H} & 45.541681 & 40.948100 & 22.496399\end{array}$

$\begin{array}{llll}\text { O } & 45.314893 & 44.517274 & 16.555481\end{array}$

$\begin{array}{llll}\text { C } & 47.187278 & 45.799798 & 15.202685\end{array}$

$\begin{array}{llll}\mathrm{H} & 47.441020 & 44.735461 & 15.269997\end{array}$

$\begin{array}{llll}\mathrm{H} & 46.373231 & 45.898059 & 14.474230\end{array}$

$\begin{array}{llll}\text { C } & 48.397218 & 46.635567 & 14.824102\end{array}$

$\mathrm{H} \quad 49.129640 \quad 46.556800 \quad 15.637052$

$\begin{array}{llll}\text { C } & 49.016359 & 46.174311 & 13.499879\end{array}$

$\mathrm{H} \quad 49.290272 \quad 45.111284 \quad 13.578950$

C $\quad 50.252933 \quad 46.984854 \quad 13.093766$

$\begin{array}{llll}\mathrm{H} & 48.263745 & 46.244254 & 12.702836\end{array}$

C $\quad 51.386834 \quad 46.868320 \quad 14.114133$

$\begin{array}{llll}\mathrm{H} & 49.987700 & 48.043122 & 12.975360\end{array}$

$\begin{array}{llll}\mathrm{H} & 50.626077 & 46.647574 & 12.120673\end{array}$

$\begin{array}{llll}\text { C } & 52.685374 & 47.508793 & 13.644302\end{array}$

H $\quad 51.594788 \quad 45.808349 \quad 14.330718$

H $\quad 51.101551 \quad 47.322894 \quad 15.072706$

$\begin{array}{llll}\text { O } & 52.886236 & 47.941993 & 12.537843\end{array}$

$\begin{array}{llll}\text { O } & 53.671984 & 47.554766 & 14.584074\end{array}$

H $\quad 53.346612 \quad 47.183780 \quad 15.422663$

H $\quad 48.108694 \quad 47.693139 \quad 14.756020$

$\mathrm{H} \quad 41.076532 \quad 41.553224 \quad 19.753231$

H $44.536066 \quad 45.343956 \quad 16.417542$

$\begin{array}{llll}\mathrm{H} & 41.383487 & 44.697998 & 23.647683\end{array}$

H $\quad 39.702912 \quad 46.291553 \quad 20.587502$

H $\quad 48.656799 \quad 50.115588 \quad 28.620619$

H $48.791959 \quad 46.591908 \quad 25.554670$ 


\section{Supporting Information References}

(1) Morris, G. M.; Huey, R.; Lindstrom, W.; Sanner, M. F.; Belew, R. K.; Goodsell, D. S.; Olson, A. J. AutoDock4 and AutoDockTools4: Automated docking with selective receptor flexibility. J. Comput. Chem. 2009, 30, 2785-2791.

(2) Ryckaert, J. P.; Ciccotti, G.; Berendsen, H. J. C. Numerical integration of the cartesian equations of motion of a system with constraints: molecular dynamics of n-alkanes. J. Comput. Phys. 1977, 23, 327-341.

(3) Darden, T.; York, D.; Pedersen, L. Particle mesh Ewald: An N-log(N) method for Ewald sums in large systems. $J$. Chem. Phys. 1993, 98, 10089-10092.

(4) Carvalho, A. T. P.; Dourado, D. F. A. R.; Skvortsov, T.; de Abreu, M.; Ferguson, L. J.; Quinn, D. J.; Moody, T. S.; Huang, M. Catalytic Mechanism of Phenylacetone Monooxygenases for Non-Native Linear Substrates. Phys. Chem. Chem. Phys. 2017, 19, 26851-26861.

(5) Grimme, S.; Antony, J.; Ehrlich, S.; Krieg, H. A Consistent and Accurate Ab Initio Parametrization of Density Functional Dispersion Correction (DFT-D) for the 94 Elements H-Pu. J. Chem. Phys. 2010, 132, 154104. 